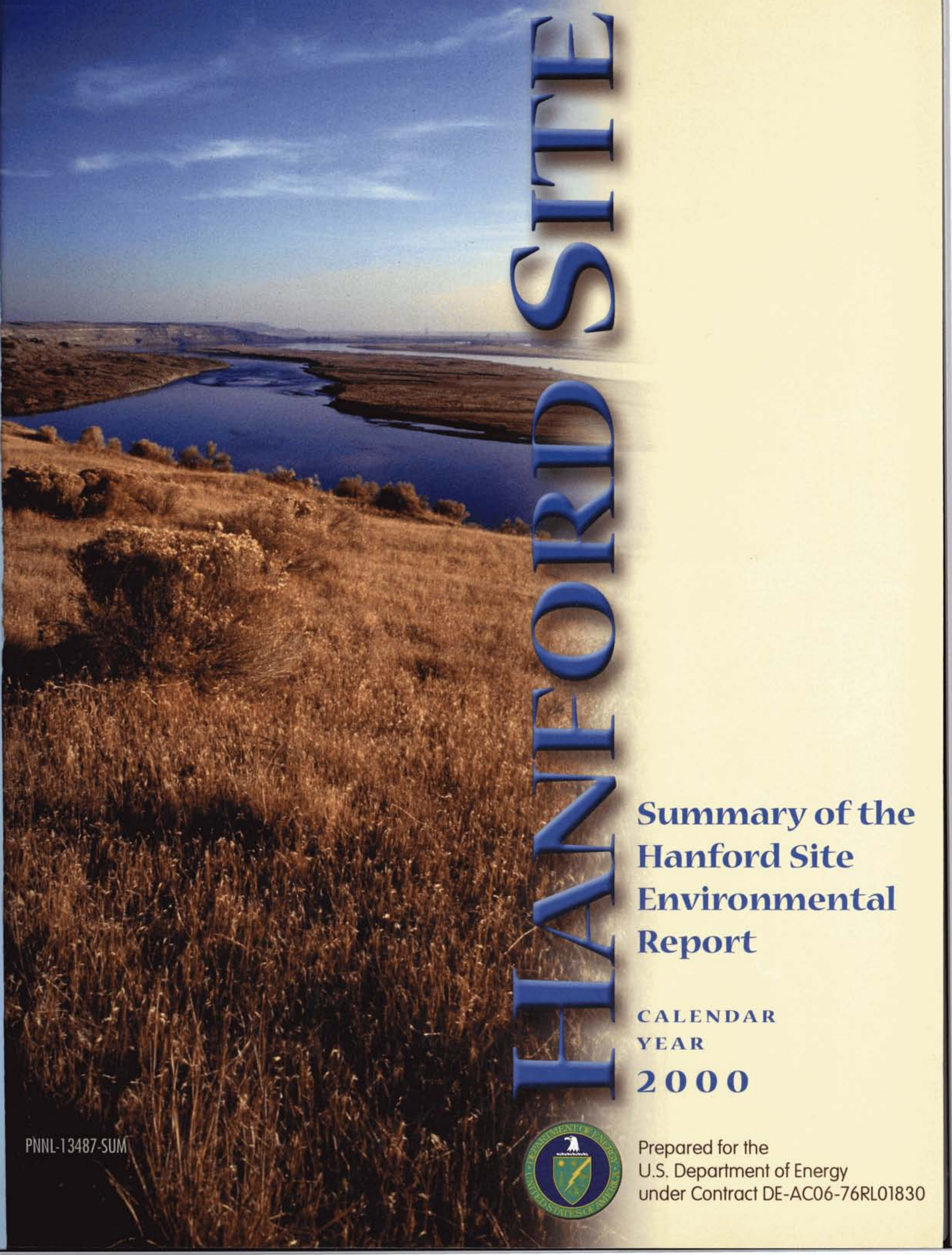




\section{Summary of the Hanford Site Environmental Report for Calendar Year 2000}

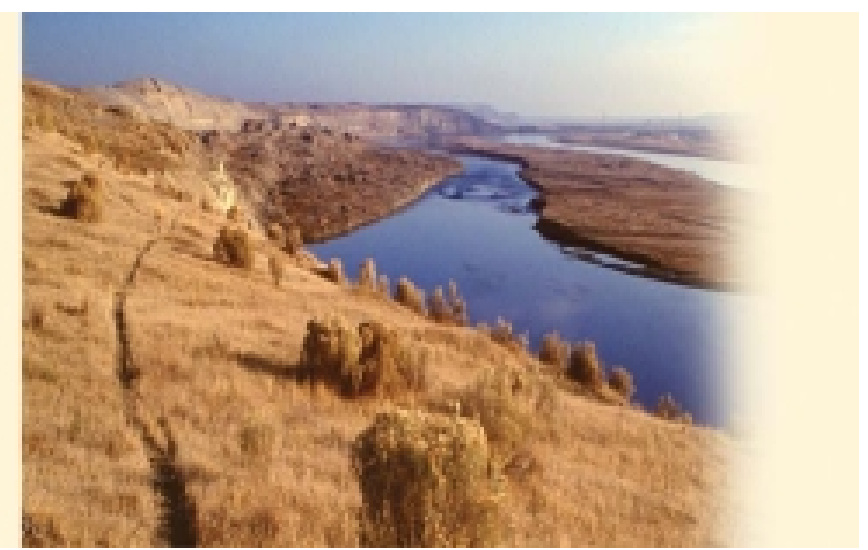

\section{Editors}

R. W. Hanf

L. F. Morasch

T. M. Poston

G. P. O'Connor

September 2001

Prepared for the U.S. Department of Energy by Pacific Northwest National Laboratory under contract DE-AC06-76RL01830, with contributions from CH2M HILL Hanford Group, Inc.; MACTEC-ERS; Fluor Hanford, Inc. and its affiliate companies; and Bechtel Hanford, Inc. and its subcontractors 


\section{Disclaimer}

This report was prepared as an account of work sponsored by an agency of the United States Government. Reference herein to any specific commercial product, process, or service by trade name, trademark, manufacturer, or otherwise does not necessarily constitute or imply its endorsement, recommendation, or favoring by the United States Government or any agency thereof, or Battelle Memorial Institute.

\section{Cover Photograph}

The cover photo is by L. E. Bowman and is used with permission. The photo is looking south from the Wahluke Slope over the Columbia River. The land in the immediate foreground of the photo is part of the Hanford Reach National Monument. The 100-F Area of the Hanford Site is in the distance on the west side of the river.

\section{Report Inquiries}

Inquiries about this booklet or comments and suggestions about its content may be directed to Mr. D. C. (Dana) Ward, Department of Energy, Richland Operations Office, Office of Site Services, P.O. Box 550, Richland, Washington 99352 (Dana_C_Ward@apimc01.rl.gov) or to Mr. T. M. (Ted) Poston, K6-75, Pacific Northwest National Laboratory, P.O. Box 999, Richland, Washington 99352 (ted.poston@pnl.gov).

Copies of this summary booklet and the 2000 report have been provided to many public libraries in communities around the Hanford Site and to several university libraries in Washington and Oregon. Copies also can be found at DOE's Public Reading Room located in the Consolidated Information Center, Room 101L, on the campus of Washington State University Tri-Cities. Copies of the 2000 report can be obtained from Mr. R. W. (Bill) Hanf, K6-75, Pacific Northwest National Laboratory, P.O. Box 999, Richland, Washington 99352 (bill.hanf@pnl.gov) while supplies last. The reports can be accessed on the Internet at http://hanford-site.pnl.gov/envreport or www.hanford.gov/docs/annualrp00/index.htm.

\section{Pacific Northwest National Laboratory}

Operated by Battelle for the U.S. Department of Energy under Contract DE- ACO6-762 01830

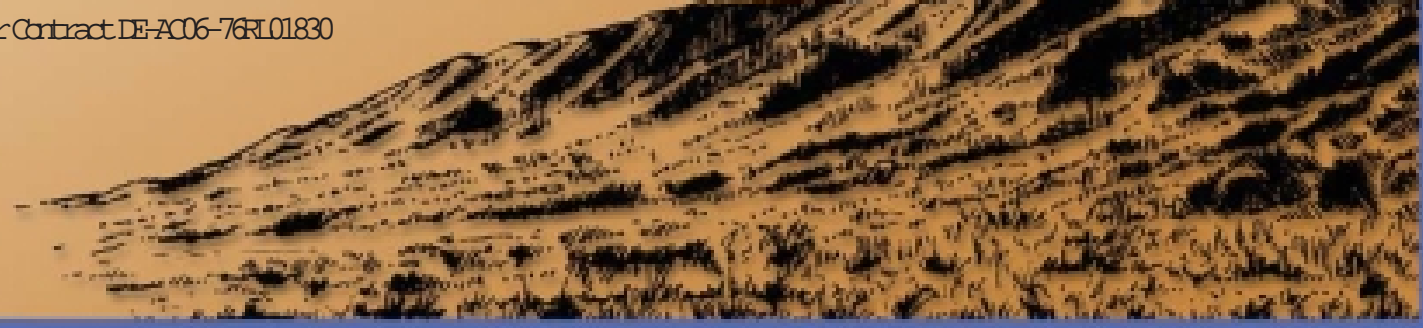




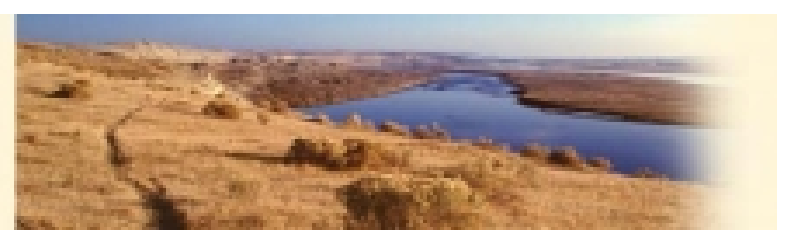

\section{contents}

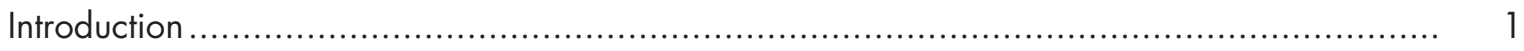

Overview of the Hanford Site and its Mission ................................................................. 2

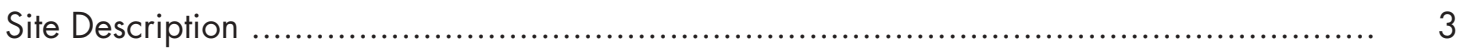

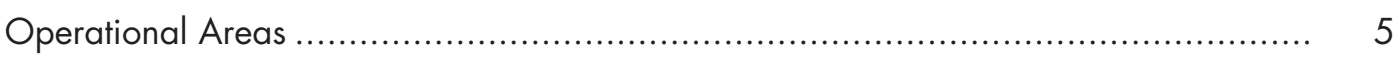

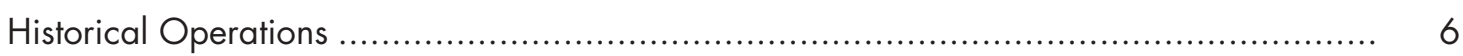

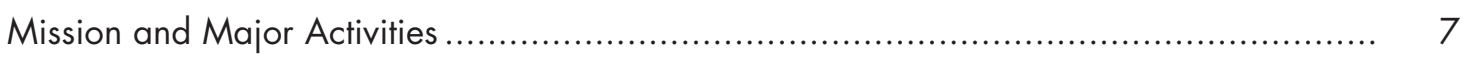

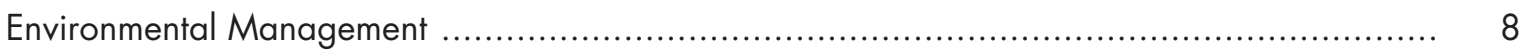

Waste Storage, Treatment, and Disposal ................................................. 9

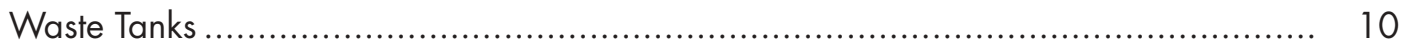

Immobilization of Waste Contained in Underground Tanks .............................. 11

Liquid Waste Management ................................................................... 12

Solid Waste Management............................................................ 13

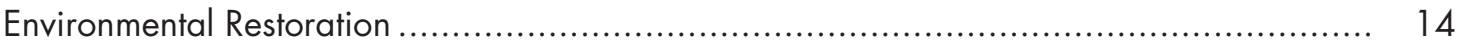

Environmental Restoration Disposal Facility ............................................ 14

Waste Site Remediation ............................................................ 14

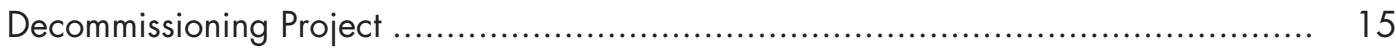

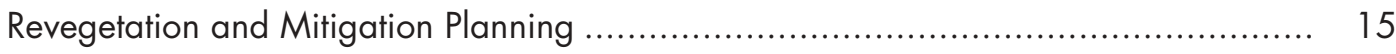

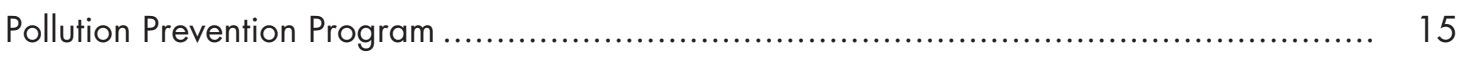

Compliance with Environmental Regulations ...................................................... 16

Hanford Federal Facility Agreement and Consent Order ................................. 18

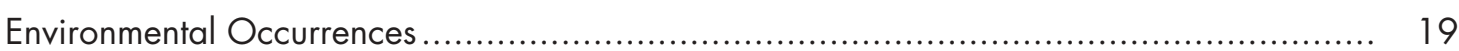

Potential Radiological Doses from 2000 Hanford Operations ................................... 20

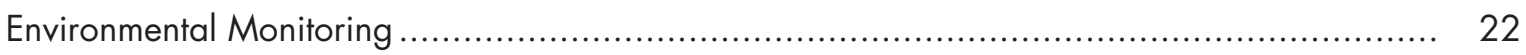

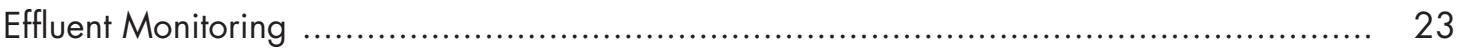

Liquid Effluents ...................................................................................... 23

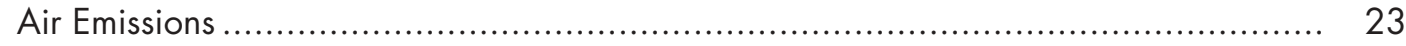

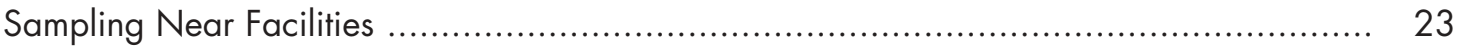

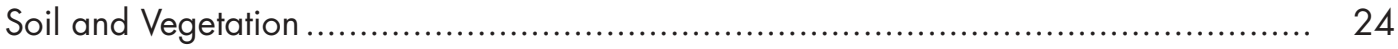

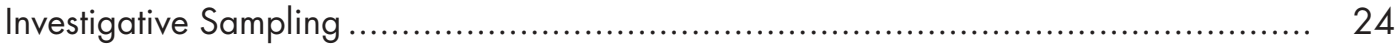

Environmental Surveillance Sampling Onsite and in Nearby/Distant Communities ........... 24 


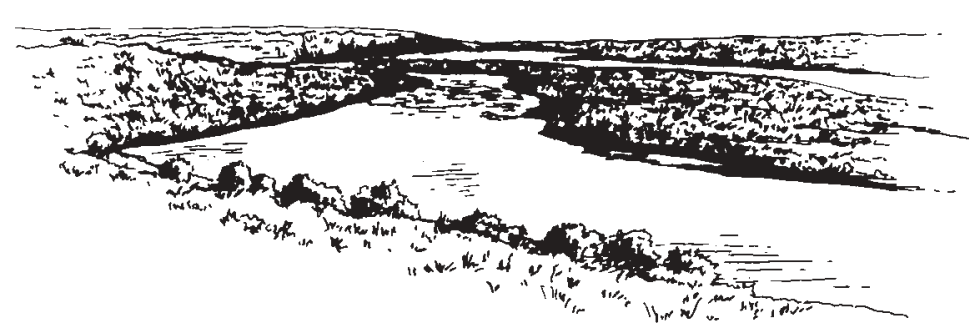

Surface Water, Sediment, and Drinking Water .......................................... 25

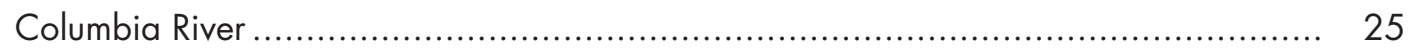

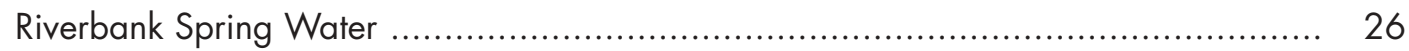

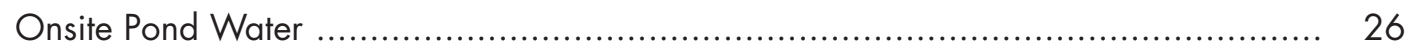

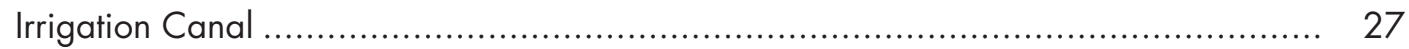

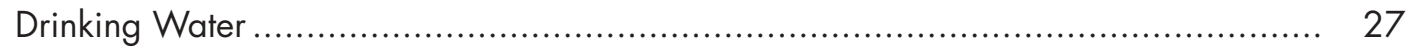

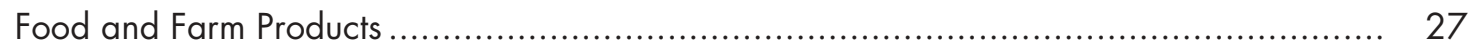

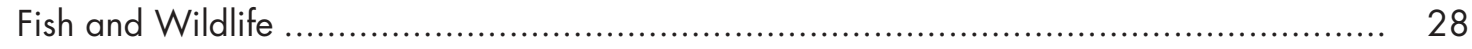

Radiological Surveys and External Radiation ............................................. 29

The 2000 Hanford Site Wildfire .................................................................. 30

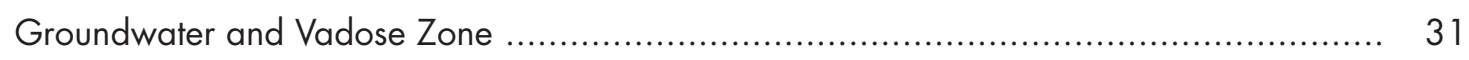

Groundwater Protection and Monitoring .................................................... 31

Vadose Zone Characterization ................................................................. 33

Vadose Zone Monitoring ..................................................................... 34

Vadose Zone Technical Demonstrations ...................................................... 35

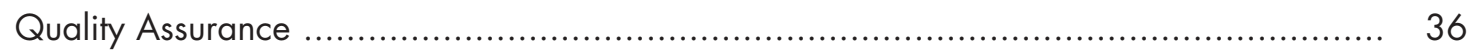

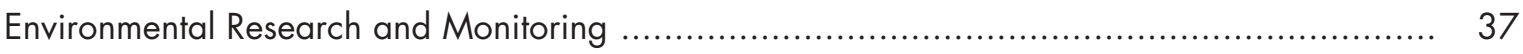

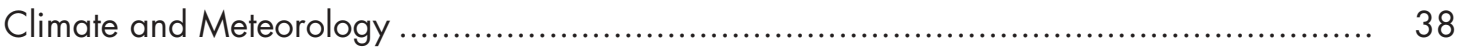

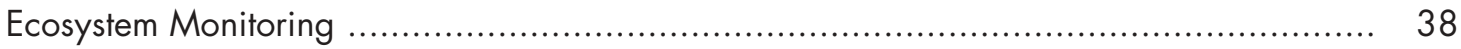

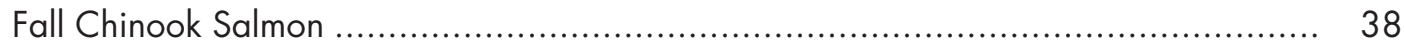

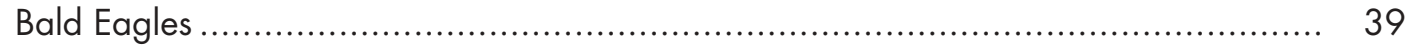

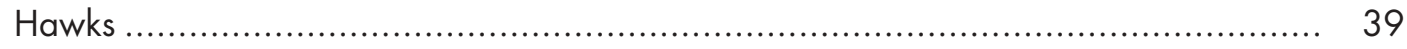

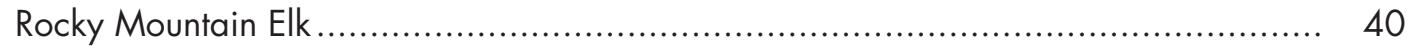

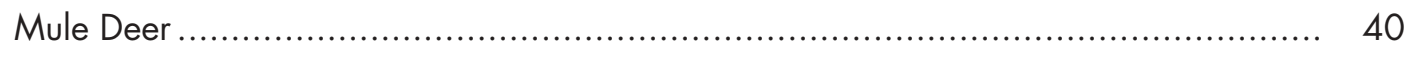

Plant Biodiversity Inventories ............................................................. 41

Ecological Compliance .............................................................. 42

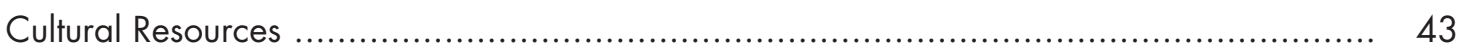

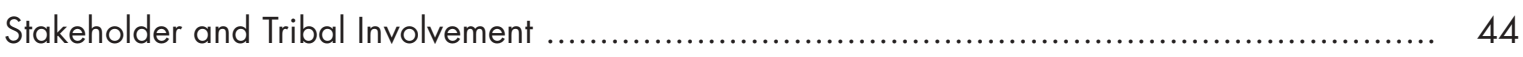

The Role of Indian Tribes ................................................................................ 45

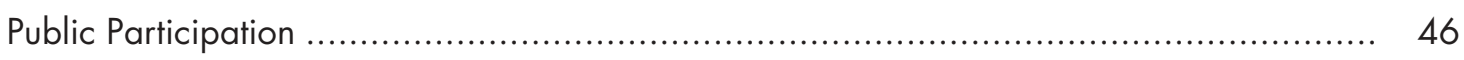

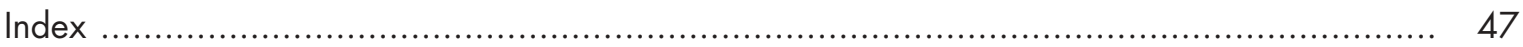



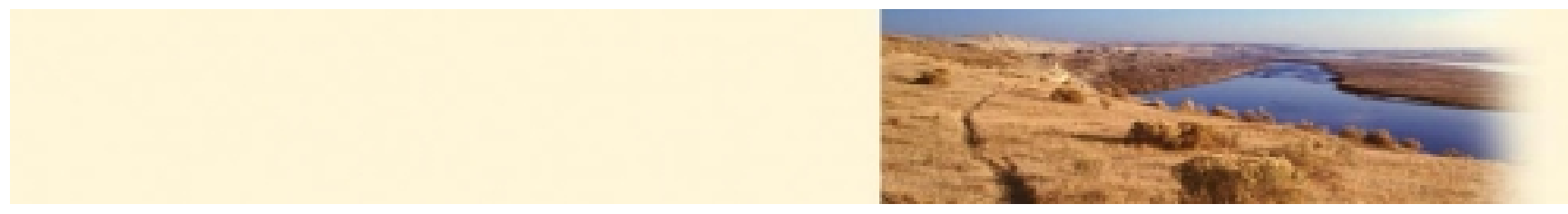

\section{Introduction}

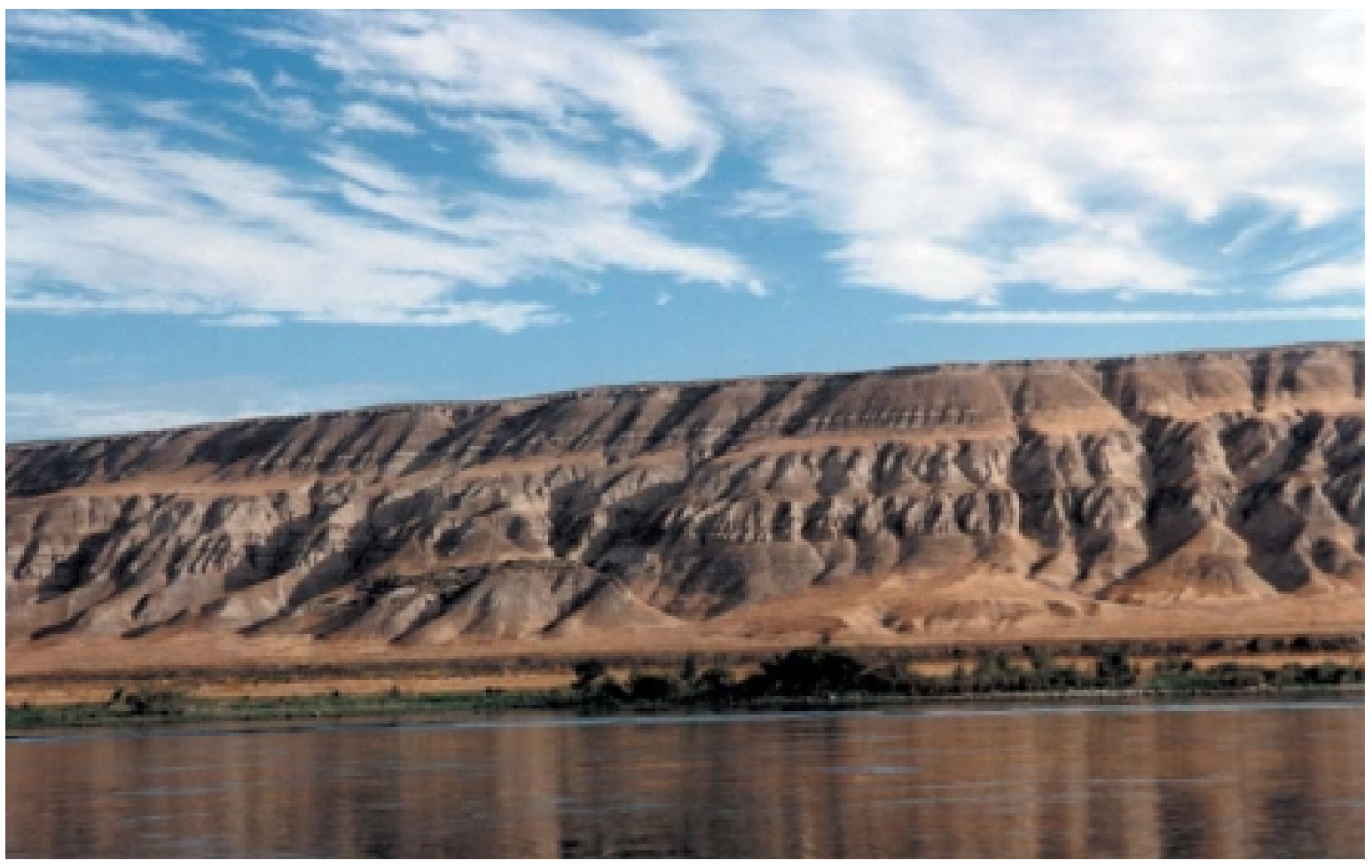

The White Bluffs stretch for 32 kilometers (20 miles) of the Hanford Reach north of Richland, Washington.

This booklet summarizes the Hanford Site Environmental Report for Calendar Year 2000. The Hanford Site environmental report is prepared annually to summarize environmental data and information, describe environmental management performance, demonstrate the status of compliance with environmental regulations, and highlight major environmental programs and efforts. The document is written to meet requirements and guidelines of the U.S. Department of Energy (DOE) and the needs of the public.

This summary booklet is designed to briefly 1) describe the Hanford Site and its mission; 2) describe environmental programs at the Hanford Site; 3) discuss estimated radionuclide exposures to the public from 2000 Hanford Site activities; 4) summarize the status of compliance with environmental regulations; and 5) present information on environmental monitoring and surveillance and groundwater protection and monitoring. Readers interested in more detailed information can consult the 2000 report or the technical documents cited and listed in that report. 


\section{Overview of the Hanford Site and its Mission}

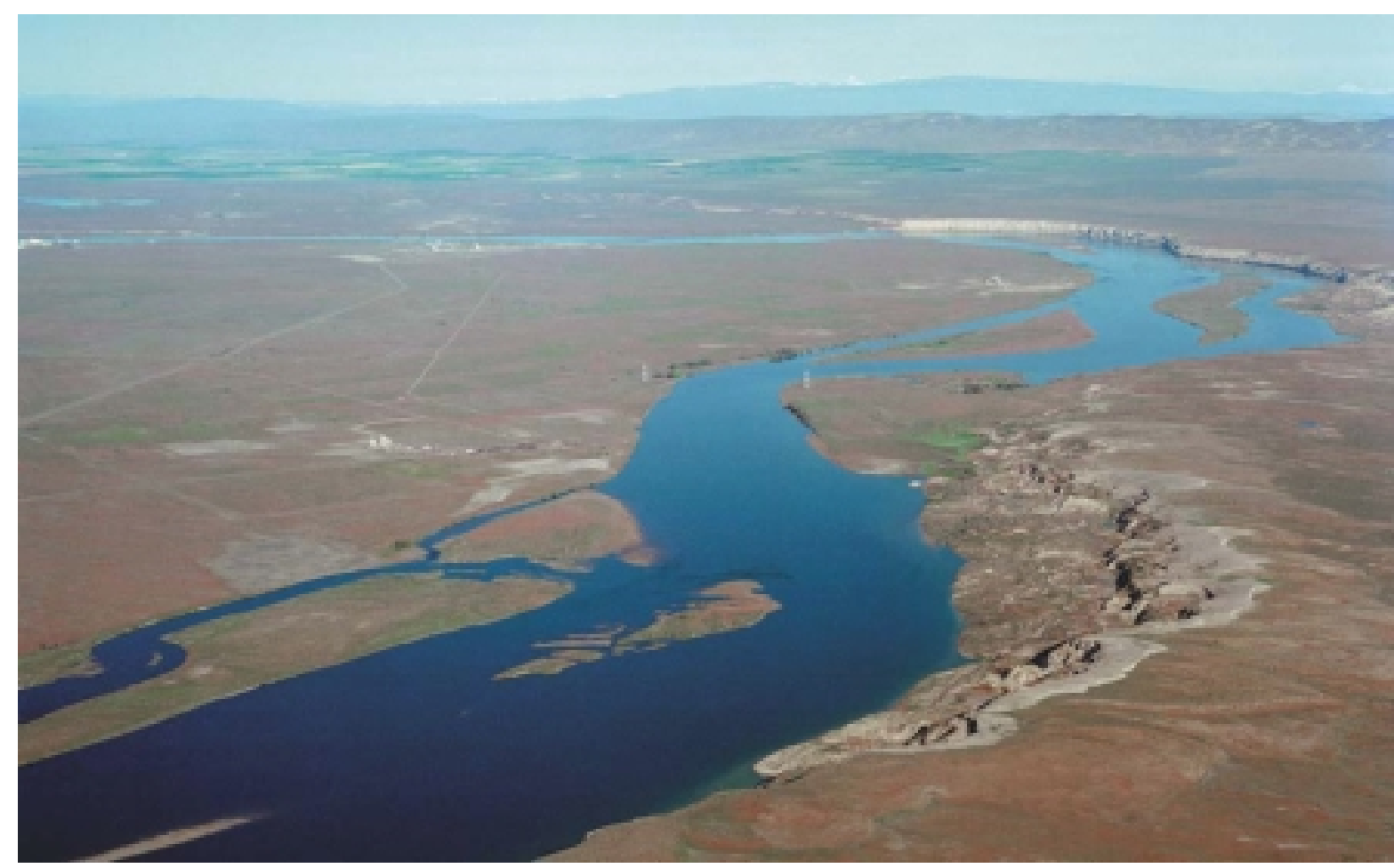

The mission of DOE's Office of River Protection is to clean up Hanford's radioactive tank waste, an action that is essential for protecting the Columbia River.

The Hanford Site lies within the semiarid Pasco Basin of the Columbia Plateau in southeastern Washington State. The site occupies an area of $\sim 1,517$ square kilometers ( $~ 586$ square miles) located north of the city of Richland and the confluence of the Yakima and Columbia Rivers.

This large area has restricted public access and provides a buffer for the smaller areas on the site that historically were used for production of nuclear materials, waste storage, and waste disposal. The Columbia River flows eastward through the northern part of the Hanford Site and then turns south, forming part of the eastern site boundary. The Yakima River flows near a portion of the southern boundary and joins the Columbia River at the city of Richland. Portions of the site are managed by the U.S. Fish and Wildlife Service as part of Hanford Reach National Monument/Saddle Mountain National Wildlife Refuge.

The cities of Richland, Kennewick, and Pasco (Tri-Cities) constitute the nearest population center and are located southeast of the site. Land in the surrounding environs is used for urban and industrial development, irrigated and dry-land farming, and grazing. 


\section{Site Description}

The Hanford Site was acquired by the federal government in 1943, and until the 1980s, was dedicated primarily to the production of plutonium for national defense and the management of resulting waste.

The site is a relatively large, undisturbed area of shrub-steppe that contains a rich, natural diversity of plant and animal species adapted to the region's semiarid environment.

The entire site was designated a National Environmental Research Park (one of four nationally) by the former U.S. Energy Research and Development Administration, a precursor to DOE. In 2000, the biodiversity of the Hanford Site was recognized as a national asset when portions of the site were designated the Hanford Reach National Monument.

Terrestrial vegetation on the site consists of 10 major plant communities:

- $\quad$ sagebrush/bluebunch wheatgrass

- $\quad$ sagebrush/cheatgrass or sagebrush/Sandberg's bluegrass

- $\quad$ sagebrush-bitterbrush/cheatgrass

- greasewood/cheatgrass-saltgrass

- $\quad$ winterfat/Sandberg's bluegrass

- $\quad$ thyme buckwheat/Sandberg's bluegrass

- cheatgrass-tumble mustard

- willow or riparian

- $\quad$ spiny hopsage

- $\quad$ sand dunes.

Over 600 species of plants have been identified on the site, and recent work by The Nature Conservancy of Washington has further delineated 30 distinct plant community types from within the 10 major communities.

There are two types of natural aquatic habitats on the Hanford Site. One is the Columbia
River and associated wetlands, and the second is upland aquatic sites. The upland sites include small spring streams and seeps located mainly on the Fitzner/Eberhardt Arid Lands Ecology Reserve on Rattlesnake Mountain (e.g., Rattlesnake Springs, Dry Creek, Snively Springs) and West Lake, a small, natural pond near the 200 Areas.

More than 1,000 species of insects, 17 species of reptiles and amphibians, 44 species of fish, 258 species of birds, and 42 species of mammals have been found on the Hanford Site. Deer and elk are the major large mammals. A herd of Rocky Mountain elk has inhabited the site since 1972. There were 747 elk at the end of the 1999 hunting season. Coyotes also are plentiful on the site. The Great Basin pocket mouse is the most abundant mammal on the site.

Waterfowl are numerous on the Columbia River, and the bald eagle is a regular winter visitor along the river. Salmon and steelhead are the fish species of most interest to sport fishermen and are commonly consumed by local Native American tribes. Fall chinook salmon spawn in the Hanford Reach, the most important natural spawning area in the mainstem Columbia River.

Although no Hanford Site plant species have been identified from the federal list of threatened and endangered species, biodiversity inventory work conducted in collaboration with The Nature Conservancy of Washington identified 127 populations of 30 different rare plant taxa.

Several species of mammals, birds, mollusks, reptiles, and invertebrates occurring on the site are candidates for formal listing under the Endangered Species Act. The U.S. Fish and Wildlife Service lists the bald eagle as threatened. The bald eagle is a common winter resident and has initiated nesting on the site but has never successfully produced offspring. 


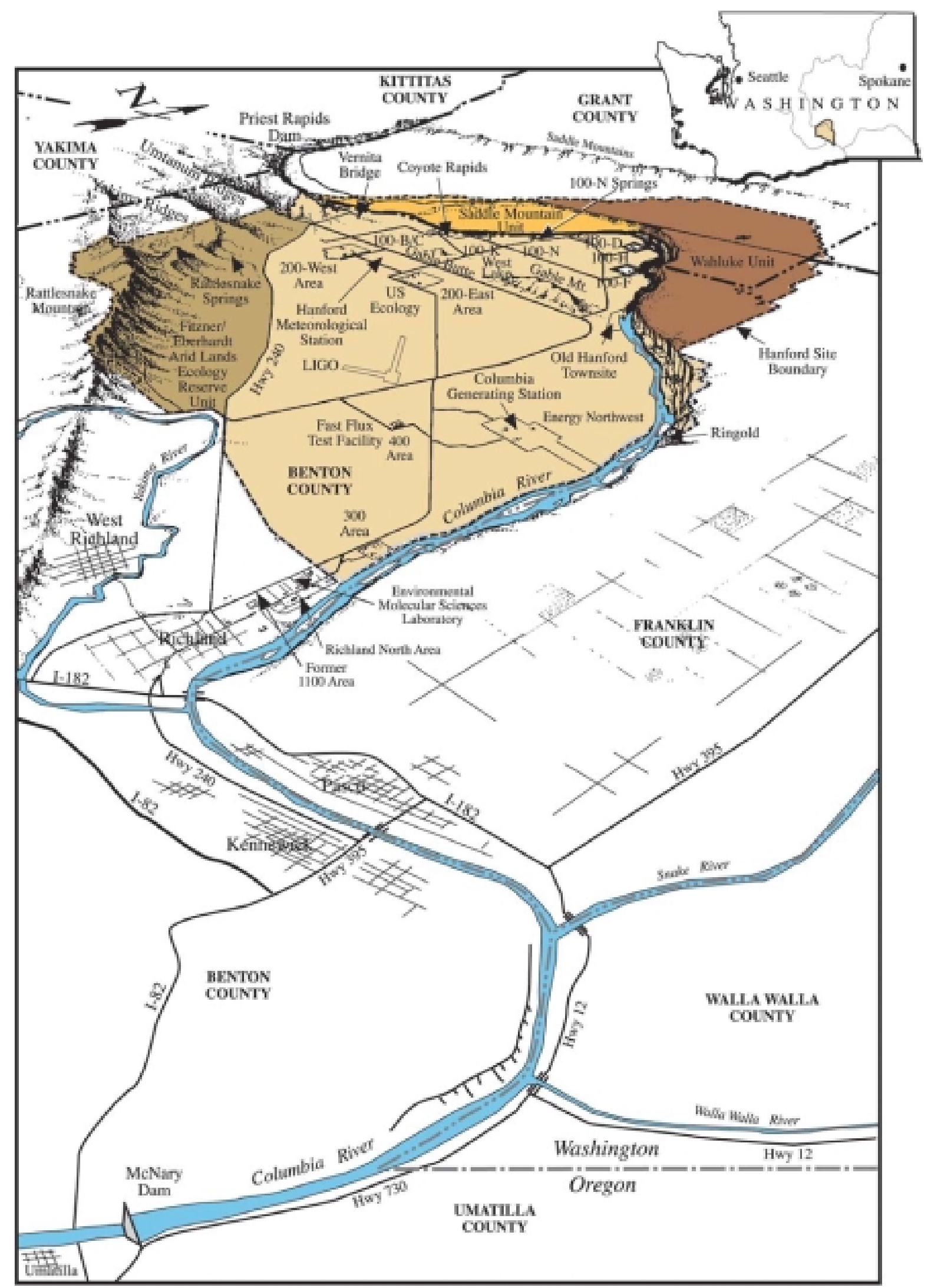

The Hanford Site and surrounding area. 


\section{Operational Areas}

For security, safety, and functional reasons, the site is divided into operational areas, as shown on the previous page:

- The 100 Areas, on the south shore of the Columbia River, are the sites of nine retired plutonium production reactors $(100-\mathrm{B}, 100-\mathrm{C}, 100-\mathrm{D}$, 100-DR, 100-F, 100-H, 100-KW, $100-\mathrm{KE}, 100-\mathrm{N})$ that occupy 11 square kilometers (4 square miles).

- The 200-West and 200-East Areas are located on a plateau and are $\sim 8$ and 11 kilometers (5 and 7 miles) south and west of the Columbia River. The 200 Areas cover 16 square kilometers (6.2 square miles).

- The 300 Area is located just north of Richland. This area covers 1.5 square kilometers (0.6 square mile).

- The 400 Area is $\sim 8$ kilometers (5 miles) northwest of the 300 Area.

This area covers 0.61 square kilometers $(0.23$ square miles).

- The 600 Area includes all the Hanford Site not occupied by the 100, 200, 300, and 400 Areas.

- The former 311-hectare (768-acre) 1100 Area is located between the 300 Area and Richland and included site support services such as general stores and transportation maintenance. This area was transferred to the Port of Benton and is no longer part of the site. DOE contractors continue to lease facilities in this area.

- The Richland North Area (off the site) includes DOE and its contractor facilities, mostly leased office buildings, generally located in the northern part of the city of Richland.

The Fitzner/Eberhardt Arid Lands Ecology Reserve was established in 1967 by the U.S. Atomic Energy Commission to preserve shrub-steppe habitat and vegetation. In 1971, the reserve was classified a Research Natural Area as a result of a federal interagency cooperative agreement. In June
1997, DOE transferred management, including access management, of the reserve from Pacific Northwest National Laboratory to the U.S. Fish and Wildlife Service, which will continue to operate the reserve using an in-place policy until a new management plan can be written.

In June 2000, the Hanford Reach National Monument was established by Presidential Proclamation to protect the nation's only free-flowing stretch of the Columbia River above Bonneville Dam, and the largest remnant of the shrub-steppe ecosystem once blanketing the Columbia Basin. The monument includes the Fitzner/Eberhardt Arid Lands Ecology Reserve Unit, McGee RanchRiverlands Unit, Saddle Mountain Unit, Wahluke Unit, and a Columbia River Islands Unit. These areas have served as a safety and security buffer zone for Hanford Site operations since 1943. DOE and the U.S. Fish and Wildlife Service are joint stewards of the monument. 


\section{Historical Operations}

The Hanford Site was established in 1943 to use technology developed at the University of Chicago and the Clinton Laboratory in Oak Ridge, Tennessee, to produce plutonium for some of the nuclear weapons tested and used in World War II. Hanford was the first plutonium production facility in the world.

Hanford Site operations have produced liquid, solid, and gaseous waste. Most waste resulting from site operations has had at least the potential to contain radioactive materials. Radioactive waste originally was categorized as "high level," "intermediate level," or "low level," which referred to the level of radioactivity present. Some high-level solid waste, such as large pieces of machinery and equipment, were placed onto railroad flatcars and stored in under- ground tunnels. Both intermediate- and low-level solid waste, consisting of tools, machinery, paper, and wood were placed into covered trenches at storage and disposal sites known as "burial grounds."

High-level liquid waste was stored in large underground tanks. Intermediate-level liquid waste streams were usually routed to underground structures of various types called "cribs." Occasionally, trenches were filled with the liquid waste and then covered with soil after the waste had soaked into the ground. Low-level liquid waste streams were usually routed to ditches and ponds. Some liquid waste was discharged to the Columbia River. All unrestricted discharge of radioactive liquid waste to the ground was discontinued in 1997.

\section{Hanford at a Glance}

Location

Dominant Feature

Size

Employees

Mission

Budget

Site Management

Prime Contractors
The U.S. Department of Energy's Hanford Site is located in southeastern Washington State near the city of Richland.

Rattlesnake Mountain on the Fitzner/Eberhardt Arid Lands Ecology (ALE) Reserve rises 1,074 meters (3,525 feet) above the Columbia River Plain.

The site covers approximately 1,517 square kilometers (586 square miles).

DOE and its contractors employed $\sim 11,000$ workers in fiscal year 2000.

Hanford's mission is to safely clean up and manage the site's legacy wastes and develop and deploy science and technology.

The annual budget is approximately $\$ 1.4$ billion.

\section{DOE Richland Operations Office and DOE Office of River Protection}

Fluor Hanford, Inc. (nuclear legacy cleanup), Battelle Memorial Institute operates Pacific Northwest National Laboratory (research and development), Bechtel Hanford, Inc. (environmental restoration), Hanford Environmental Health Foundation loccupational and environmental health services), CH2M HILL Hanford Group, Inc. (storing, retrieving and characterizing waste stored in 177 underground tanks), MACTEC-ERS (tank farm vadose zone characterization), and Bechtel-Washington (design, license, construct, and operate a vitrification facility to separate, treat, and immobilize radioactive liquid waste and sludges stored in the underground tanks at Hanford). 


\section{Mission and Major Activities}

The DOE has two major missions on the Hanford Site: 1) environmental management, and 2) science and technology. The environmental management mission is to safely clean up and manage the site's legacy waste and includes the following:

- managing waste and handling, storing, treating, and disposing of radioactive, hazardous, mixed, or sanitary waste from past and current operations

- stabilizing facilities by transitioning them from an operating mode to a long-term surveillance and maintenance mode

- maintaining the Fast Flux Test Facility reactor and its associated support facilities while proceeding to permanent deactivation and shutdown of the facility

- maintaining and cleaning up several hundred inactive radioactive, hazardous, and mixed waste disposal sites; remediating contaminated groundwater; and surveillance, maintenance, and decommissioning of inactive facilities.

The science and technology mission is to develop and deploy science and technology in the service of the nation, and at the Hanford Site this includes the following:

- conducting research and development in energy, health, safety, environmental sciences, molecular sciences, environmental restoration, waste management, and national security

- developing new technologies for environmental restoration and waste management, including site characterization and assessment methods waste minimization, treatment, and remediation technology.

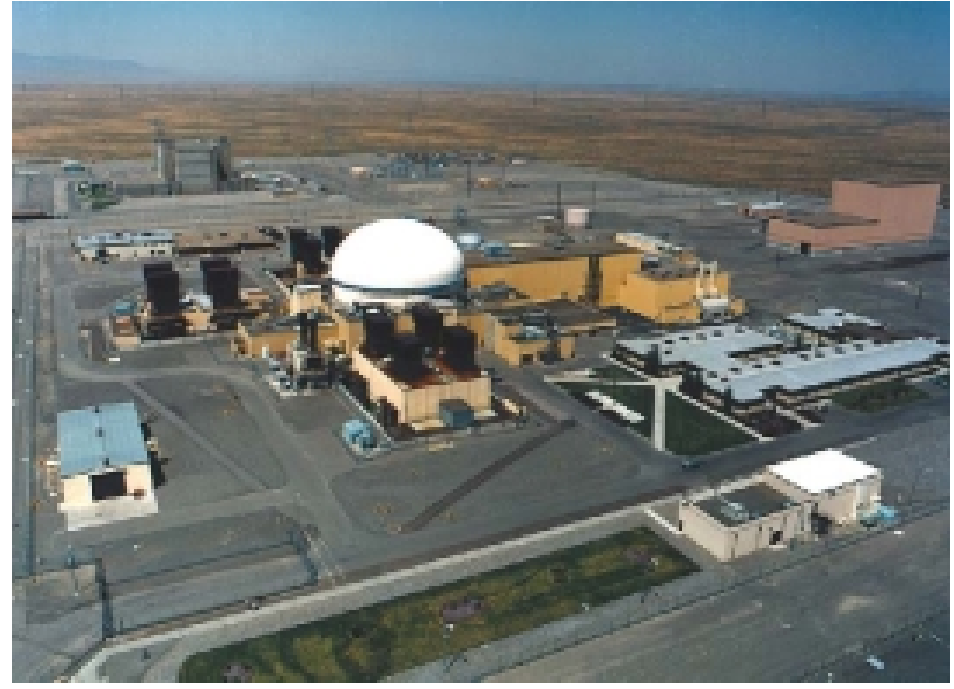

In 2000, DOE issued an environmental impact statement for the Fast Flux Test Facility. In January 2001, the Secretary of Energy determined the facility should be permanently deactivated; however, implementation of the ruling was postponed pending review. A detailed summary of the status of this facility is available at http://www.fftf.org/ currstat/.

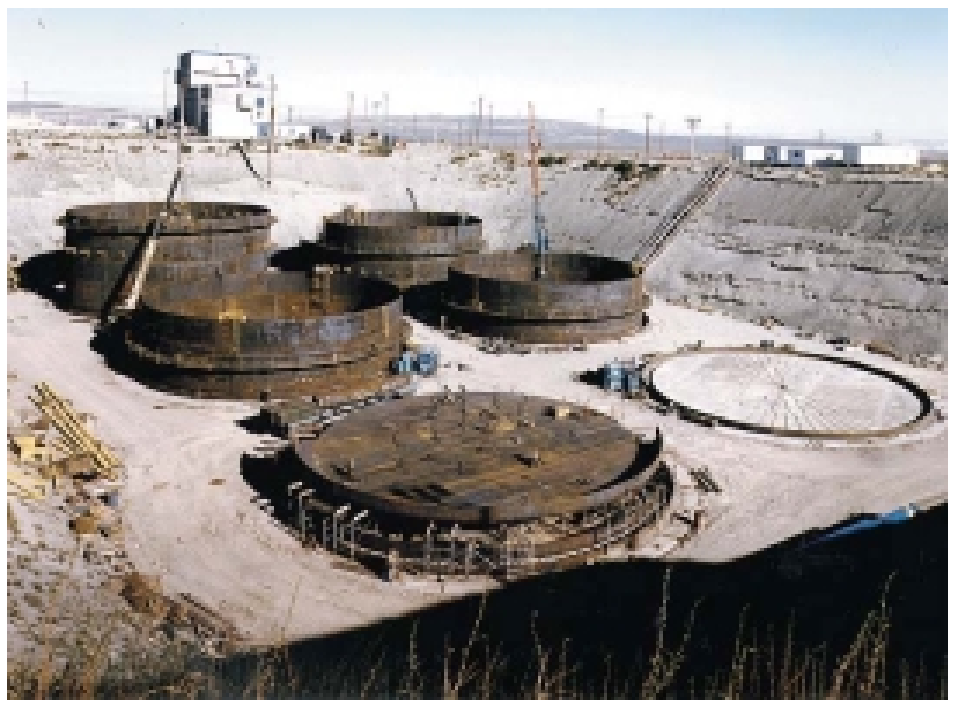

This historical photo shows construction of radioactive waste storage tanks. There were 177 tanks built at the Hanford Site between 1943 and 1985. A major focus of DOE's mission is to clean up the legacy waste stored in these tanks. 


\section{Environmental Management}

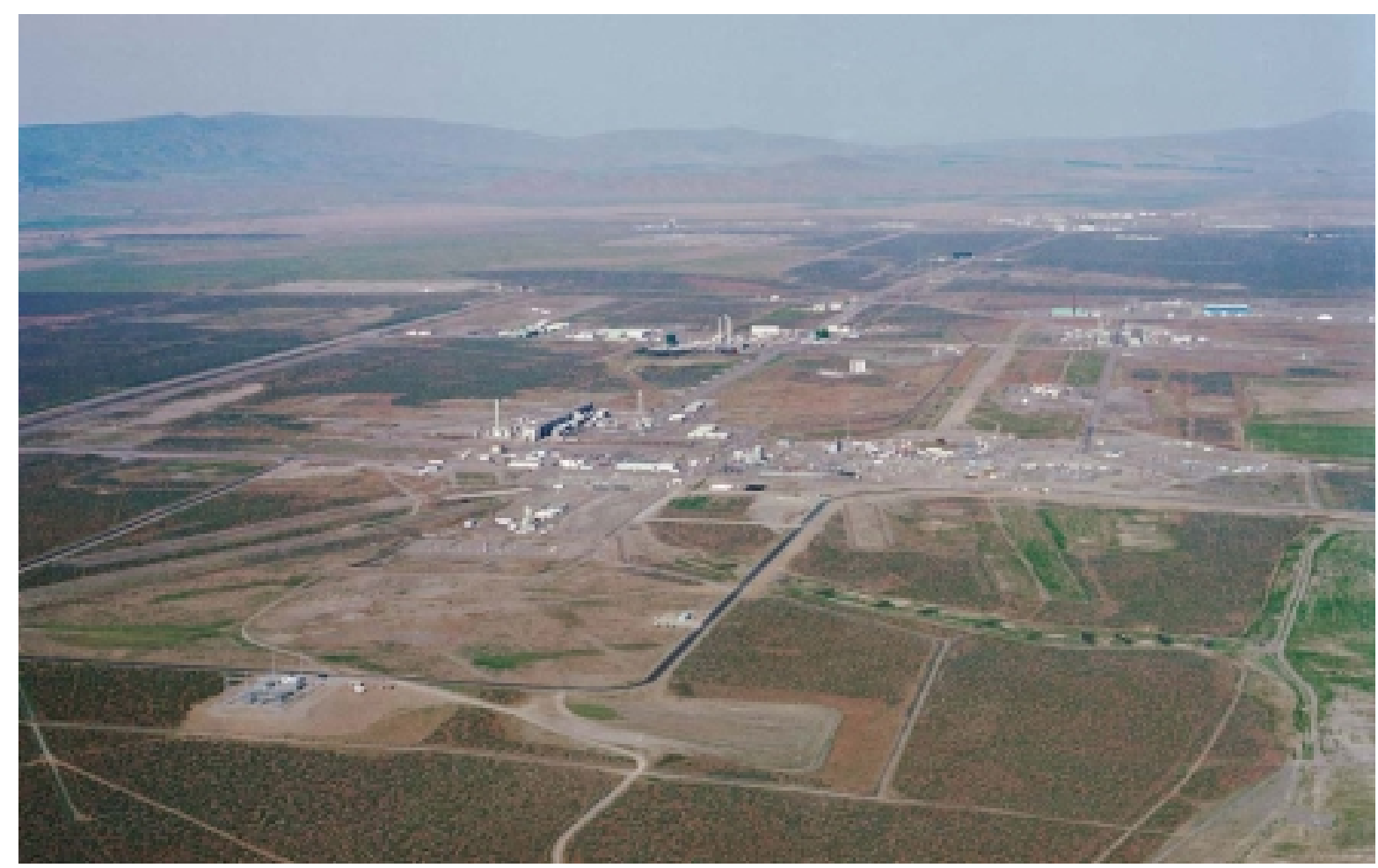

An aerial photo showing the location of the new waste vitrification plant location (in the foreground). The 200-West Area and B Plant are in the background.

A major focus of DOE's environmental management mission at Hanford is cleanup of the site's waste from more than 45 years of nuclear weapons production. Managing this legacy waste-as well as other waste from past and current operations - involves safe storage, treatment, and final disposal of a large amount and variety of radioactive and chemical materials. It also involves remediating several hundred inactive waste disposal sites and stabilizing inactive facilities and the material inside them to prevent leaks or avoidable radiation exposures. Environmental restoration and pollution prevention are key parts of the environmental management mission.

An agreement between DOE, the Washington State Department of Ecology, and the U.S. Environmental Protection Agency (EPA), known as the Tri-Party Agreement, provides the legal and procedural basis for cleanup of waste sites at Hanford. The Tri-Party Agreement contains a schedule, utilizing numerous enforceble major and interim milestones and unenforceble target dates, which reflects a concerted goal of achieving full regulatory compliance and remediation. 


\section{Waste Storage, Treatment, and Disposal}

Waste management at Hanford includes designing, building, and operating a variety of facilities to store, treat, and prepare the waste for disposal. At Hanford, a large part of this process involves safely managing 177 underground storage tanks (149 single-shell tanks and 28 double-shell tanks) that contain millions of liters of high-level liquid waste.

Cleanup activities on the Hanford Site generate radioactive, hazardous, and mixed waste. This waste is handled and prepared for safe storage on the site or shipped to offsite facilities for treatment and disposal. In 2000, cleanup activities generated 441,000 kilograms $(973,000$ pounds) of solid mixed waste and 700,000 kilograms (1.5 million pounds) of radioactive waste on the Hanford Site. There were also $\sim 1,380$ kilograms $(3,050$ pounds) of mixed waste and 6.9 million kilograms (15.3 million pounds) of radioactive waste received at Hanford from offsite.

In addition to newly generated waste, significant quantities of legacy waste remain from years of nuclear material production and waste management activities. Most legacy waste from past operations at the Hanford Site resides in waste sites that comply with the Resource Conservation and Recovery Act (RCRA) or is stored awaiting cleanup and ultimate safe storage or disposal. Examples includehigh-level radioactive waste stored in single- and double-shell tanks and transuranic waste stored in vaults and on storage pads.

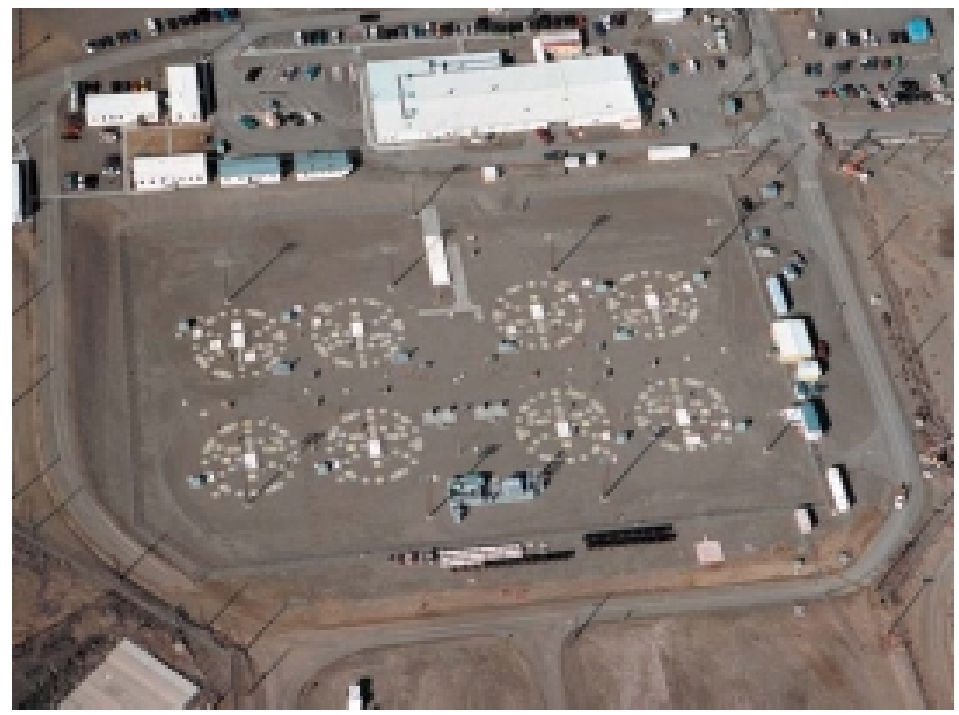

This photo shows an aerial view of a tank farm in the 200 Areas. Eighteen tank farms contain from 2 to 16 tanks each.

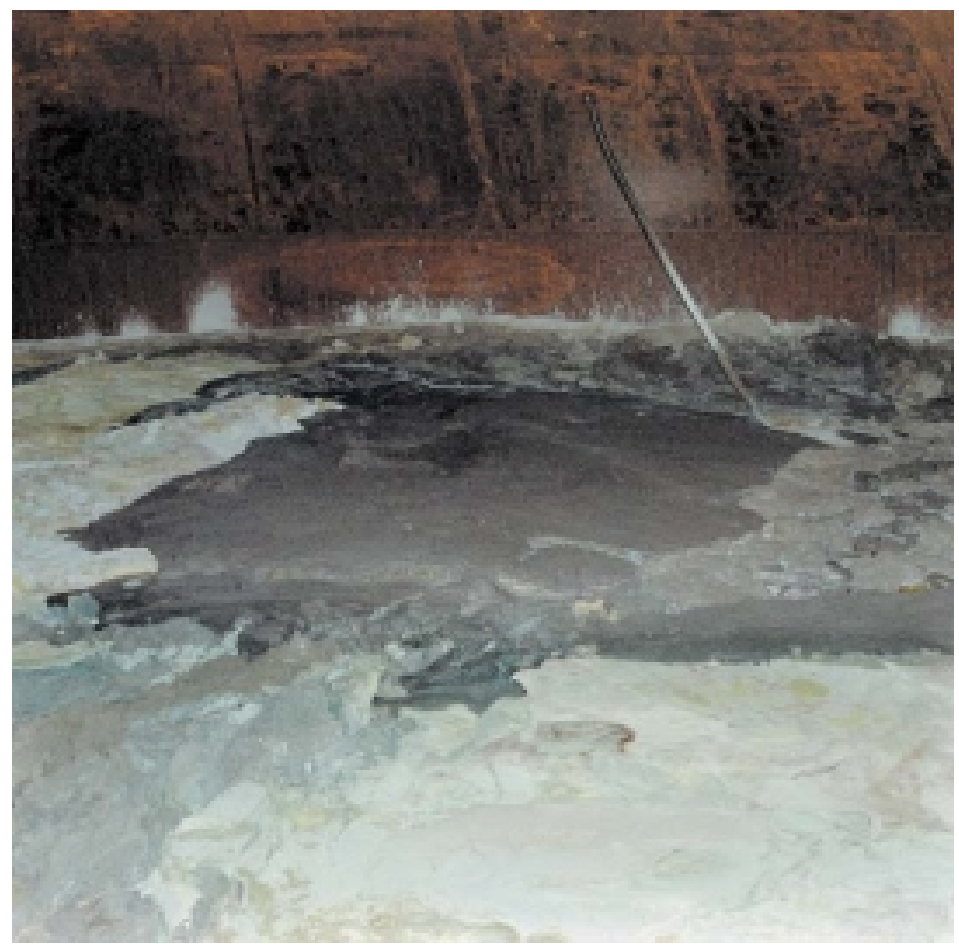

Waste stored in underground tanks at Hanford can be solid, liquid, or sludge like. This photo shows the surface of waste stored in a double-shell tank. 


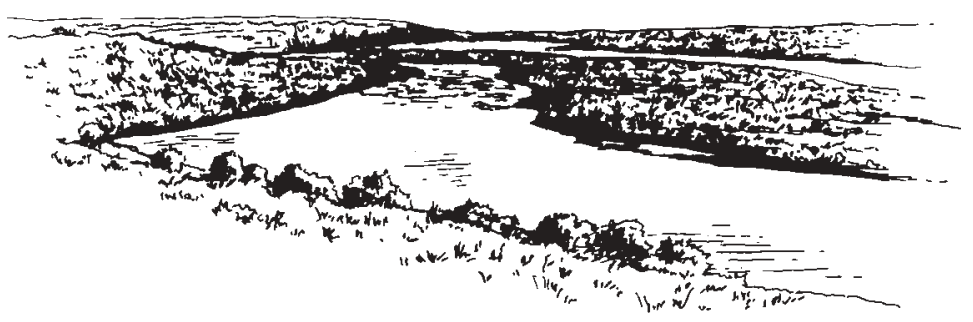

Waste Tanks

Underground waste storage tanks were built in groups (called tank farms) in the 200-East and 200-West Areas. The farms contain underground pipes so waste can be pumped between tanks, between farms, and between the 200-East and 200-West Areas.

Sixty percent of the nation's nuclear waste is stored in tanks at the Hanford Site. The DOE's goal is to safely remove the liquid waste from the tanks, separate the radioactive elements from non-radioactive chemicals, and create a solid form of waste that can be disposed. The approach selected to solidify the waste is called vitrification, a process that turns the liquid into a rock-like glass.

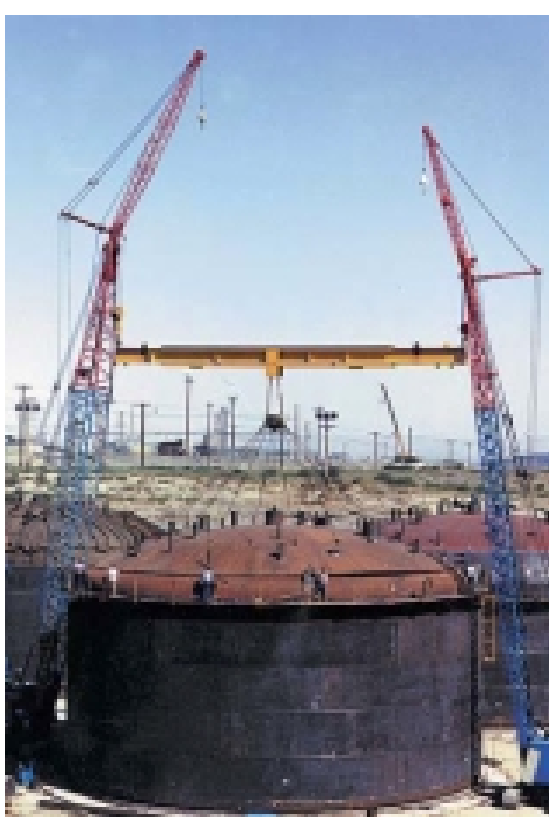

The Hanford Site contains underground storage tanks that contain 204 million liters (54 million gallons) of hazardous and radioactive wastes-enough to fill nearly 2,800 railroad tanker cars.
1973: largest estimated leak reported (tank 241-T$106 ; 435,000$ liters $[115,000$ gallons])

1988: tanks 241-AX-102, -C-201, -C-202, -C-204, and -SX-104 confirmed as having leaked

1992: latest tank (241-T101) added to list of tanks assumed to have leaked, bringing total to 67 singleshell tanks

1994: tank 241-T-111 was declared to have leaked again

- number of flammable gas tanks (of concern because of the possibility of the generation, retention, and potential release of flammable gases by the tank waste)

- 19 single-shell tanks

- 5 double-shell tanks
Since the 1950s, waste leaks from 67 single-shell tanks have been detected, and some of this waste has reached groundwater underlying the 200 Areas. To date, scientists estimate that 2.8 to 3.9 million liters (750,000 to 1 million gallons) of radioactive waste have leaked from single-shell tanks. All single-shell tanks have exceeded their design life by about 30 years.

In 1998, Congress established the DOE Office of River Protection to manage storage, treatment, and disposal of the high-level liquid waste stored in the underground tanks. The status of the waste tanks as of December 2000 is as follows:

- number of tanks assumed to have leaked

- 67 single-shell tanks

- 0 double-shell tanks

- chronology of single-shell tank leaks

1956: first tank reported as suspected of leaking (tank 241-U-104)
- number of organic tanks (of concern because of the potential for uncontrolled reactions of organic solvents present in some tanks) and high-heat tanks

- 0 single-shell tanks

- 0 double-shell tanks.

So far, 125 of 149 (84\%) single-shell tanks have been stabilized; the tank stabilization program is scheduled to be completed in 2004. At the end of 2000, 108 single-shell tanks had intrusion prevention devices installed, and 40 single-shell tanks were disconnected from the piping system and capped to avoid inadvertent liquid additions to the tanks.

During 2000, four tanks were declared stable. Liquid waste from 14 single-shell tanks was pumped into the double-shell tanks, removing 2.3 million liters (600,000 gallons) of waste from the single-shell tanks. A pipeline safely transferred waste from the 200-West to the 200-East Area. 
Immobilization

\section{of Waste \\ Contained in \\ Underground \\ Tanks}

Approximately 204 million liters (54 million gallons) of radioactive and hazardous waste are stored in 149 underground singleshell tanks and 28 underground double-shell tanks. The DOERiver Protection Program is currently upgrading facilities to deliver waste from underground storage tanks to a planned treatment facility.

Treatment will separate the waste into a low-radioactivity fraction and a high-radioactivity and transuranic fraction. Both fractions will be vitrified in a process that will destroy or extract organic constituents, neutralize or deactivate dangerous waste, and immobilize toxic metals.

The immobilized low-radioactivity portion will be disposed of in a facility on the Hanford Site. The immobilized high-radioactivity fraction will be stored onsite until a geologic repository is available offsite for permanent disposal. Tri-Party Agreement milestones specify December 2028 for completion of pretreatment and immobilization of the tank wastes.

In December 2000, the Office of River Protection awarded a contract to Bechtel-Washington to design, build, and commission the vitrification plant.

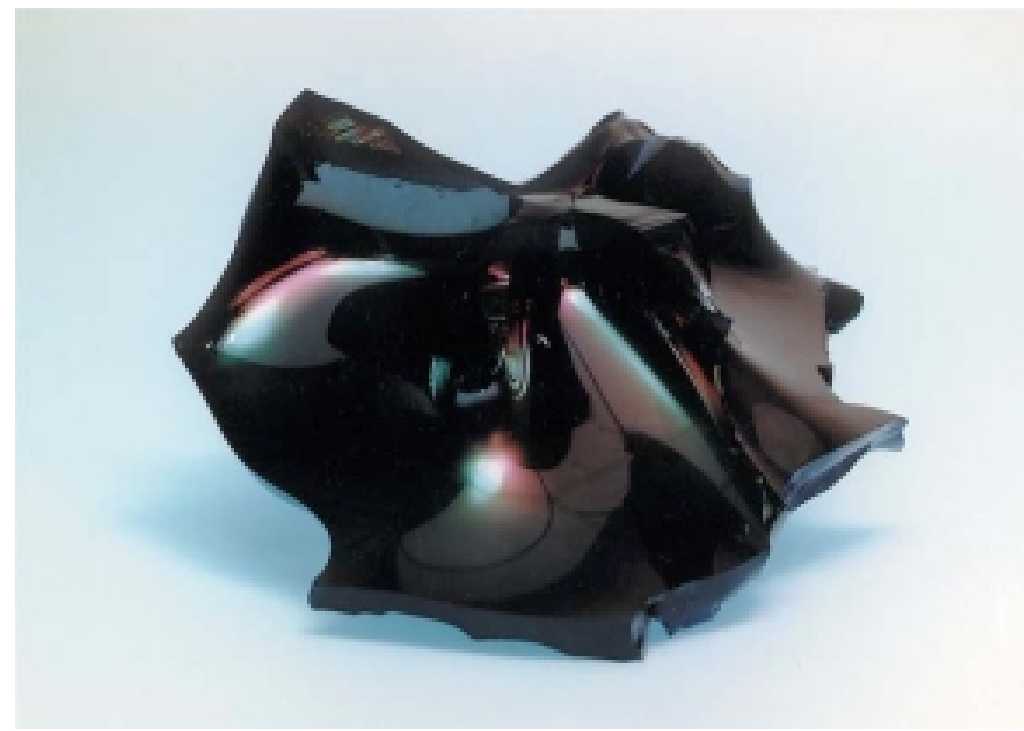

Vitrification turns waste into glass that looks like this-hard, shiny, and rock like. The glass traps radioactive and hazardous waste and keeps them from escaping into the environment.

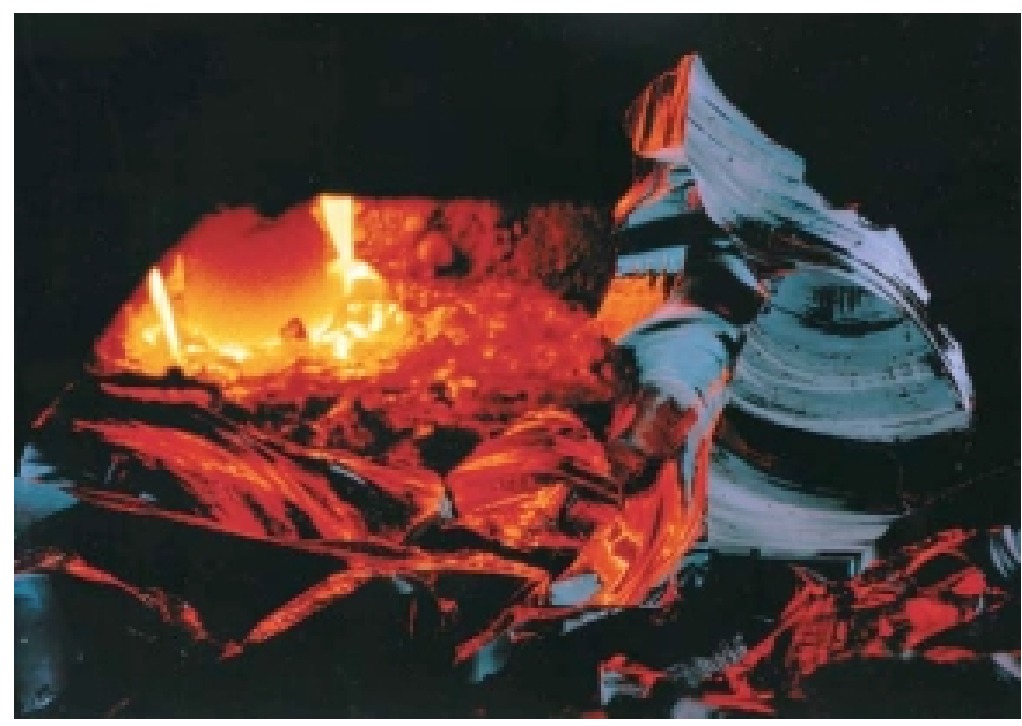

DOE has chosen vitrification to stabilize and contain spilled and leaking radioactive and hazardous chemical waste. Vitrification uses electric power to melt soil and rock; the mass cools into glasslike blocks that will hold materials safely.

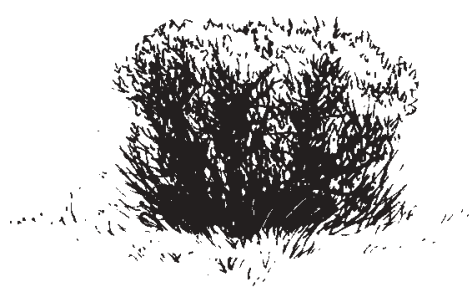




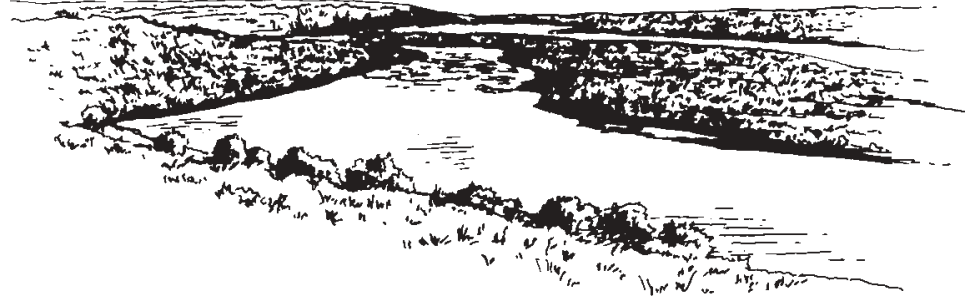

Liquid Waste Management

Liquid waste, called effluent, is managed in storage, treatment, and disposal facilities in compliance with RCRA and state regulations, as briefly described below.

\section{2-A Evaporator}

The 242-A Evaporator processes double-shell tank waste into a concentrate (that is returned to the tanks) and a process condensate stream. In 2000, the evaporator treated 5.07 million liters $(1.34$ million gallons) of tank waste and produced 3.09 million liters $(815,000$ gallons) of process condensate that were sent to the Liquid Effluent Retention Facility.

\section{Liquid Effluent Retention Facility}

This facility consists of three surface basins that store liquid waste, including condensate from the 242-A Evaporator. Approximately 42.3 million liters (11.2 million gallons) of liquid waste were stored in the facility's basins at the end of 2000 .

\section{Areas Treated Effluent Disposal Facility}

This facility collects and disposes of non-RCRApermitted waste that has been treated using "best available technology/all known and reasonable treatment." Approximately 502 million liters ( 133 million gallons) of effluent were discharged to two 2-hectare (5-acre) disposal ponds located east of the 200-East Area. The facility discharge permit requires monitoring of the effluent and the groundwater to ensure concentrations for some constituents are not exceeded.

\section{Area Treated Effluent Disposal Facility}

Industrial wastewater generated throughout the Hanford Site is accepted and treated in the 300 Area Treated Effluent Disposal Facility. Laboratories, research facilities, office buildings, and former fuel fabrication facilities in the 300 Area constitute the primary sources of wastewater. Wastewater consists of cooling water, stream condensate, and other industrial wastewaters. The facility treated $\sim 231$ million liters (61 million gallons) of wastewater in 2000.

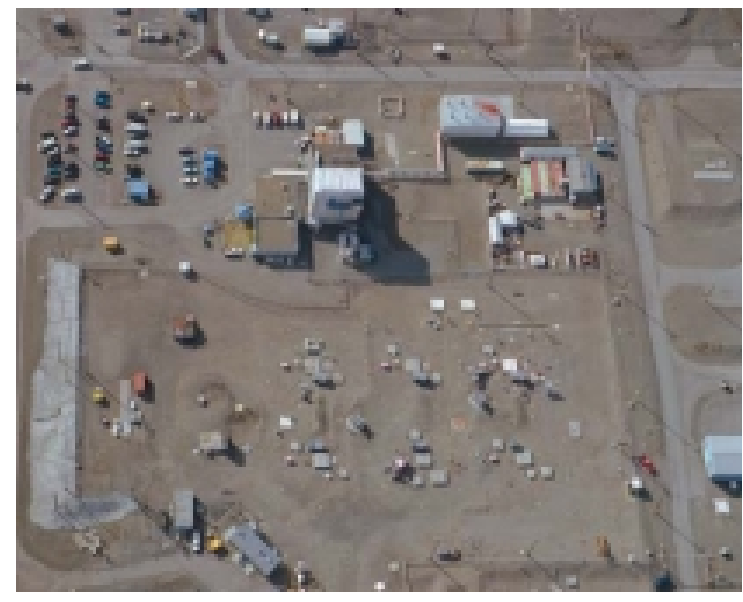

The 242-A Evaporator concentrates dilute liquid tank waste by evaporation.

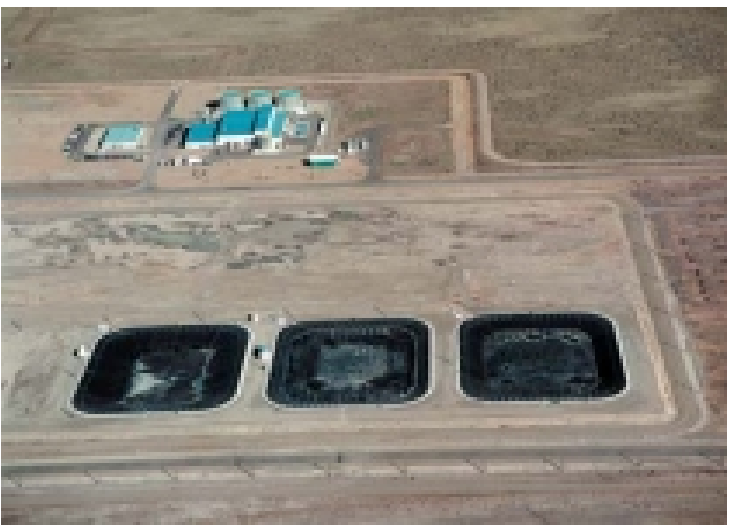

The three basins shown in this photo of the Liquid Effluent Retention Facility are constructed of two, flexible, high-density polyethylene membrane liners.

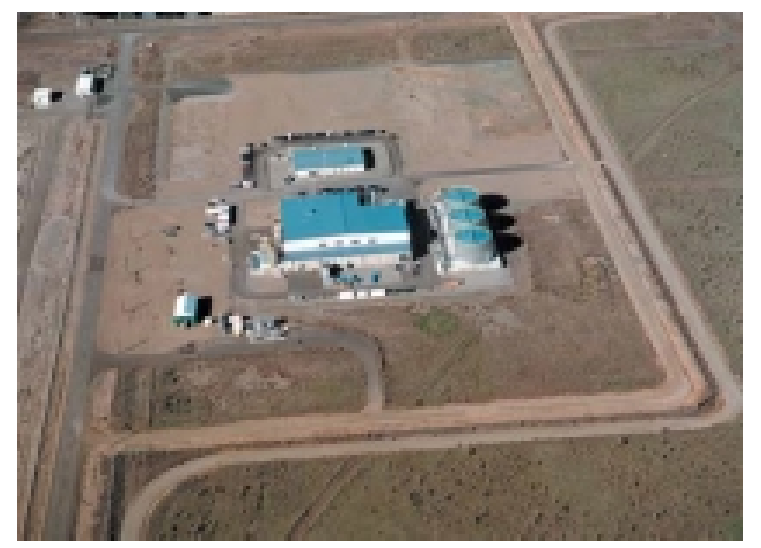

The 200 Areas Treated Effluent Disposal Facility treats and stores radioactive waste. 


\section{Solid Waste Management}

Storage, treatment, and disposal of solid waste takes place at a number of locations on the Hanford Site, such as those described in the following paragraphs. Solid waste may originate from work on the Hanford Site or from sources offsite that are authorized by DOE to ship waste to the site.

\section{Central Waste Complex}

Ongoing cleanup and research and development activities, as well as remediation activities, generate the waste received at the Central Waste Complex from onsite sources. Offsite waste comes primarily from DOE research facilities, other DOE sites, and Department of Defense facilities. The waste includes lowlevel, transuranic, mixed waste, and radioactively contaminated polychlorinated biphenyls.

\section{Waste Receiving and Processing Facility}

The Waste Receiving and Processing Facility analyzes, characterizes, and prepares drums and boxes of waste for disposal. Waste destined for the facility includes Hanford's legacy waste as well as materials generated from current and future site cleanup activities. The waste consists primarily of clothing, gloves, face masks, and small tools.

\section{Navy Reactor Compartments}

Eight disposal packages containing defueled U.S. Navy reactor compartments were received and placed in Trench 94 in the 200-East Area during 2000. All eight reactor compartments were from submarines. This brings the total number of reactor compartments received to 94 . All reactor compartments shipped to the Hanford Site for disposal have originated from decommissioned nuclearpowered submarines or cruisers.

Washington State Department of Ecology regulates the disposal of reactor compartments as dangerous waste because lead is used as shielding. The reactor compartments also are managed as mixed waste because of their radioactivity.

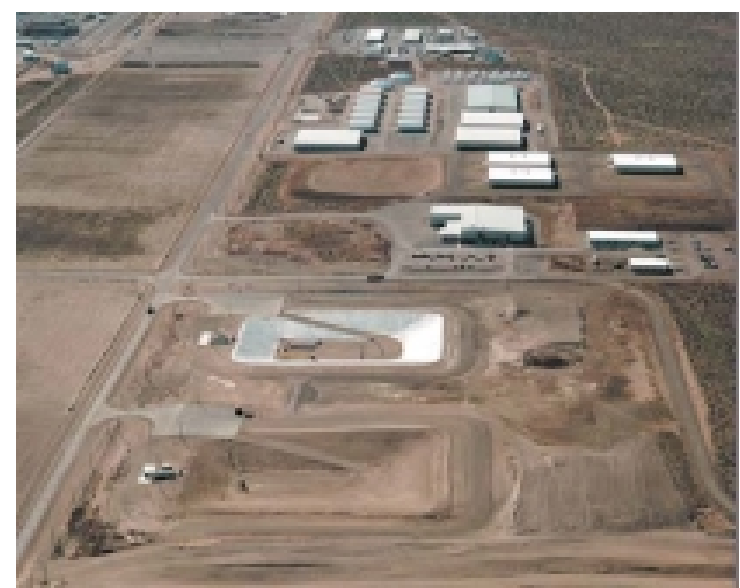

The Central Waste Complex receives waste from Hanford Site cleanup activities and from other DOE and Defense Department facilities.

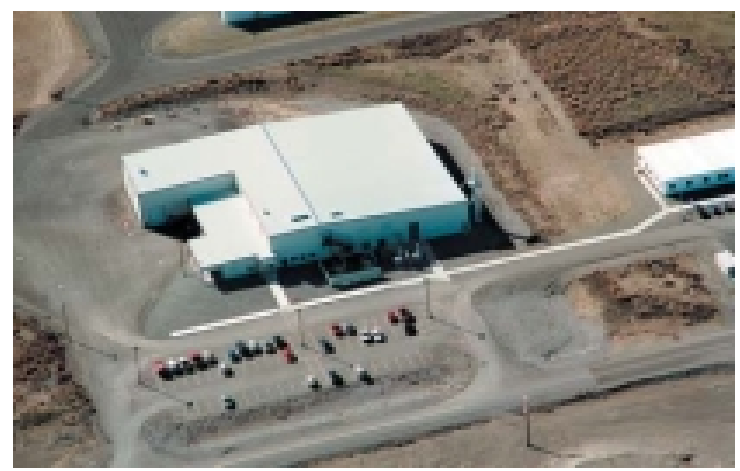

Clothing, masks, and small tools suspected of being contaminated with plutonium are sent to the Waste Receiving and Processing Facility.

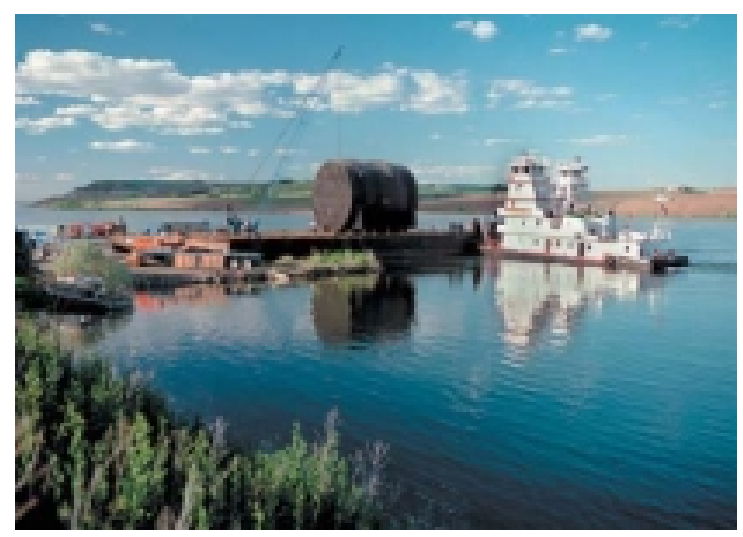

Defueled reactor components from nuclear-powered submarines and cruisers are barged to the Hanford Site and buried in a trench in the 200-East Area. 


\section{Environmental Restoration}

Environmental restoration at Hanford involves stabilizing contaminated soil; remediating disposal sites; decontaminating, decommissioning, and demolishing former plutonium production process buildings, nuclear reactors, and separation plants; and mitigating effects to biological and cultural resources from site development and environmental cleanup and restoration activities.

\section{Environmental Restoration Disposal Facility}

This disposal facility is located near the 200 West Area and began operations in July 1996. Constructed with double liners and a leachate collection system, the facility was designed to serve as the central disposal site for contaminated waste removed during cleanup operations conducted under the Comprehensive Environmental Response, Compensation, and $\mathrm{Li}$ ability Act (CERCLA) on the Hanford Site.

Cleanup materials may include soil, rubble, or other solid waste materials contaminated with hazardous, low-level radioactive, or mixed (combined hazardous chemical and radioactive) waste. In 2000, the facility received the first waste into the new cells that were constructed in 1999. Later in 2000, an interim cover was placed over portions of cells that had been filled to their final configuration. As of early

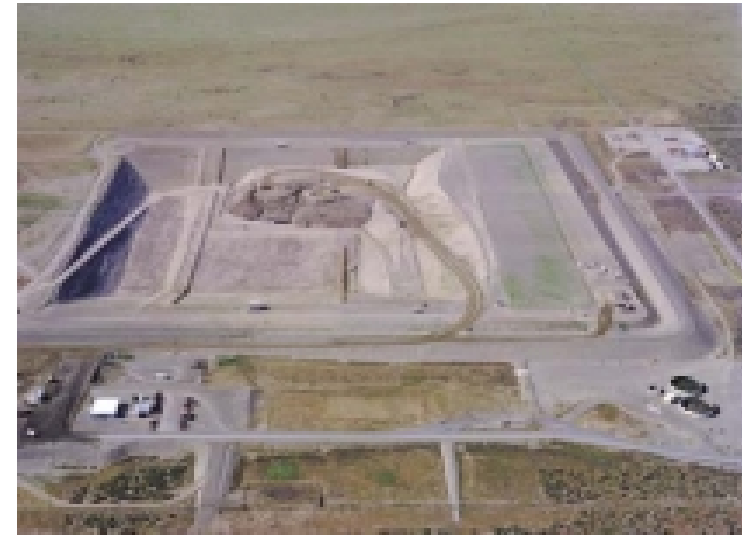

The Environmental Restoration Disposal Facility is located south of the 200-West Area on the Hanford Site.

2001, the facility had received 2.4 million metric tons (2.65 million tons) of waste.

\section{Waste Site Remediation}

Remediation continued through 2000 at several liquid waste disposal sites in the 100-B/C, 100-D, and 100-H Areas. In July 2000, work began at the 100-F and 100-N remediation sites. Over 1.8 million metric tons (over 2 million tons) of contaminated soil have been removed from the remediation sites. This soil has been transported to the Environmental Restoration Disposal Facility since the beginning of waste site remediation operations in 1996.

$\begin{array}{ll} & \text { Status of Waste Site Remediation } \\ \text { Location of Waste Site } & \text { Amount of Contaminated Soils Removed, metric tons (tons) } \\ 100-B / C \text { Area } & 12 \text { waste sites backfilled in } 2000 ; 621,100(685,000) \text { since startup in } 1996 \\ \text { 100-D/DR Area } & 67,000(74,000) \text { from } 10 \text { waste sites in } 2000 ; 641,000(709,000) \text { since } \\ & \text { startup in } 1996 \\ & 190,600(211,000) \text { from nine waste sites in } 2000 ; 412,000(455,000) \text { since } \\ \text { 100-H Area } & \text { startup in } 1996 \\ & 148,300(164,000) \text { from four waste sites since startup in } 2000 \\ \text { 100-F Area } & 25,000(28,000) \text { since startup in } 2000 \\ 100-\text { N Area } & 94,700(104,600) \text { in } 2000 ; 408,700(531,200) \text { since startup in } 1997 \\ 300 \text { Area } & \end{array}$




\section{Decommissioning Project}

Decontamination and decommissioning continued in 2000 in the 100-D and 100-F Areas. During the year, all planned demolition was completed at the DR and F Reactors. Ancillary facilities that supported the DR and F Reactors were removed and disposed. The activities support the interim safe storage of the reactor buildings. Other decontamination and decommissioning work started during the year at the $\mathrm{D}$ and $\mathrm{H}$ Reactor buildings.

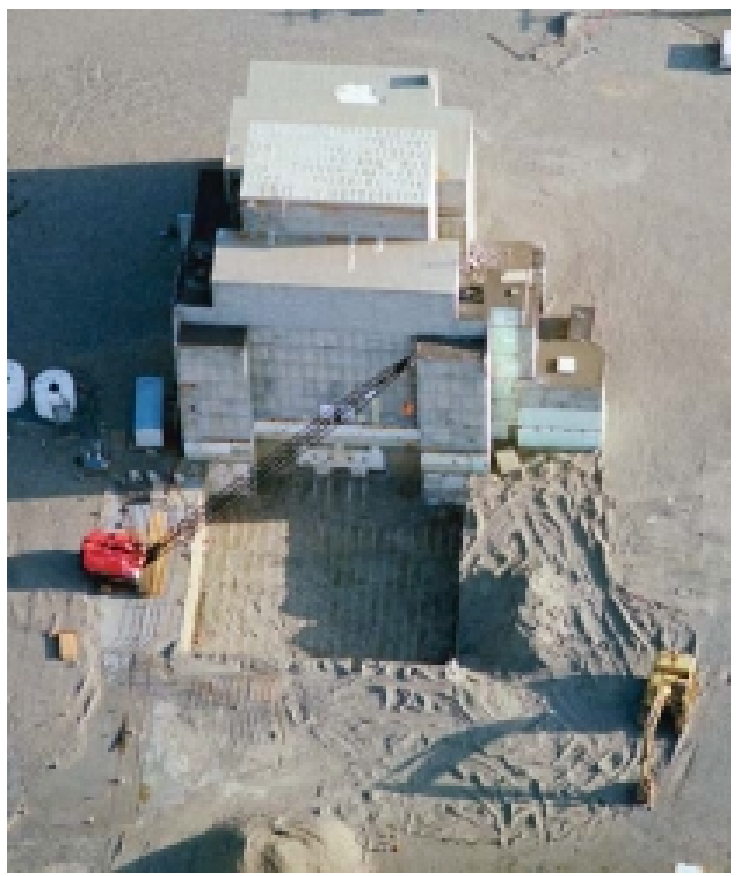

The old fuel storage basin next to F Reactor was removed during 2000.

\section{Revegetation and Mitigation Planning}

Valuable wetland habitat was created near the Columbia River in the process of excavating fill material from Borrow Pit 24. This process combined a restoration project with a construction project to create a valuable wildlife habitat. Wetland species including cattails and willows have begun to inhabit the area.

Some native sagebrush plants in Horn Rapids Park (off of State Highway 240) burned during the June 2000 wildfire were replaced. Approximately 8,100 sagebrush plants were planted by volunteers along transects within the park and adjacent to the Yakima River. The planted sagebrush will help replace habitat and provide a seed source to the area.

The final phase of revegetation on several former 100-B/C Area liquid effluent disposal sites was completed. The 5.3-hectare (13-acre) area was planted with 2,600 sagebrush plants following the hydroseeding of native grasses and forbs in December 1999. The planted sites will be monitored for 5 years to ensure the planting effort is successful.

In concert with the U.S. Fish and Wildlife Service, $\sim 80,000$ bareroot and potted sagebrush plants were planted on about 80 hectares (200 acres) at 9 locations on the Fitzner/Eberhardt Arid Lands Ecology Reserve Unit during December 2000.

\section{Pollution Prevention Program}

Pollution prevention is DOE's preferred approach to environmental management. The Hanford Site Pollution Prevention Program is an organized and continuing effort to reduce the quantity and toxicity of hazardous, radioactive, mixed, and sanitary wastes.

In 2000, pollution prevention efforts on the Hanford Site helped reduce the amount of material disposed by using source reduction and by recycling an estimated 155,000 cubic meters (202,000 cubic yards) of radioactive mixed waste, 26,000 metric tons (28,700 tons) of RCRA hazardous/dangerous waste, 860,000 liters $(227,000$ gallons $)$ of process wastewater, and 1,800 metric tons (1,984 tons) of sanitary waste. Estimated savings in waste disposal costs in 2000 exceeded $\$ 46$ million. In addition, during 2000 the Hanford Site recycled 430 metric tons (470 tons) of paper products and 510 metric tons (560 tons) of various metals. 


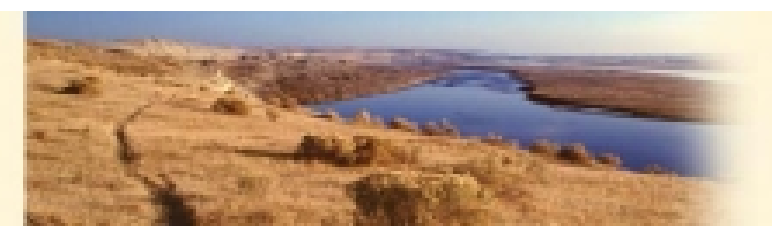

\section{Compliance with Environmental Regulations}

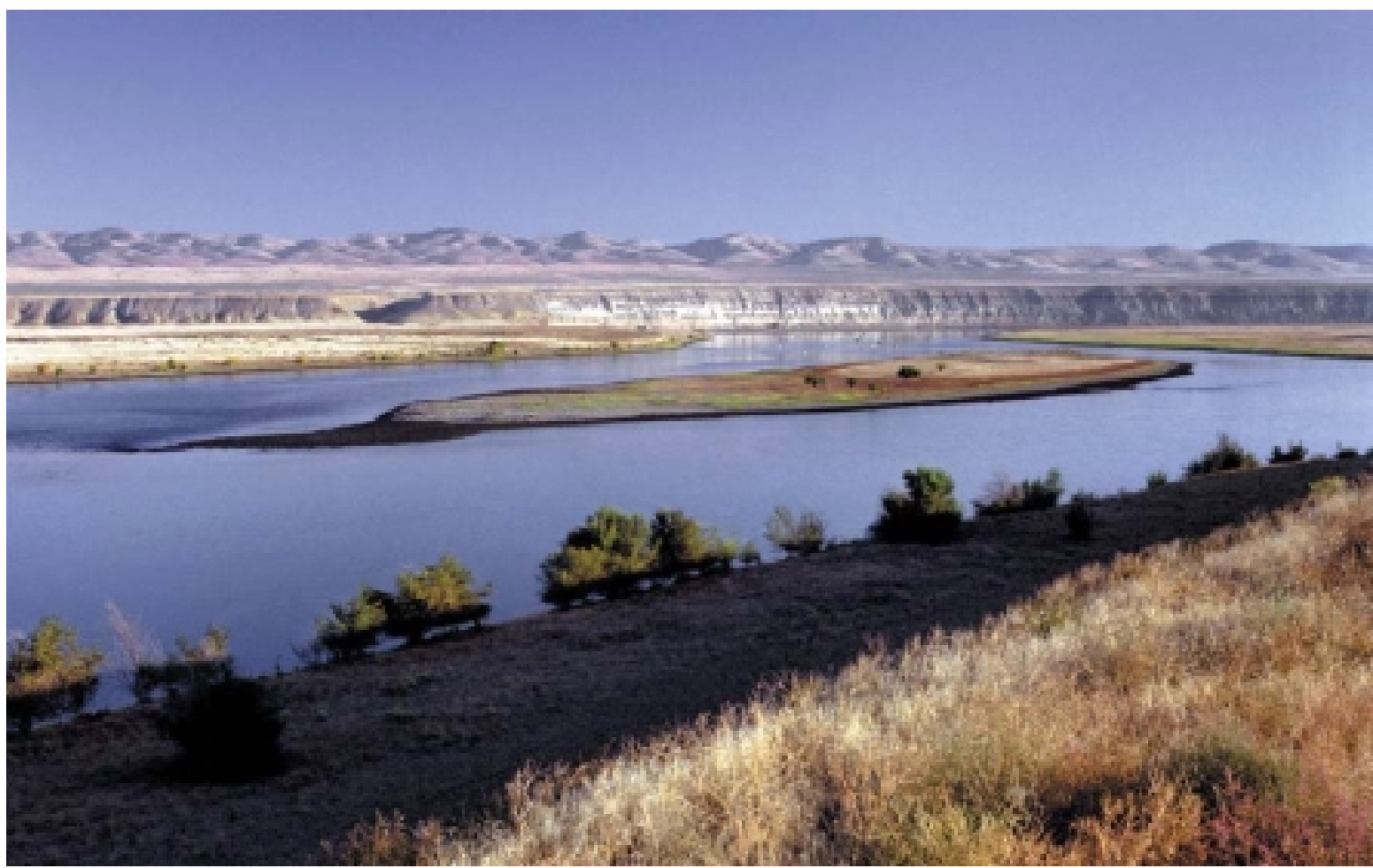

The Columbia River bordering the Hanford Site was closed to public access from 1943 until the late 1970s between Priest Rapids Dam and just north of Richland, Washington. In June 2000, a presidential proclamation established the Hanford Reach National Monument. Because the Reach is undammed and undredged, it is the last free-flowing section of the mainstem Columbia River in the United States and the last significant spawning location for Columbia River fall chinook salmon.

Environmental standards and regulations applicable at DOE facilities fall into three categories: 1) DOE directives; 2) federal legislation and executive orders; and 3) state and local statutes, regulations, and requirements. Several federal, state, and local government agencies monitor and enforce compliance with applicable environmental regulations at the Hanford Site. Major agencies include EPA, Washington State Department of Ecology, Washington State Department of Health, and Benton Clean Air Authority. These agencies issue permits, review compliance reports, participate in joint monitoring programs, inspect facilities and operations, and/or oversee compliance with applicable regulations. DOE, through compliance audits and its directives to its field offices, initiates and assesses actions for compliance with environmental requirements.

Activities at the Hanford Site in 2000 were conducted in compliance with DOE directives, federal environmental protection statutes, and related state and local environmental protection regulations.

The table on the following page summarizes DOE's compliance with federal acts in 2000. Performance related to the Hanford Federal Facility Agreement and Consent Order is described in the following subsection. 


\section{Compliance with Federal Acts at the Hanford Site in 2000}

\section{Regulation}

Comprehensive Environmental Response, Compensation, and Liability Act (CERCLA)

\author{
Emergency Planning and \\ Community Right-to-Know Act
}

Resource Conservation and Recovery Act (RCRA)

\section{What it Covers}

Sites already contaminated by hazardous materials

\section{Status}

Work on these sites was in compliance with CERCLA requirements and met the schedules established by the Tri-Party Agreement.

The public's right to information about hazardous chemicals in the community and establishes emergency planning procedures

Hazardous waste being generated, transported, stored, treated, or disposed. The act primarily covers ongoing waste management at active facilities.
The Hanford Site was in compliance with the reporting and notification requirements contained in this act.
The Washington State Department of Ecology identified several violations during 2000. The violations identified RCRA-regulated waste that was shipped offsite and violations of the management agreement. Another violation identified 26 drums of dangerous and/or mixed waste collected more than 20 years ago that were improperly labeled, and a drum of flocculent that was not properly designated as required by state regulation. Other violations included an inspection matter and the application of regulations to determine the integrity of the double-shell tank system. All problems identified have been, or are being, corrected.

According to the Washington State Department of Health, air emissions from Hanford Site facilities were well below state and federal standards. However, the calibration of some air monitoring equipment needed to be corrected, and in one instance, proper permits were not obtained.

Copper, manganese, and zinc were detected at levels higher than permit levels at one discharge line near the 300 Area shoreline. Also, some 300 Area procedures had to be revised, and equipment at the 100-N Sewage Lagoon had to be repaired. In addition, the permit limits for $\mathrm{pH}$ and total suspended solids were exceeded at the 100-N Sewage Lagoon, though the cause was believed to be an algae bloom caused by warm weather. 


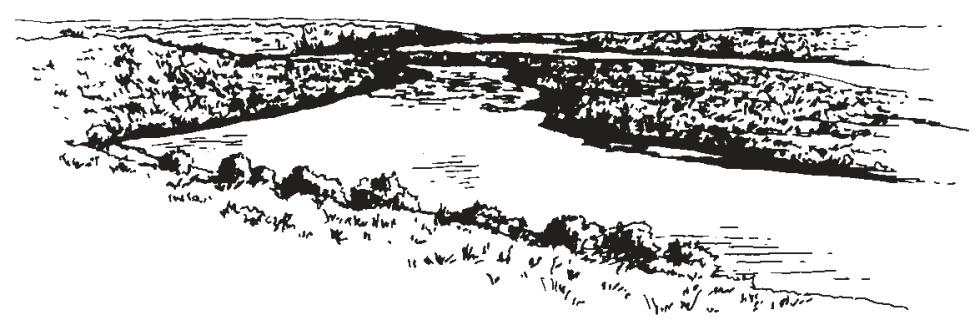

Regulation

\begin{tabular}{|c|c|c|}
\hline Safe Drinking Water Act & $\begin{array}{l}\text { Drinking water supplies operated } \\
\text { by DOE }\end{array}$ & $\begin{array}{l}\text { All Hanford drinking water systems } \\
\text { were in compliance with Washington } \\
\text { State Department of Health guide- } \\
\text { lines. There was one exception on } \\
\text { February } 3,2000 \text {, when sampling } \\
\text { results indicated the maximum con- } \\
\text { taminant level of coliform bacteria } \\
\text { was exceeded at the } 200 \text {-East Area, } \\
\text { but no E.coli were found. }\end{array}$ \\
\hline Toxic Substances Control Act & $\begin{array}{l}\text { Primarily chemicals called poly- } \\
\text { chlorinated biphenyls }\end{array}$ & $\begin{array}{l}\text { Hanford was in compliance with } \\
\text { the requirements of this act. }\end{array}$ \\
\hline $\begin{array}{l}\text { Federal Insecticide, Fungicide, } \\
\text { and Rodenticide Act }\end{array}$ & Storage and use of pesticides & $\begin{array}{l}\text { Hanford was in compliance with } \\
\text { the requirements of this act. }\end{array}$ \\
\hline Endangered Species Act & Rare species of plants and animals & $\begin{array}{l}\text { Hanford activities complied with the } \\
\text { requirements of this act. The } \\
\text { Hanford Site has eight plant } \\
\text { species, two fish species, and five } \\
\text { bird species on the federal or state } \\
\text { list of threatened or endangered } \\
\text { species. }\end{array}$ \\
\hline $\begin{array}{l}\text { American Indian Religious } \\
\text { Freedom Act, Antiquities Act, } \\
\text { Archaeological and Historic } \\
\text { Preservation Act, Archaeological } \\
\text { Resources Protection Act, Historic } \\
\text { Sites Buildings and Antiquities Act, } \\
\text { National Historic Preservation Act, } \\
\text { and Native American Graves } \\
\text { Protection and Repatriation Act }\end{array}$ & Cultural resources & $\begin{array}{l}\text { Hanford was in compliance with } \\
\text { the requirements of these acts. }\end{array}$ \\
\hline National Environmental Policy Act & $\begin{array}{l}\text { Environmental impact statements } \\
\text { for federal projects }\end{array}$ & $\begin{array}{l}\text { Hanford was in compliance with } \\
\text { the requirements of this act. }\end{array}$ \\
\hline Migratory Bird Treaty Act & $\begin{array}{l}\text { Migratory birds or their feathers, } \\
\text { eggs, or nests }\end{array}$ & $\begin{array}{l}\text { Hanford was in compliance with } \\
\text { the requirements of this act. There } \\
\text { are over } 100 \text { species of birds that } \\
\text { occur on the Hanford Site that are } \\
\text { protected by this act. }\end{array}$ \\
\hline
\end{tabular}

\section{Status}

All Hanford drinking water systems were in compliance with Washington Department of Health guideFebruary 3,200 was exceeded at the 200-East Area, Hanford was in compliance with

Hanford was in compliance with Hanford activities complied with the thents of this act. The species, two fish species, and five bird species on the federal or state ist of threatened or endangered

Hanford was in compliance with

\section{Hanford Federal Facility Agreement and Consent Order}

A key element in Hanford's compliance program is the Tri-Party Agreement. The Tri-Party Agreement is an agreement among the EPA, Washington State Department of Ecology, and DOE to achieve compliance with the remedial action provisions of the Comprehensive Environmental Response, Compensation, and Liability Act (CERCLA) and with treatment, storage, and disposal unit regulation and corrective action provisions of the Resource Conservation and Recovery Act (RCRA).
The Tri-Party Agreement 1) defines the RCRA and the CERCLA cleanup commitments, 2) establishes responsibilities, 3 ) provides a basis for budgeting, and 4) reflects a concerted goal to achieve regulatory compliance and remediation with enforceable milestones in an aggressive manner. Also, the Tri-Party Agreement contains requirements for how to involve the public with Hanford Site decisions. 
The Tri-Party Agreement has continued to evolve as site cleanup progresses. Significant changes to the agreement have been negotiated to meet the changing conditions and cleanup needs. All significant changes to the agreement undergo a process of public involvement that ensures communication and addresses the public's values prior to final approvals.
From 1989 through 2000, 689 milestones and 264 target dates were completed on or ahead of schedule. In 2000, 45 of 48 specific Tri-Party Agreement cleanup milestones were completed on or before their required due dates. Two milestones were delayed because of programmatic issues, and one remained at issue at the time of this report.

\section{Environmental Occurrences}

An environmental occurrence is any sudden or sustained deviation from a regulated or planned performance at a DOE operation that has environmental protection and compliance significance. Onsite and offsite environmental occurrences (spills, leaks) of radioactive and non-radioactive effluent materials during 2000 were reported to DOE and other federal and state agencies as required by law. Three environmentally related off-normal occurrences took place in 2000:

- Elevated tritium was measured in a groundwater monitoring well at the 618-11 burial ground.

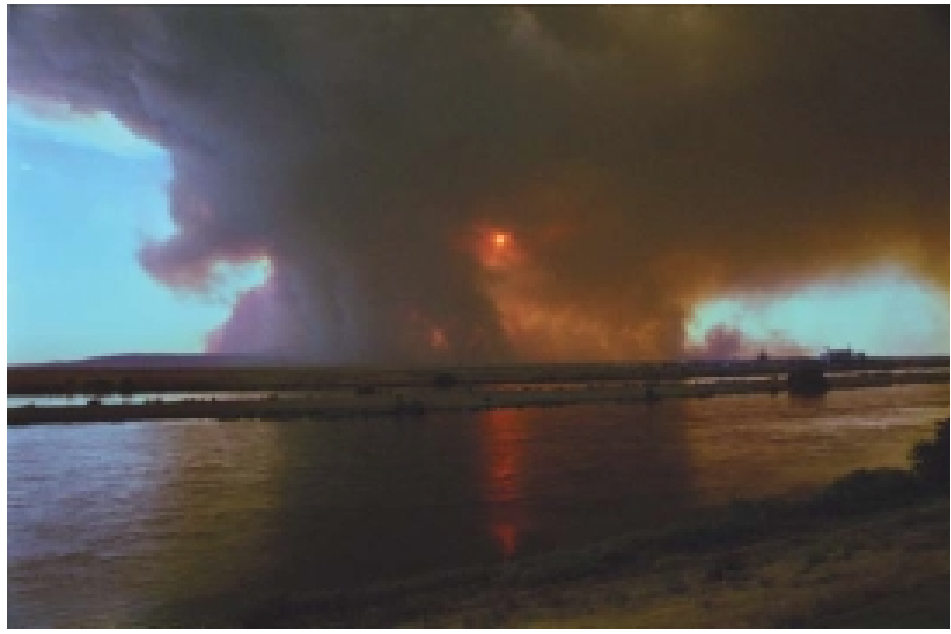

The magnitude of the Hanford wildfire can be seen in this photo near the 400 Area.
- Routine samples of drinking water exceeded the maximum contaminant levels for coliform bacteria in February 2000.

- Non-radioactive miscellaneous solid waste was inadvertently shipped to an offsite landfill in February 2000.

There was one emergency occurrence at the Hanford Site in 2000 — the 24 Command Wildfire. On June 27, 2000, dry vegetation was ignited by a vehicle accident near the western boundary of the Hanford Site on State Route 24, 2 miles west of the junction of State Routes 24 and 240. The resulting wildfire extensively burned federal, state, and private lands on and around the Hanford Site. The wildfire was declared out on July 1, 2000. Approximately 66,400 hectares $(164,000$ acres $)$ were burned including $~ 8,100$ hectares $(20,000$ acres $)$ of private land and 58,300 hectares (144,000 acres) of land managed by DOE and the U.S. Fish and Wildlife Service.
None of the Hanford Site's operational facilities burned, but the fire approached the boundaries of the 200-East and 200-West Areas.

The DOE has published a detailed report on the fire, which is available on the DOE website at www.hanford.gov/docs.rl-2000-63/index.htm. The Washington State Department of Health investigated potential radiological releases from the fire and reported their sample analysis results on their website at www.doh.wa.gov/ehp/rp/default.htm. The EPA, at the request of the Washington State Department of Health, collected high-volume air particulate samples in local communities from June 30 through July 3, 2000. The results of EPA sample analysis were reported on the Washington State Department of Health website at www.doh.wa.gov/ ehp/rp/epa_data.htm. 


\section{Potential Radiological Doses from 2000 Hanford Operations}

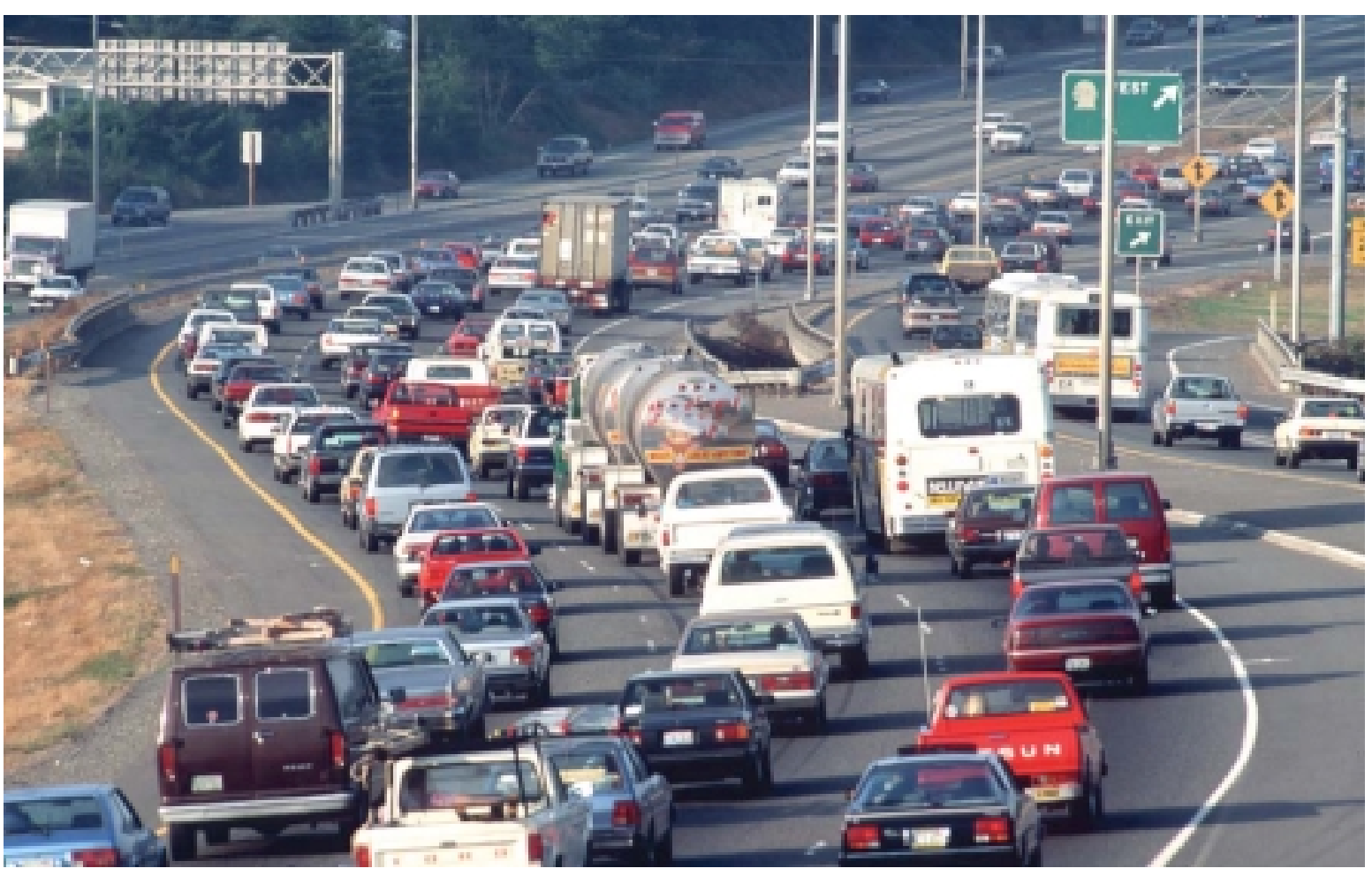

Driving or riding in a car 0.96 kilometer ( 0.6 mile) carries the same risk as the 2000 radiation dose to a maximally exposed individual. This individual would receive the same dose by flying about 2.5 kilometers ( 1.5 miles) on a commercial airliner, eating one 0.16-kilogram (5.75-ounce) charcoal-broiled steak, drinking 0.97 liter (about 1 quart) of chlorinated tap water, or smoking less than 1/100 of a cigarette.

In 2000, scientists evaluated potential radiological doses to the public resulting from exposure to Hanford Site liquid effluents and airborne emissions to determine compliance with pertinent regulations and limits.

The potential dose to the maximally exposed individual in 2000 from site operations was 0.014 millirem (0.00014 millisievert). Special exposure scenarios not included in this dose estimate include the hunting of game animals residing on the Hanford Site, and exposure to radiation at a publicly accessible location near the site boundary with the maximum exposure rate. Doses from these scenarios were small compared to the annual DOE dose limit.

The national average dose from background sources, according to the National Council on Radiation Protection, is 300 millirem per year (3 millisievert per year); the current DOE radiological dose limit for a member of the public is 100 millirem per year (1 millisievert per year). Therefore, the maximally exposed individual potentially received $0.014 \%$ of the DOE limit and $0.005 \%$ of the national average background dose. 


\section{Summary of Potential Radiological Doses from 2000 Hanford Operations}

\section{Radiological Dose Assessments}

Average radiological dose from natural sources and consumer products

DOE's annual radiological dose limit for a member of the public

Maximally exposed individual

Average individual dose

Maximum Hanford Site boundary dose

Dose to people consuming drinking water at the Fast Flux Test Facility

Maximum dose to non-DOE workers on the site (per Clean Air Act regulations)

Individual dose from non-DOE sources

\section{Dose Parameters}

The dose limit includes sources such as cosmic, terrestrial, internal, medical x-ray, radon, consumer products.

The dose limit includes air, drinking water, food, recreation and external radiation exposure pathways.

Hypothetical person's diet, dwelling place, and other factors were chosen to maximize the combined doses from all reasonable environmental pathways of exposure to radionuclides in Hanford Site effluents and emissions. In 2000, this individual was located at Riverview, directly across the Columbia River from Richland.

The average individual dose is based on a population of 380,000 within 80 kilometers (50 miles) of the onsite operating areas.

Boundary dose rates are not used to calculate annual doses to the general public because no one can actually reside at the boundary locations. The highest boundary location exposure rate in 2000 was measured along the 100-N Area shoreline of the Columbia River.

The potential dose to Fast Flux Test Facility workers assumes a consumption of 1 liter of drinking water from onsite wells per day (0.26 gallon per day) for 240 days.

Doses to members of the public employed at non-DOE facilities that were outside access-controlled areas on the Hanford Site.

Various non-DOE industrial sources of public radiation exposure exist at or near the Hanford Site.

\section{Dose}

300 millirem per year

100 millirem per year

0.014 millirem per year

0.0008 millirem per year

0.015 millirem per hour

0.02 millirem per year

0.046 millirem per year

$\sim 0.05$ millirem per year 


\section{Environmental Monitoring}

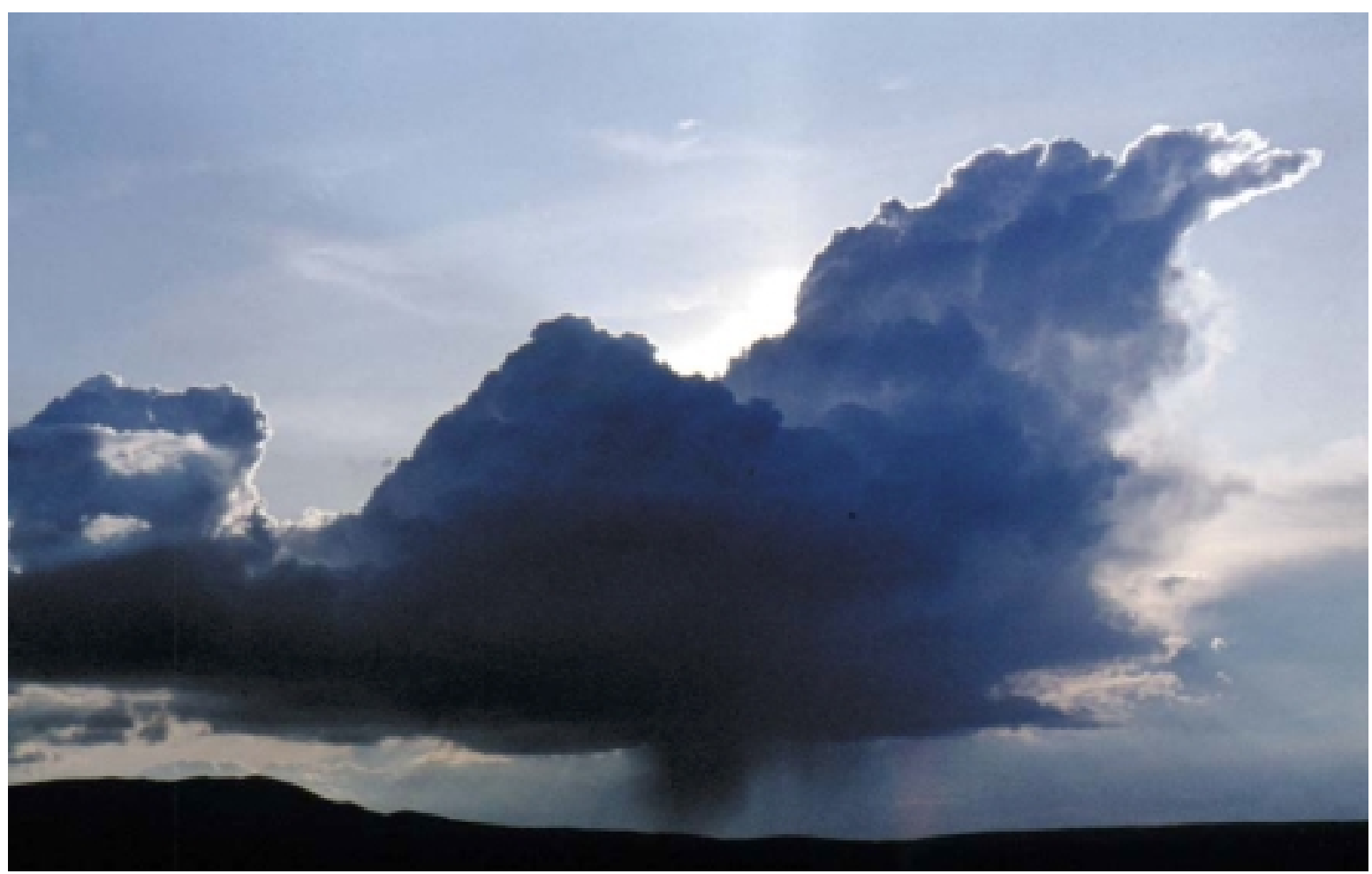

Environmental monitoring at the Hanford Site consists of collecting and analyzing samples of air, surface water, groundwater, drinking water, soil, natural vegetation, agricultural products, fish, and wildlife. In addition, external radiation levels in the environment are monitored, and radiological surveys are conducted to monitor and detect contamination. Air emissions and liquid discharges that may contain radioactive or hazardous materials also are monitored at and near site facilities.

The purpose of DOE's environmental monitoring programs is to measure chemical and radiological contaminants in the environment on and around the Hanford Site and assess the effects of these contaminants, if any, on the environment and the public. Information obtained from these efforts is provided to federal, state, county, and city agencies; regional Indian tribes; the general public; and other stakeholders. The collected data are used to document Hanford Site compliance with applicable federal, state, and local regulations; confirm adherence to DOE environmental protection policies; and support environmental management decisions.

Radiological and chemical constituents in groundwater at the Hanford Site also are monitored to characterize physical and chemical trends in the groundwater flow system, establish groundwater quality baselines, assess groundwater remediation, and identify new or existing groundwater problems. 
Effluent Monitoring

\section{Liquid Effluents}

Liquid effluents are discharged from facilities in all areas of the Hanford Site. Effluents that normally or potentially contain radionuclides include cooling water, steam condensates, process condensates, and wastewater from laboratories and chemical sewers. These wastewater streams are sampled and analyzed for gross alpha and beta levels as well as for selected radionuclides. In 2000, tritium in liquid effluents from 200 Areas facilities was the only radionuclide discharged to the ground at a state-permitted disposal site at Hanford. Liquid waste containing both radioactive and hazardous contaminants are stored at the 200 Area in underground waste storage tanks or monitored interim storage facilities.

\section{Air Emissions}

Atmospheric releases of radioactive material from the Hanford Site to the surrounding region are a potential source of human exposure. Most of the radionuclides in effluents at the site are nearing levels indistinguishable from the low concentrations in the environment that occur naturally or originated from atmospheric nuclearweapons testing. The environmental cleanup mission is largely responsible for the downward trend in radioactive emissions at Hanford.

The continuous monitoring of radioactive emissions involves analyzing samples collected at points of discharge to the environment, usually from a stack or vent. In the 100 Areas, radioactive airborne emissions originated from four points: the evaporation at the water filled $100-\mathrm{K}$ East and 100-K West Fuel Storage Basins, which contain irradiated fuel, the newly constructed Cold Vacuum Drying Facility, and from an analytical laboratory.

In the 200 Areas, 50 radioactive emission points were active in 2000. Primary sources of radionuclide emissions were the inactive Plutonium-Uranium Extraction Plant, Plutonium Finishing Plant, T Plant, 222-S Laboratory, underground waste storage tanks, and waste evaporators.

In 2000, 22 radioactive emission discharge points were active in the 300 Area. Primary sources of radioactive emissions were the 324 Waste Technology Engineering Laboratory, 325 Applied Chemistry Laboratory, 327 Post-Irradiation Laboratory, and 340 Vault and Tanks. Radioactive emissions were from research and development work and waste handling operations.

The 400 Area had five radioactive emission discharge points active during 2000 at the Fast Flux Test Facility, Maintenance and Storage Facility, and Fuels and Materials Examination Facility.

During 2000, the 600 Area had two radioactive emission points active, both at the Waste Sampling and Characterization Facility.

\section{Sampling Near Facilities}

Air sampling near facilities was conducted within $\sim 500$ meters (1,500 feet) of sites and/or facilities having the potential for, or history of, environmental releases, with an emphasis on the prevailing downwind directions. Samples were collected by a network of continuously operating samplers at 85 locations.
In general, radionuclide concentrations in most air samples were at or near background levels. In 2000, consistently detectable radionuclides were strontium-90, uranium-234, -235, and -238, and plutonium-239/240. Strontium-90 and uranium levels were slightly lower than levels detected in 1999. 


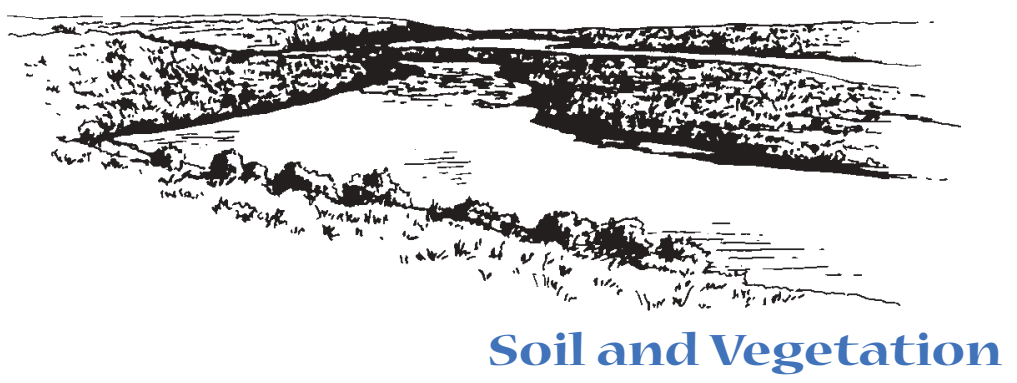

Near-facility soil and vegetation sampling is conducted to detect the potential migration and deposition of facility effluents and emissions. In 2000, 91 soil samples and 75 vegetation samples were collected for analysis. The samples were collected on or adjacent to waste disposal sites and from locations downwind and near or within the boundaries of operating facilities and remedial action sites.

Cobalt-60, strontium-90, cesium-137, plutonium239/240, and uranium were detected consistently in soil and vegetation samples collected in 2000 . The concentrations of these contaminants were elevated near and within facility boundaries when compared to historical concentrations measured off the Hanford Site. The levels show a large degree of variance; in general, samples collected on or adjacent to waste disposal facilities had significantly higher concentrations than those collected farther away.

\section{Investigative Sampling}

Investigative sampling took place near facilities such as storage and disposal sites to detect potential migration and deposition of facility effluents. Samples helped to determine the effectiveness of cleanup measures and programs. Investigative samples collected in 200 included small animals, feces, soil, and vegetation, primarily tumbleweed fragments.

There were 66 instances of contaminated vegetation in 2000 investigative samples. This is an improvement from the 94 detected in 1999. Improved techniques to control vegetation growth and improved administrative procedures were the reason for the decrease.

In 2000, 12 wildlife and wildlife-related samples were collected, 8 of which were submitted for analyses. The maximum levels of radionuclide concentrations were found in mouse feces in the 200-West Area. Contaminants included cobalt-60, strontium-89/90, europium-154, europium-155, plutonium-238, and plutonium-239/240.

\section{Environmental Surveillance Sampling Onsite and in Nearby/Distant Communities}

Radioactive materials in air were sampled at 45 operating locations: 24 on the Hanford Site, 11 near the site perimeter, 8 in nearby communities, and 2 in distant communities. Nine locations were community-operated environmental surveillance stations managed and operated, since 1990, by local teachers.

Atall locations, particulates were filtered from the air and analyzed for radionuclides. Air was sampled and analyzed for selected airborne radionuclides at key locations. Several radionuclides released at the site also are found worldwide from two other sources: naturally occurring radionuclides and radioactive fallout from historical nuclear activities not associated with Hanford operations. The potential influence of emissions from site activities on local radionuclide concentrations was evaluated by comparing differences between concentrations measured at distant locations within the region and concentrations measured at the site perimeter.

In 2000, the annual average gross alpha air concentrations measured at the Hanford Site perimeter and those measured at distant community locations were similar to values reported from 1995 through 1999. The site perimeter annual average gross beta air concentration was slightly higher than distant community concentrations; however, the difference was not statistically significant.

Annual average atmospheric tritium concentrations for 2000 at the Hanford Site perimeter were not significantly different than annual average concentrations at the distant community locations. As a result of research and development activities in 300 Area facilities, annual average tritium concentrations in air in the 300 Area in 2000 were slightly elevated when compared to concentrations measured at other onsite locations. 


\section{Surface Water, Sediment, and Drinking Water}

Samples of surface water and sediment on and around the Hanford Site are collected and analyzed to determine the potential impact to the public and the aquatic environment from Hanford-originated radiological and chemical contaminants.

Surface water bodies include the Columbia River and its associated riverbank springs, onsite ponds, and an offsite irrigation canal. The quality of drinking water on the Hanford Site also is monitored routinely. Samples are collected and analyzed. The data are then compared with established federal and state drinking water standards and guidelines.

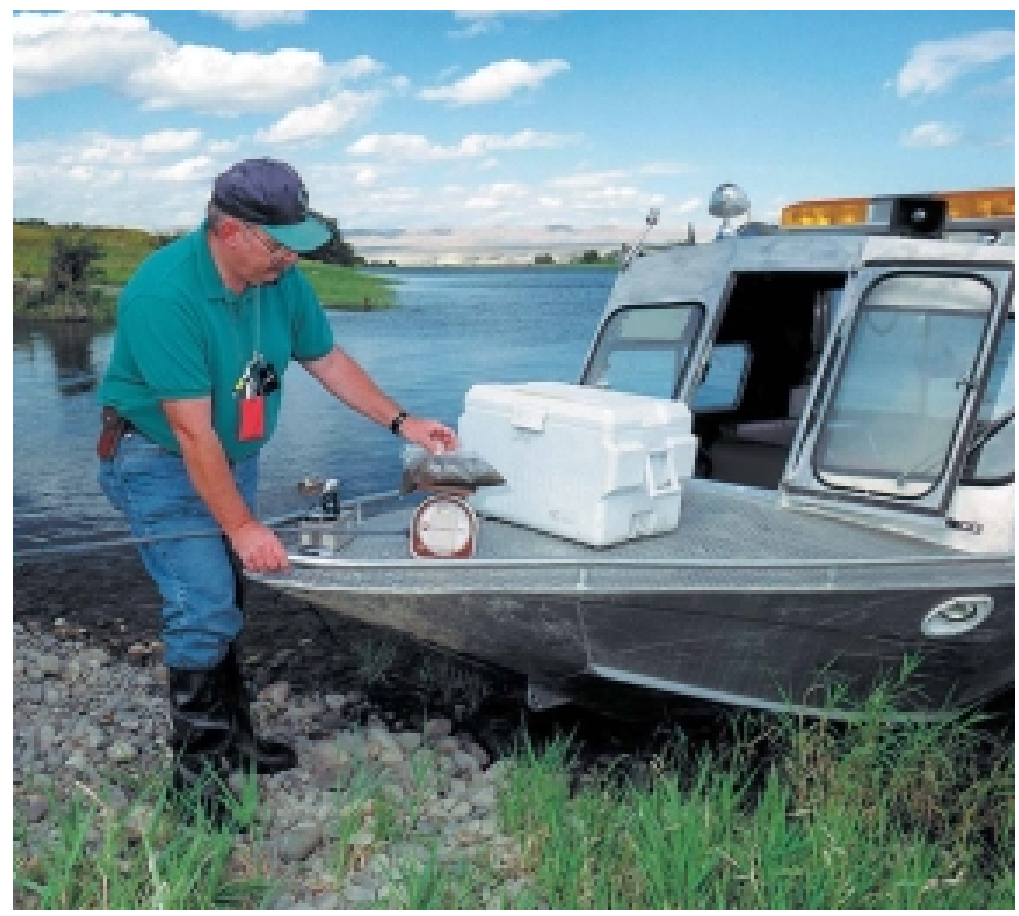

Scientists sample and analyze sediment from the Columbia River for radiological and chemical contaminants.

\section{Columbia River}

Radiological and chemical contaminants entered the Columbia River along the Hanford Reach through 1) seepage of groundwater contaminated from past operations, and 2) permitted, direct-discharges of liquid effluents from Hanford facilities. Water samples were collected from the river at various locations throughout the year and analyzed to determine compliance with applicable water quality standards.

All radiological contaminant concentrations measured in Columbia River water in 2000 were less than DOE derived concentration guides and Washington State ambient surface-water quality criteria levels. The concentrations of tritium and iodine- 129 were significantly higher (5\% significance level) at the Richland Pumphouse (downstream from the site) than at Priest Rapids Dam (upstream from the site), indicating a contribution along the Hanford Reach.
Transect (multiple samples collected across the river) and near-shore sampling in 2000 revealed slightly elevated tritium levels along the Benton County shoreline near the 100-N Area, Old Hanford Townsite, 300 Area, and Richland Pumphouse.

Total uranium concentrations were elevated along the Franklin County shoreline near the 300 Area and the Richland Pumphouse and likely resulted from groundwater seepage and water from irrigation return canals on the east shore of the river that contained naturally occurring uranium. Slightly elevated strontium-90 concentrations were detected in water samples collected at near-shore locations at the 100-N Area.

Several metals and anions were detected in transect samples collected upstream and downstream of the site.

Nitrate, sulfate, and chloride concentrations were slightly elevated, compared $\cdots$. 


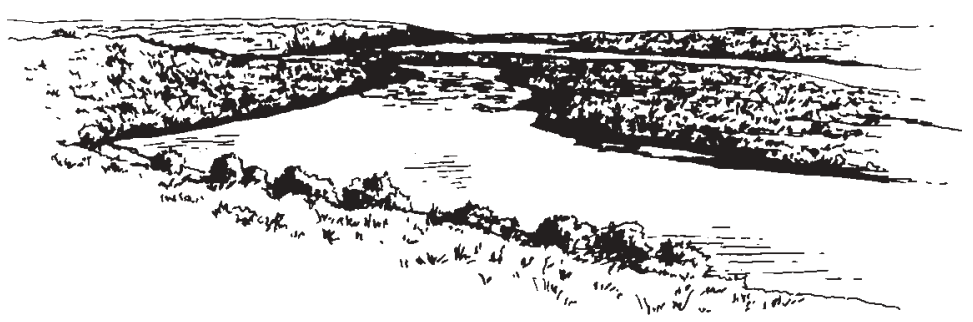

to mid-river samples, along the Franklin County shoreline at the Richland Pumphouse transects and likely resulted from groundwater seepage associated with extensive irrigation north and east of the Columbia River. All metal and anion concentrations (including arsenic) in Columbia River water collected in 2000 were less than Washington State ambient surface-water quality criteria levels. Arsenic concentrations exceeded EPA standards; however, similar concentrations were found at the Vernita Bridge (background location) and the Richland Pumphouse.

In 2000, samples of Columbia River surface sediment were collected above McNary Dam (downstream of the site), above Priest Rapids Dam (upstream of the site), and along the Hanford Reach (including some riverbank springs). In addition, sediment samples were collected above Ice Harbor Dam on the Snake River.

Strontium-90 was the only radionuclide to exhibit consistently higher median concentrations at McNary Dam compared to the other locations. In 2000, no other radionuclides measured in sediment exhibited appreciable differences in concentrations between locations. The concentrations of radionuclides in sediment collected from riverbank springs were comparable to levels detected in 2000 river sediment samples.

Detectable amounts of most metals were found in all river sediment samples with similar levels in riverbank spring sediment. Maximum and median concentrations of most metals in river sediment were higher in sediment collected at Priest Rapids Dam compared to either Hanford Reach or McNary Dam sediment. Metal concentrations in riverbank spring sediment samples in 2000 were similar to concentrations in Columbia River sediment samples from the Hanford Reach.

\section{Riverbank Spring Water}

Water samples were collected from eight Columbia River shoreline spring areas along the Hanford
Site in 2000. All concentrations of radiological contaminants measured in riverbank spring water were less than the DOE derived concentration guides. However, the spring at the 100-N Area that historically has exceeded the DOE derived concentration guide for strontium-90 was not flowing during the 2000 sampling effort.

Tritium concentrations at the Old Hanford Townsite and gross alpha concentrations at the 300 Area riverbank springs exceeded the applicable Washington State ambient surface-water quality criteria. Gross beta concentrations at the Old Hanford Townsite and 300 Area riverbank springs were close to the state criteria. Currently, there are no ambient surface-water quality criteria levels directly applicable to uranium; however, total uranium exceeded the site-specific proposed EPA drinking water standard in the 300 Area riverbank spring. All other radionuclides were below the Washington State ambient surface-water quality criteria levels.

Non-radiological contaminants measured in riverbank springs located on the Hanford shoreline in 2000 were below Washington State ambient surface-water acute toxicity levels, except for chromium in the 100-B, 100-D, 100-F, 100-H, 100-K, 100-N, and 300 Areas riverbank springs. Arsenic concentrations in water from riverbank springs water were well below the applicable state ambient surface-water chronic toxicity levels, but concentrations in all samples exceeded the federal limit. Nitrate concentrations at all locations were below the EPA drinking water standard.

\section{Onsite Pond Water}

Water was collected from two onsite ponds located near operational areas in 2000. Although the ponds were not accessible to the public and did not constitute a direct offsite environmental impact during the year, they were accessible to migratory waterfowl and other animals, creating a potential biological pathway for the dispersion of contaminants. 
With the exception of uranium-234 and uranium-238 in water samples from West Lake, radionuclide concentrations in the onsite pond water were below the DOE derived concentration guides. The median gross alpha, gross beta, and total uranium concentrations in West Lake exceeded applicable ambient surface-water quality criteria levels. Concentrations of most radionuclides in water collected from onsite ponds in 2000 were similar to those detected from 1995 through 1999.

\section{Irrigation Canal}

Irrigation water from the Riverview Canal near Pasco was sampled three times in 2000 to determine radionuclide levels. Water in this canal was obtained from the Columbia River downstream of the Hanford
Site. Radionuclide concentrations in the Riverview irrigation water were below both the DOE derived concentration guides and ambient surface-water quality criteria levels and were similar to those observed in Columbia River water.

\section{Drinking Water}

Radiological surveillance of Hanford Site drinking water was conducted to verify the quality of water supplied by site drinking water systems and to comply with regulatory requirements. During 2000, radionuclide concentrations in Hanford Site drinking water were similar to those observed in recent years and were in compliance with Washington State Department of Health and EPA drinking water standards.

\section{Food and Farm Products}

The Hanford Site is situated in a large agricultural area that produces a wide variety of food and farm products. In 2000, milk, vegetables (tomatoes and potatoes), leafy vegetables (cabbage and beet tops), fruits (apples), hops, and wines were collected from several areas around the site. Samples were collected primarily from downwind directions (south and east of the site) where airborne effluents or fugitive dust from the Hanford Site could be deposited. Samples also were collected in generally upwind directions and at locations somewhat distant from the site to provide information on background radioactivity. Samples were analyzed for gamma emitters (cesium- 137 , cobalt- 60 , strontium-90, iodine-129) and tritium.

Measurable levels of cesium-137, strontium-90, and other manmade gamma-emitting radionuclides were not detected in apples in 2000.

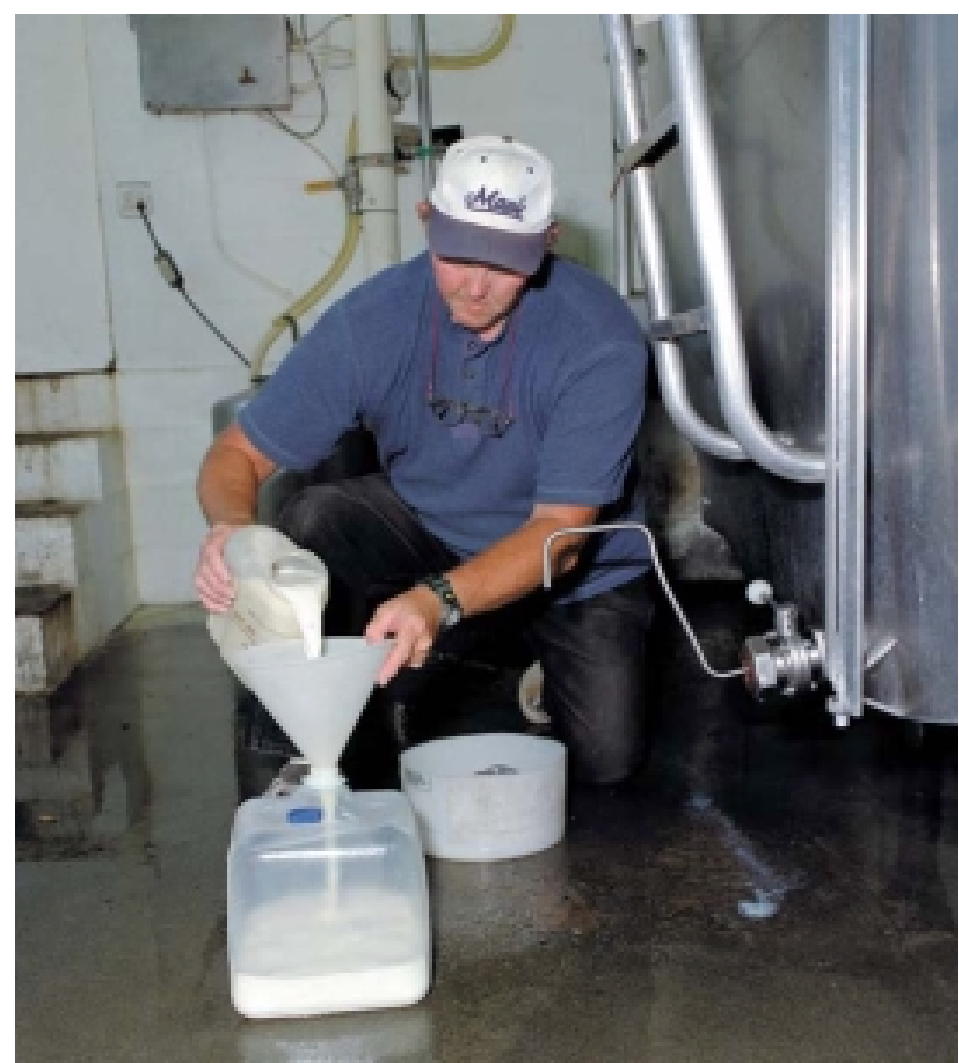

Milk samples were collected from seven dairies around the Hanford Site and analyzed for contaminants. 


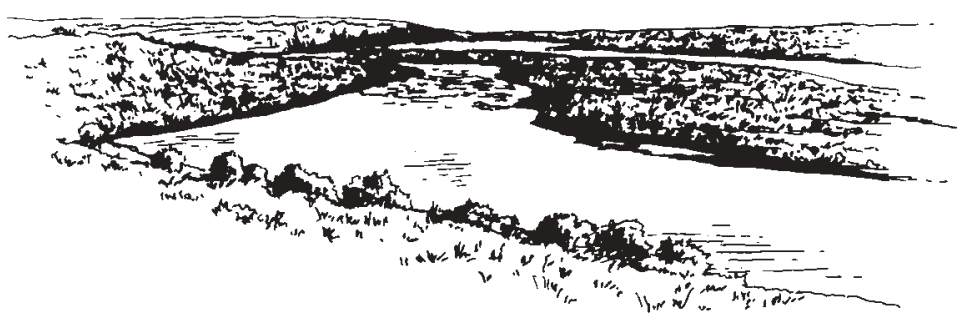

Strontium-90 was detected in two of three leafy vegetable samples from an upwind and a downwind location. Results from both locations were similar. There were no gamma-emitting radionuclides detected in vegetable samples.

The only radionuclide detected in hop samples was potassium-40, a naturally occurring radionuclide.

Iodine-129, strontium-90, and tritium were measured in milk samples. Levels of iodine-129 in milk collected at downwind locations have remained relatively stable for the last 5 years and were slightly higher than levels measured upwind in Sunnyside.
Strontium-90 was detected in 3 of 12 milk samples analyzed in 2000, and the results were close to the analytical detection limit. Tritium concentrations in milk samples were believed to be influenced by the source of water used by the dairies. Tritium levels were low in all samples but were higher in the Sagemoor area compared to milk from both Wahluke and Sunnyside areas.

Tritium levels in all red and white wines were low, with concentrations in Yakima Valley wines lower when compared to concentrations in Columbia Basin wines.

\section{Fish and Wildlife}

Contaminants in fish and wildlife that inhabit the Columbia River and Hanford Site are monitored because: wildlife have access to areas of the site containing radioactive or chemical contamination, and fish can be exposed to contamination entering the river along the shoreline.

Fish and some wildlife species exposed to Hanford contaminants might be harvested for food and may potentially contribute to offsite public exposure. However, the amount of radiological contamination measured in fish and wildlife samples is well below levels known to cause adverse health effects.

Columbia River carp were collected from two areas near Hanford in 2000 and from a background site 80 kilometers ( 50

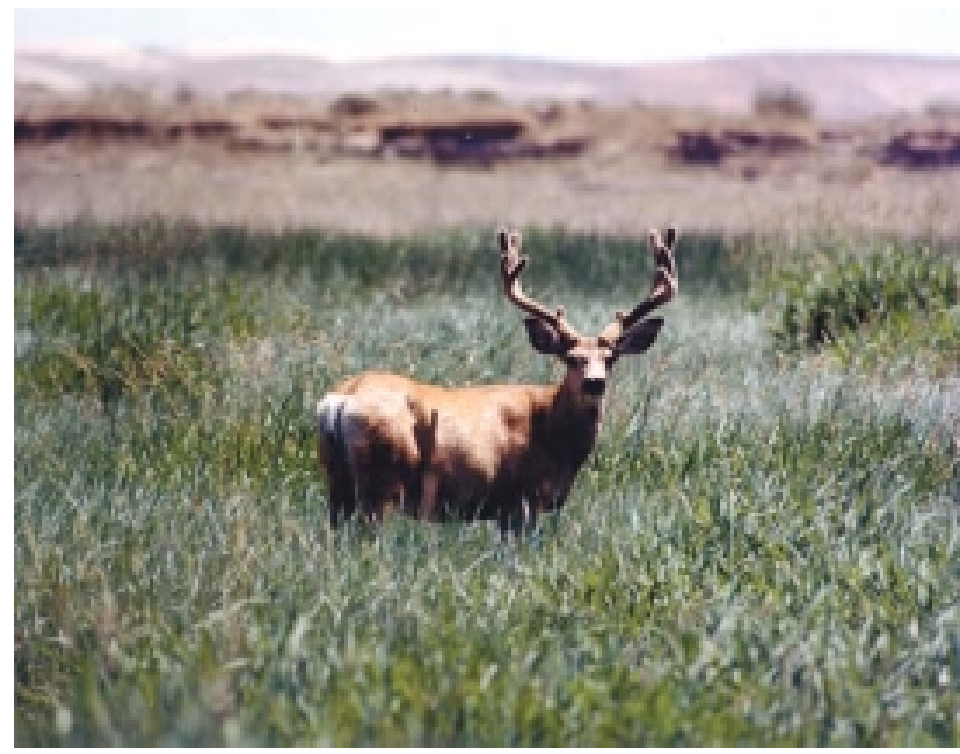

Wildlife sampled and analyzed in 2000 for radioactive constituents included elk, mule deer, pheasant, and quail. Samples were analyzed for gamma emitters, strontium-90, and isotopic plutonium. Some samples were analyzed for isotopic uranium. miles) upstream from Hanford. Cesium-137 was not detected in any of the 14 muscle samples analyzed.

Strontium-90 was found in 9 of 14 carcass samples, but levels were similar to those observed in background fish. However, the strontium-90 concentration in one Hanford Reach carp sample was ten times greater than the median concentrations from all three sampling areas and seven times greater than the highest value reported from the background area. This maximum amount near the 100-N Area indicates some fish have consumed items containing elevated amounts of strontium-90.

In 2000, 10 pheasants, four quail, seven deer, and three elk samples were submitted for analysis. 
None of the pheasant, quail, deer, or elk samples contained detectable amounts of cesium-137. Two of 14 upland game bone samples had strontium-90 concentrations above the analytical detection limit. Strontium-90 was also detected in all seven deer bone samples collected and analyzed in 2000. In the elk samples, concentrations of all manmade radionuclides were reported at or below analytical detection limits with the exception of strontium-90, which was found at low levels in all three samples.
Samples of American avocets (3) and black fly larvae and adults were collected from West Lake, a small pond near the 200 Areas, and analyzed for uranium. West Lake historically has had elevated uranium concentrations in sediment and most unfiltered water samples. Uranium concentrations were highest in black fly larvae, but concentrations in all organisms were low, indicating that there was no "magnification" of uranium through the food chain.

\section{Radiological Surveys and External Radiation}

External radiation also is surveyed on the Hanford Site. External radiation is defined as radiation originating from a source external to the body. External radiation consists of a natural component and a manmade component, which includes radionuclides generated for or from nuclear medicine, power, waste management, and consumer products containing nuclear materials (such as home smoke detectors).

In 2000, environmental external radiation exposure rates were measured by placing thermoluminescent dosimeters and pressurized ionization chambers at selected locations on and off the Hanford Site. External radiation and surface contamination surveys at specified locations were performed with portable radiation survey instruments.

Thermoluminescent dosimeters were positioned 1 meter ( 3 feet) above the ground at 29 locations on the site; 21 distant, community, and perimeter locations; and 26 locations along the Benton County shore of the Columbia River from Vernita to the mouth of the Yakima River. Ground contamination surveys were also conducted quarterly at 13 shoreline locations. These measurements were made to estimate radiation exposure levels attributed to sources on the Hanford Site, to estimate levels along the Hanford Reach shoreline, and to help assess exposure to onsite personnel and offsite populations. Pressurized ionization chambers were situated at four community-operated monitoring stations. Real-time exposure rate data were displayed at each of the four stations to provide information to the public and to serve as an educational tool for the teachers who manage the stations.

The highest dose rates measured in 2000 were along the shoreline near the $100-\mathrm{N}$ Area and were $\sim 1.4$ times the typical shoreline dose rate. These higher rates measured along the 100-N Area shoreline have been attributed to past waste management practices in that area (i.e., disposal of liquid wastes to trenches located near the river shoreline). In 2000, the maximum annual shoreline dose rate was 131 millirem per year, which was not significantly different from the maximum measured in 1999, but was significantly lower than the 5-year maximum of 187 millirem per year. However, exposure levels of this magnitude did not significantly add to dose rates for the public or Hanford workers in 2000.

Geiger counters and microrem meters were used to perform radiological surveys at selected Columbia River shoreline locations. The surveys showed that radiation levels at the selected locations were comparable to levels observed at the same locations in previous years.

Exposure rates measured at four offsite locations with pressurized ionization chambers were consistently between 8.0 and 8.9 microroentgen per hour near Hanford and 7.7 and 8.3 microroentgen per hour in Toppenish, a distant community location. 


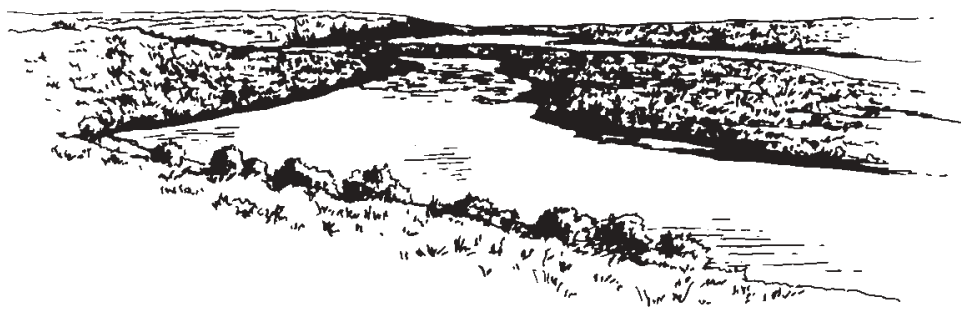

\section{The 2000 Hanford Site Wildfire}

In summer 2000, a wildfire extensively burned approximately 66,400 hectares (164,000 acres) on federal, state, and private lands. None of the site's operational facilities burned, but the fire approached the boundaries of the 200 Areas. Air samples were collected during and after the fire. Post-fire monitoring included collection of soil, ash, farm product, and natural vegetation samples on and around the site. The impact to biological and cultural resources was assessed, and soil stabilization and revegetation efforts were initiated.

Air sampling indicated increased levels of strontium-90 and gross alpha and beta in samples collected in the 200 Areas during the fire. Plutonium levels appeared elevated in five onsite surveillance samples, and uranium-238 levels were elevated at one onsite and one offsite

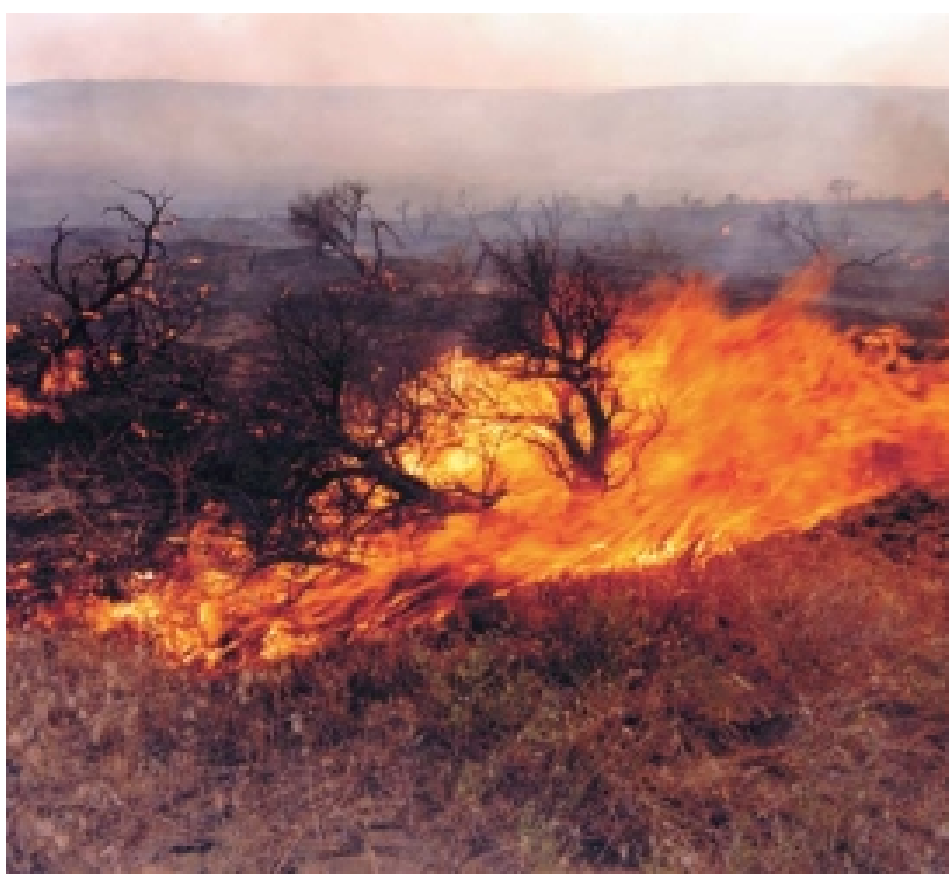

A wildfire began Tuesday afternoon (June 27) near the Hanford Site's western boundary. The fire burned 66,400 hectares (164,000 acres) of federal, state, and private lands in Benton County, Washington. location following the fire. However, all measurable concentrations were well below regulatory limits.

The EPA also collected air samples in communities near Hanford during the latter stages of the fire. Uranium was detected in all samples at background concentrations. Plutonium-239/240 was detected in five samples from the Tri-Cities area and one sample from Sunnyside. It was reasonable to conclude that the elevated plutonium concentrations in the TriCities samples were attributable to suspended ash and/or dust carried from the 200 Areas by high winds. A relatively high analytical error associated with the Sunnyside plutonium concentrations suggested that the value was very close to the limit of detection.

Special samples of vegetables and milk were collected in the Tri-Cities area following the fire and analyzed for plutonium. All concentrations were at or below detection limits. Plutonium concentrations in soil and perennial vegetation samples collected around the Hanford Site following the fire were all very low. Concentrations in soil collected immediately southeast of the site appeared to be marginally elevated compared to samples from locations north and east of the site. All plutonium-239/240 concentrations in soil samples collected offsite were lower than historical offsite plutonium-239/ 240 concentrations.

Plutonium concentrations in vegetation ash samples from the 200 Areas were low, but higher than concentrations in vegetation ash samples collected at another wildfire near Mabton later in the summer.

The impact of the fire on biological resources appears to be temporary. However, several cultural resources were damaged or destroyed.

Post-fire soil stabilization and revegetation activities were initiated around the 200 Areas to control the movement of dust and ash by winds. 


\section{Groundwater and Vadose Zone}

In 2000, samples were collected from 694 monitoring wells to determine the distribution and movement of existing radiological and chemical constituents in Hanford Site groundwater and to identify and characterize potential and emerging groundwater contamination problems. In addition, hydrogeologic characterization and modeling of the groundwater flow system were used to assess the monitoring network and evaluate the potential impact of groundwater contaminants.

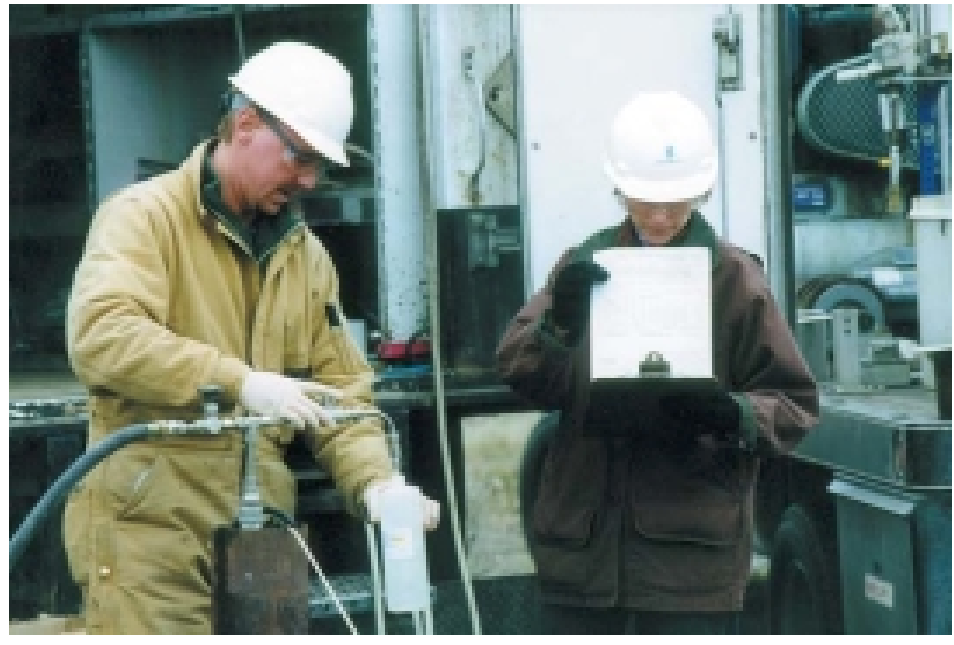

Groundwater monitoring personnel collect samples from across the Hanford Site. in the soil column from past intentional disposal of liquid waste, unplanned leaks, solid waste burial grounds, and underground tanks at the Hanford Site are potential sources of continuing and future groundwater and vadose zone contamination. The vadose zone is the region between the ground surface and the top of the water table. In 2000, subsurface source characterization and vadose zone monitoring, soil-vapor monitoring, sediment sampling and characterization, and vadose zone remediation were conducted to better understand and manage the spread of subsurface contamination.

\section{Groundwater Protection and Monitoring}

To assess the quality of groundwater, measured sample concentrations were compared with EPA drinking water standards and DOE derived concentration guides. Groundwater was used for drinking at one location on the Hanford Site. In addition, water supply wells for the city of Richland are located near the southern boundary of the Hanford Site.

The total area of groundwater contaminant plumes with concentrations exceeding drinking water standards was estimated to be $\sim 231$ square kilo-

meters ( 89 square miles) in 2000 . This area, which is smaller by $\sim 9 \%$ compared to 1999 , occupies $~ 15 \%$ of the total area of the Hanford Site. Most of the contaminant plume area lies southeast of the 200. East Area extending to the Columbia River.

The most widespread contaminants are tritium, iodine-129, technetium-99, uranium, strontium-90, carbon tetrachloride, nitrate, and trichloroethene. Plumes of carbon-14, cesium-137, cobalt-60, and plutonium occur in isolated areas in the 100 and 200 Areas.

Tritium is one of the most widespread contaminants in groundwater across the Hanford Site and exceeded the 20,000-picocuries per liter drinking water standard in portions of the 100,200,400, and 600 Areas. Of these areas, tritium exceeded the 2 million-picocuries per liter derived concentration guide in portions of the 200 and 600 Areas. The highest tritium concentration measured at the Hanford Site in 2000 was 8.38 million picocuries per liter near the 618-11 burial ground, located near the Energy Northwest site. Tritium levels are expected to decrease because of dispersion and radioactive decay. 


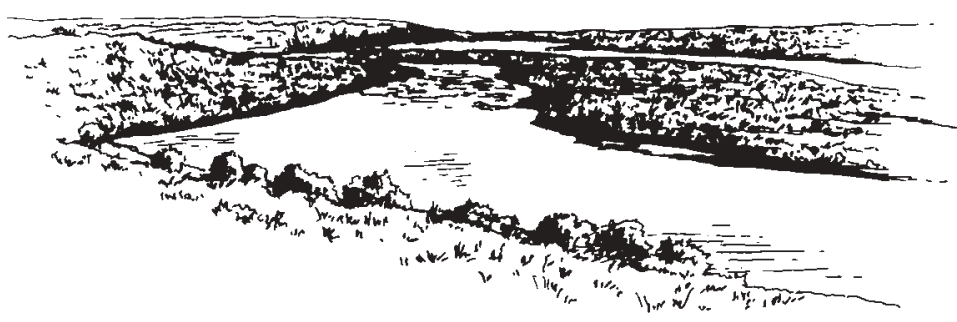

Nogroundwater samples showed iodine-129 concentrations above the 500-picocuries per liter derived concentration guide in 2000 . However, the iodine129 plume at levels exceeding the drinking water standard ( 1 picocurie per liter) is extensive in the 200 and 600 Areas. At the Hanford Site, the highest level of iodine-129 detected in 2000 was 63.9 picocuries per liter near the T, TX, TY tank farms in the 200-West Area. maximum concentration detected was 17,700 picocuries per liter.

Carbon-14 concentrations occur in the $100-\mathrm{K}$ Area and exceed the 2,000-picocuries per liter drinking water standard in two small plumes near the KE and KW Reactors. The maximum concentration in 2000 was 16,300 picocuries per liter near a former KE Reactor waste disposal crib.

Technetium99 was found at concentrations greater than the 900 -picocuries per liter drinking water standard in the 200East and 200-West Areas. The highest level measured on the Hanford Site in 2000 was 72,300 picocuries per liter near the SX tank farm in the 200. West Area.

Total uranium has been detected

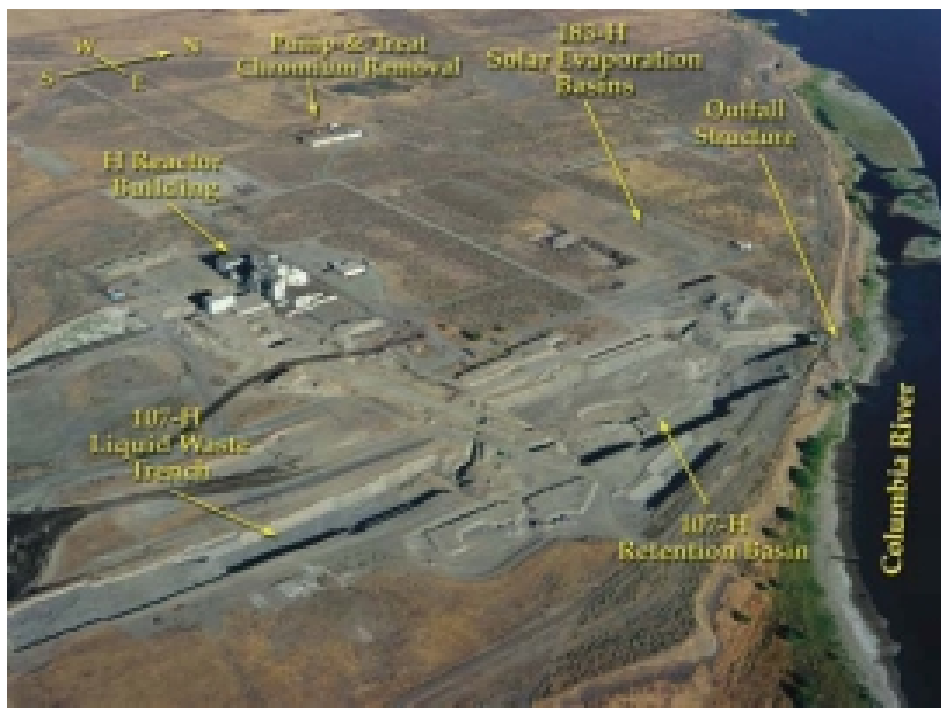

The presence of chromium in groundwater beneath the 100-H Area is a concern because the adjacent riverbed is used by salmon for spawning. A pump-and-treat system currently is operating to reduce the rate at which chromium enters the Columbia River.
Cesium-137 was detected in three wells located near the inactive 216-B-5 injection well in the 200-East Areaandappears to be restricted to this area. Normally, cesium- 137 is strongly sorbed on soil and, thus, is not very mobileingroundwater.

Cobalt-60 was detected in the northwestern part of the 200-East Area and the adjacent 600 Area north of the 200 . greater than the drinking water standard in portions of the 100,200,300, and 600 Areas. The highest level detected at the Hanford Site in 2000 was in the 200. West Area near U Plant, where the uranium level was 1,900 micrograms per liter and exceeded the derived concentration guide.

In 2000 , strontium-90 concentrations greater than the 8-picocuries per liter drinking water standard were found in one or more wells in the 100,200, and 600 Areas. Levels of strontium-90 exceeded the 1,000-picocuries per liter derived concentration guide in the 100-K and 100-N Areas. The 100-N Area had the widest distribution with the highest concentrations detected at the Hanford Site during 2000. The
East Area. The maximum concentration measured in 2000 was 78.4 picocuries per liter at the BY cribs. This concentration was below the 100-picocuries per liter drinking water standard and the 5,000-picocuries per liter derived concentration guide.

Several non-radioactive chemicals regulated by EPA and Washington State also were present in Hanford Site groundwater. These were carbon tetrachloride, chloroform, chromium, cyanide, fluoride, nitrate, tetrachloroethene, cis-1,2-dichloroethene, and trichloroethene. Of these chemicals, nitrate, chromium, and carbon tetrachloride were the most widely distributed in Hanford Site groundwater. 
Nitrate is the most widespread chemical contaminant in Hanford Site groundwater. In 2000, it was measured at concentrations greater than the drinking water standard (45 milligrams per liter) in portions of the 100, 200, and 600 Areas. The maximum nitrate concentration measured on the Hanford Site in 2000 was 1,213 milligrams per liter in the 200. West Area.

Chromium was detected above the drinking water standard in 2000 at the 100-D, 100-F, 100-H, 100-K, 100-N, 200-East, and 200-West Areas. The maximum detected concentration was 3,250 micrograms per liter in a 200-East Area well near the $\mathrm{A}$ and AX tank farms. In the hexavalent form, chromium is very mobile in groundwater.

Carbon tetrachloride contamination occurs above the 5-milligrams per liter drinking water standard in much of the 200-West Area and represents one of the most significant contaminant plumes at the Hanford Site. The plume, which covers an area more than 11 square kilometers (4 square miles), extends past the 200-West Area boundary into the 600 Area. Carbon tetrachloride has been found to have a high degree of mobility in groundwater. The highest concentration measured in 2000 was 7,100 micrograms per liter near the Plutonium Finishing Plant in the 200-West Area.

The highest chloroform concentrations were measured in the vicinity of the Plutonium Finishing Plant in the 200-West Area, where the maximum level was 130 micrograms per liter, above the 100 . micrograms per liter drinking water standard.

In 2000, trichloroethene was detected at levels greater than the 5-micrograms per liter drinking water standard in several wells in the 100,200,300, and 600 Areas. The most widespread area of contamination occurred in the 200-West Area. The highest concentration measured in 2000 was 31 micrograms per liter in a well northeast of the Plutonium Finishing Plant, which is located in the 200. West Area.
The highest levels of cyanide were detected in samples collected from wells in the northwestern part of the 200-East Area and in the 600 Area north of the 200-East Area. The maximum concentration measured in 2000 was 411 micrograms per liter, which is above the 200-micrograms per liter drinking water standard. This concentration was seen in two wells near the inactive BY cribs, near the 200East Area.

Pump-and-treat systems operate in the 100 Areas and 200 West Area for groundwater restoration. The objective of the pump-and-treat systems is to remove contamination in the groundwater and thus minimize any impact to the Columbia River.

\section{Vadose Zone Characterization}

During 2000, one new characterization borehole was drilled and sampled in the 200-West Area to better understand sediment properties, contaminant distribution, and transport mechanisms operating in the vadose zone in a single-shell tank farm. This well was drilled on a slant, 30 degrees from vertical, so that characterization activities could be conducted under the waste tanks. Baseline spectral gamma logging of selected wells in the single-shell tank farms also was completed.

Also in 2000, DOE's Environmental Management Science Program began a 3-year study of clastic dikes and their influence on movement of subsurface contamination. The study was designed to describe the geometric and hydrologic properties of clastic dikes and extrapolate those properties to the subsurface of waste disposal and storage sites. Clastic dikes are common sedimentary structures in the vadose zone at Hanford. Remote sensing and ground-penetrating radar surveys were used to describe the largescale distribution of clastic dikes along Army Loop Road in the 600 Area and at the former 216-S-16 pond near the 200-West Area. Approximately 3,860 dikes were described. 


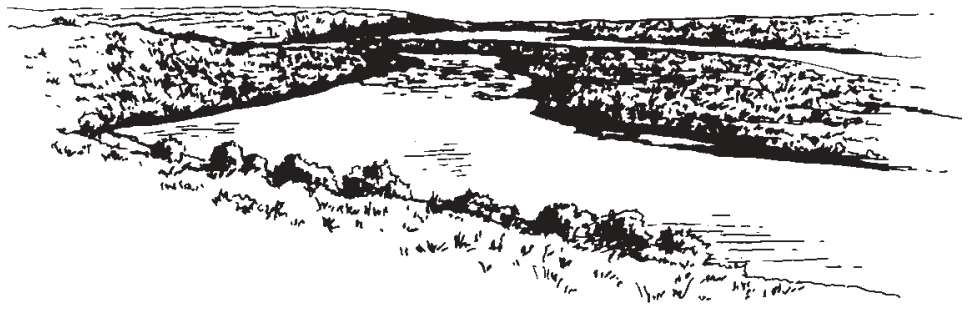

Vadose zone characterization activities were conducted at four locations in the 200 Areas to support remediation of sites that received cooling water waste (the former Gable Mountain Pond and the former B Pondandassociatedditches) and at one site in the 100-D Area to supportchromate remediation using in situ gaseous reduction technology.

Assessments of two proposed immobilized lowactivity waste disposal sites were initiated. Geologic information was compiled, and estimates of recharge rates were made for both current conditions and long-term scenarios. Additionally, the hydrologic data needed to perform farfield vadose zone flow and

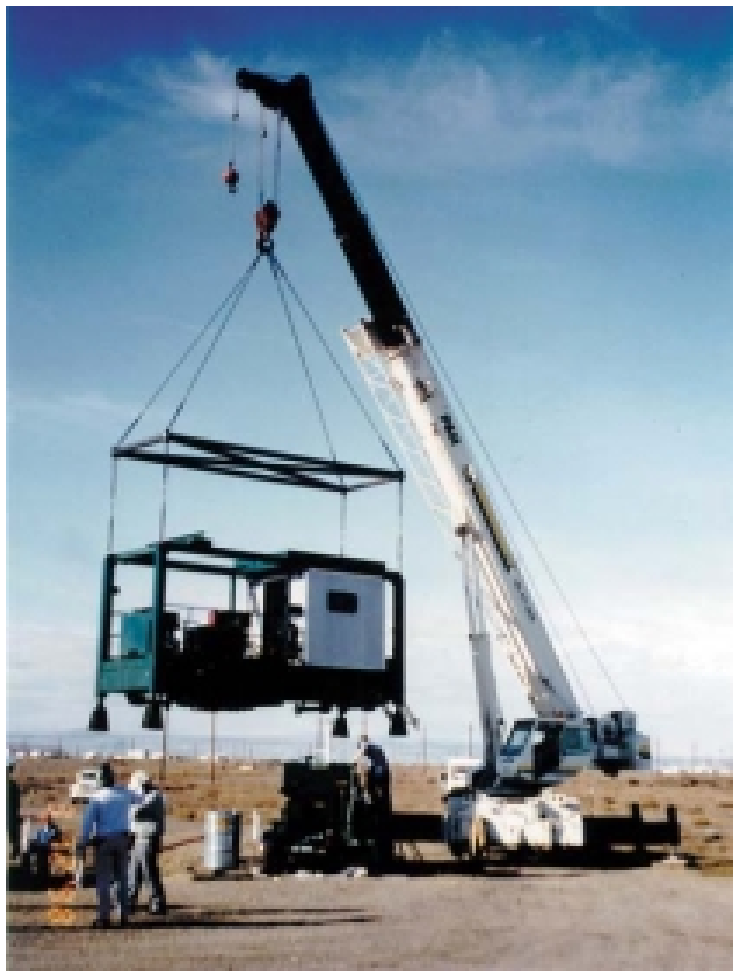

A cone penetrometer being lowered into place at the Hanford Site to push sensors and probes into the soil to gather information about the vadose zone. In January and February 2000, this system was used in the 200-West Area to obtain and analyze soil samples for contamination.

\section{Vadose Zone Monitoring}

Vadose zone monitoring occurred at four sites at Hanford in the year 2000. Leachate and soil gas monitoring continued at the Solid Waste Landfill and the Environmental Restoration Disposal Facility and historical results from the 3-year period 1996 through 1999 were summarized for the Environmental Restoration Disposal Facility.

Soil gas monitoring for carbon tetrachloride continued in the 200-West Area during 2000. Soilvapor concentrations were monitored near the ground surface and groundwater to assess whether non-operation of a soil-vapor extracting system allowed carbon compiled and the geochemical properties of the materials comprising one facility, the disturbed region around the facility, and the undisturbed sediment below the facility were estimated. Fifteen data packages were issued in 2000 to support these assessments.

Large quantities of Ringold and Hanford Formation sediment were collected in 1999 and partially characterized in 2000. Samples were collected in and near the 200 Areas and from the White Bluffs located east of the Columbia River in Franklin County. Only two of the samples were characterized in 2000. The purpose of this effort was to establish well characterized "standards" that can be used by researchers who study problems associated with cleanup of the Hanford Site. tetrachloride to migrate out of the vadose zone. The temporary suspension of soil-vapor extraction in 2000 appears to have caused minimal detectable vertical transport of carbon tetrachloride through the soil surface to the atmosphere. There also appeared to be no negative impact to the groundwater.

Soil gas monitoring was also done at the 618-11 burial ground (near the Energy Northwest site) in response to elevated levels of tritium discovered during 2000. Fifty-four soil-gas sampling points were installed north and east of the burial ground to identify vadose zone or groundwater sources of tritium in the subsurface environment. This is part of an investigation to determine the extent of groundwater contamination at the burial ground. 


\section{Vadose Zone Technical Demonstrations}

Technical demonstrations are designed to develop innovative methods for cleaning up and monitoring the Hanford Site. In 2000, a small-diameter, passive neutron tool was demonstrated to detect subsurface transuranics in the vadose zone under certain conditions. Also, a small-diameter spectral gamma logging tool was demonstrated at an environmental remediation site in the 100 Areas. Both tools could result in substantial cost savings over conventional methods of characterization and monitoring.

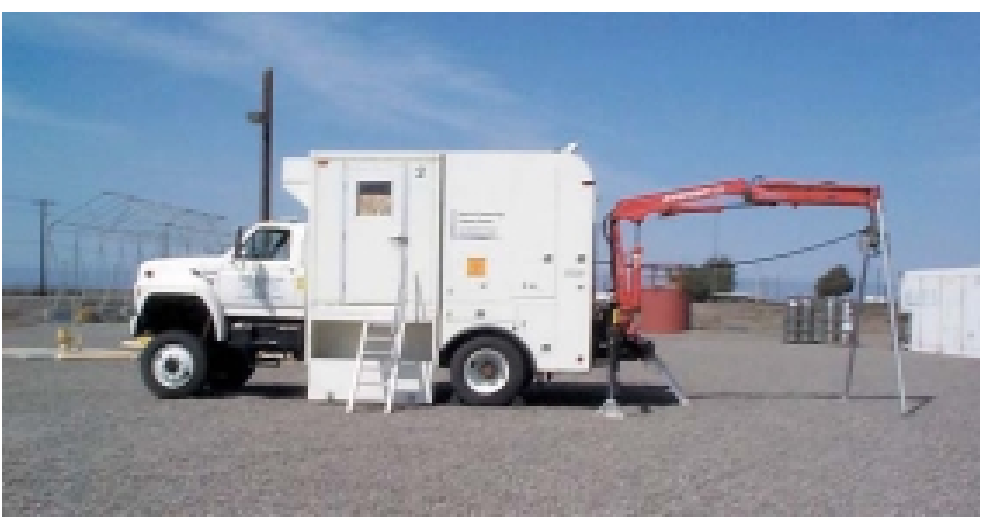

Scientists used a geophysical technique known as spectral gamma logging to determine whether contaminants are moving through the soil. A smalldiameter spectral gamma logging tool was demonstrated in the 100 Areas of the Hanford Site in 2000.

\begin{tabular}{|c|c|c|c|c|}
\hline \multirow[b]{2}{*}{ Location } & \multicolumn{4}{|c|}{$\begin{array}{c}\text { Summary of Groundwater Pump-and Treat Systems } \\
\text { and Soil Vapor Extraction Efforts }\end{array}$} \\
\hline & Start up date & Contaminant & $\begin{array}{l}\text { Mass Removed/ } \\
\text { Groundwater } \\
\text { Processed in } 2000\end{array}$ & $\begin{array}{l}\text { Mass Removed/ } \\
\text { Groundwater } \\
\text { Processed since Startup }\end{array}$ \\
\hline 100-D Area & 1997 & $\begin{array}{l}\text { Hexavalent } \\
\text { chromium }\end{array}$ & $\begin{array}{l}25.3 \text { kilograms/ } \\
135.7 \text { million liters }\end{array}$ & $\begin{array}{l}\text { (Historically, 100-D and } \\
100-\mathrm{H} \text { Areas have been }\end{array}$ \\
\hline 100-H Area & 1997 & $\begin{array}{l}\text { Hexavalent } \\
\text { chromium }\end{array}$ & $\begin{array}{l}4.7 \text { kilograms/ } \\
169.4 \text { million liters }\end{array}$ & $\begin{array}{l}\text { combined for reporting) } \\
\text { 103.1 kilograms/ 959.1 } \\
\text { million liters }\end{array}$ \\
\hline 100-K Area & 1997 & $\begin{array}{l}\text { Hexavalent } \\
\text { chromium }\end{array}$ & $\begin{array}{l}33.5 \text { kilograms/ } \\
286.7 \text { million liters }\end{array}$ & $\begin{array}{l}113.9 \text { kilograms/ } \\
908 \text { million liters }\end{array}$ \\
\hline 100-N Area & 1995 & Strontium-90 & $\begin{array}{l}0.18 \text { curies/ } \\
106 \text { million liters }\end{array}$ & $\begin{array}{l}0.91 \text { curies/ } \\
551.9 \text { million liters }\end{array}$ \\
\hline $\begin{array}{l}200-\text { West } \\
\text { Area (200-ZP-1 } \\
\text { Operable Unit) }\end{array}$ & 1994 & $\begin{array}{l}\text { Carbon } \\
\text { tetrachloride }\end{array}$ & $\begin{array}{l}\text { 1,183 kilograms/ } \\
300.4 \text { million liters }\end{array}$ & $\begin{array}{l}9,570 \text { kilograms/ } \\
1.25 \text { billion liters }\end{array}$ \\
\hline \multirow{4}{*}{$\begin{array}{l}200-\text { West } \\
\text { Area (200-UP-1 } \\
\text { Operable Unit) }\end{array}$} & 1994 & $\begin{array}{l}\text { Carbon } \\
\text { tetrachloride }\end{array}$ & $\begin{array}{l}1.66 \text { kilograms/ } \\
63.2 \text { million liters }\end{array}$ & $\begin{array}{l}17.4 \text { kilograms/ } \\
420.8 \text { million liters }\end{array}$ \\
\hline & 1994 & Nitrate & $\begin{array}{l}\text { 2,807 kilograms/ } \\
63.2 \text { million liters }\end{array}$ & $\begin{array}{l}\text { 15,576 kilograms/ } \\
420.8 \text { million liters }\end{array}$ \\
\hline & 1994 & Technetium-99 & $\begin{array}{l}5.6 \text { grams/ } \\
63.2 \text { million liters }\end{array}$ & $\begin{array}{l}67.3 \text { grams/ } \\
420.8 \text { million liters }\end{array}$ \\
\hline & 1994 & Uranium & $\begin{array}{l}\text { 13.6 kilograms/ } \\
63.2 \text { million liters }\end{array}$ & $\begin{array}{l}114.8 \text { kilograms/ } \\
420.8 \text { million liters }\end{array}$ \\
\hline \multicolumn{5}{|c|}{ Vapor Extraction Systems } \\
\hline 200-West Area & 1992 & $\begin{array}{l}\text { Carbon } \\
\text { tetrachloride }\end{array}$ & $\begin{array}{l}\text { None in } 2000- \\
\text { system in standby mode }\end{array}$ & 76,460 kilograms \\
\hline
\end{tabular}




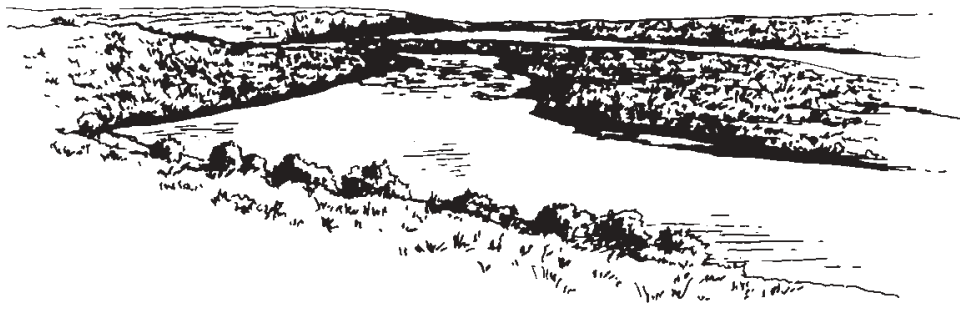

Quality Assurance

Comprehensive quality assurance programs are conducted to ensure data quality. The programs are implemented through quality assurance plans designed to meet requirements of the American National Standards Institute/American Society of Mechanical Engineers and DOE Orders. Quality assurance plans are maintained for all activities, and auditors verify conformance.

Quality control methods include, but are not limited to, replicate sampling and analysis, analysis of field blanks and blind reference standards, participation in interlaboratory cross-check studies, and splitting samples with other laboratories.

Whensample results are received, they are screened for anomalous values by comparing them to recent results and historical data. Analytical laboratory performance on the submitted double-blind samples, the EPA Laboratory Intercomparison Studies Program, and the national DOE Quality Assessment Program indicated that laboratory performance in 2000 was adequate overall, was excellent in some areas, and needed improvement in others.

Pacific Northwest National Laboratory also participated in a Quality Assurance Task Force, a program coordinated by the Washington State Department of Health. Public and private organizations from Idaho, Oregon, Washington, and Georgia participated in analyzing the intercomparison samples in 1999 and 2000.

Quality assurance/quality control for environmental monitoring and surveillance programs also include procedures and protocols to:

- document instrument calibrations

- conduct program-specific activities in the field

- maintain groundwater wells to ensure representative samples were collected

- $\quad$ avoid cross-contamination by using dedicated well sampling pumps.

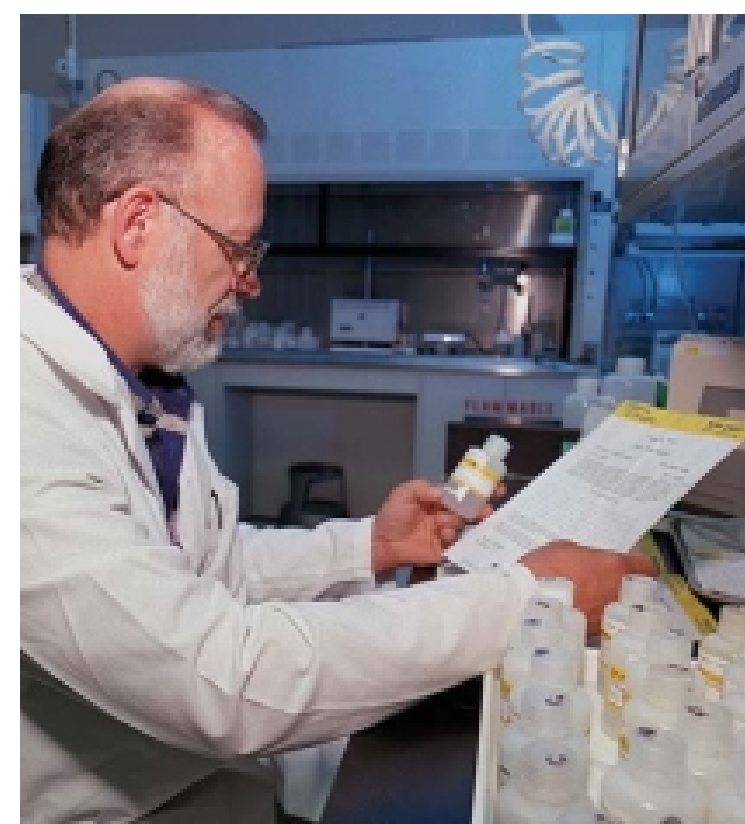

Environmental samples are analyzed by trained staff according to approved and documented procedures.

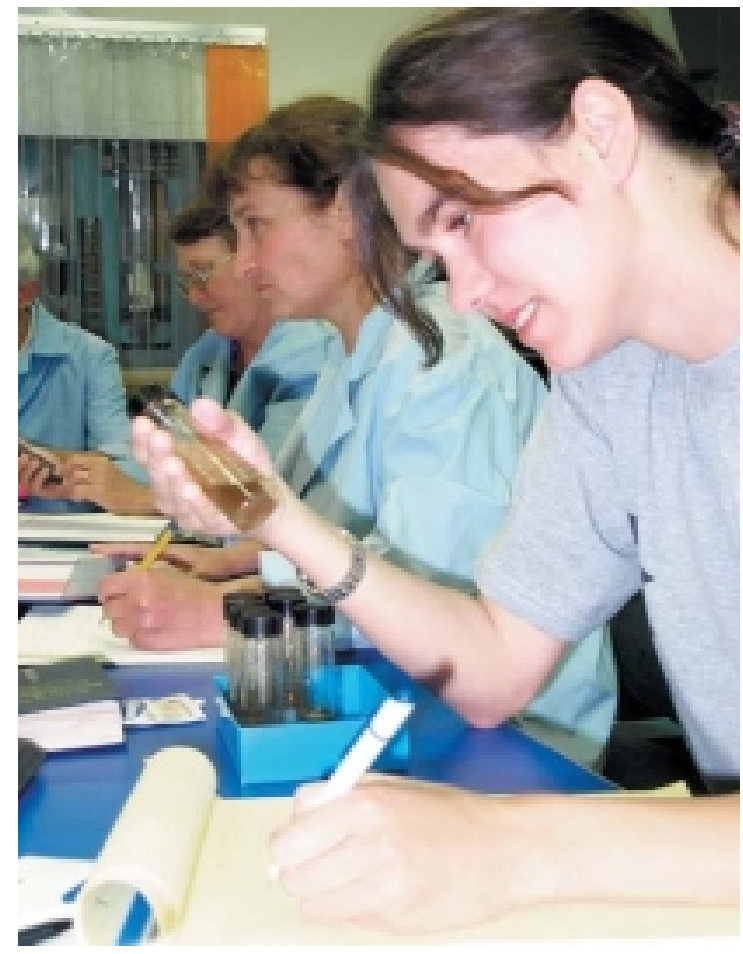

Comprehensive quality assurance programs are maintained to ensure the quality of data collected. 

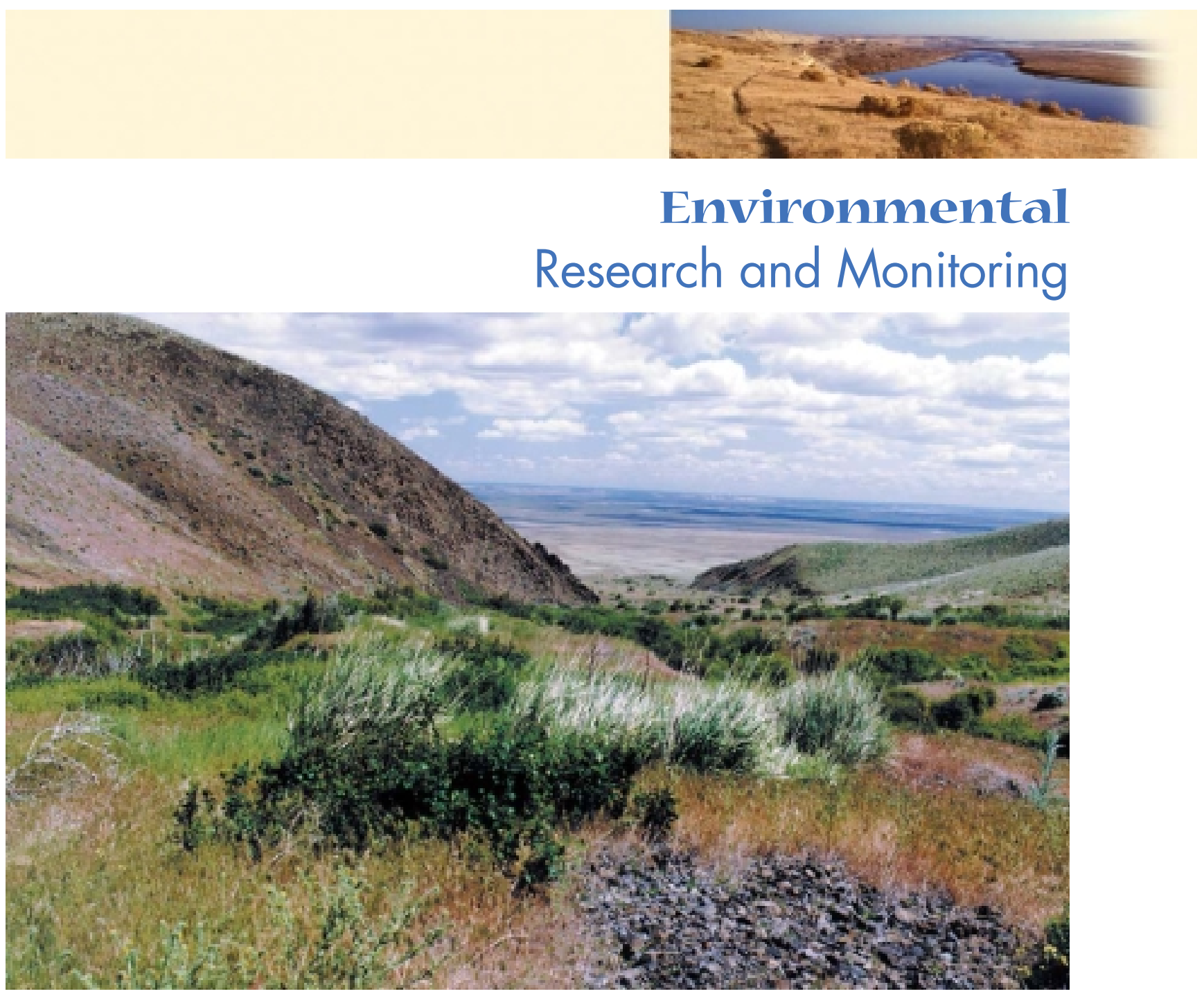

This photo shows the Hanford Site looking east from the Rattlesnake Hills across the Cold Creek Valley. Scientists define the vegetation of this region as shrub-steppe. This vegetation zone is primarily big sagebrush and bluebunch wheatgrass, which cover 3.3 million hectares (8.2 million acres) of the arid interior of eastern Washington.

At the Hanford Site, a variety of environmental and cultural resource activities are performed to comply with laws and regulations, enhance environmental quality, and monitor the impact of environmental pollutants from site operations. Meteorological response is provided around the clock on the site in the event of a suspected or actual release of radioactive or hazardous material to the atmosphere. Comprehensive climatological data records are maintained to use in environmental impact assessment and dose reconstruction.

Scientists monitor the entire Hanford ecosystem and specific plant and animal species and habitats to assess the status of threatened, endangered, or commercially/recreationally important species and habitats and to identify impacts of Hanford Site operations on flora and fauna. Cultural resources on the site also are identified and evaluated to determine impacts from site operations. Historic buildings and structures are evaluated for their historic significance. This section summarizes activities conducted in 2000 to monitor the site's climatology and meteorology, assess the status of ecological monitoring and compliance, and monitor and manage cultural and historic resources. 


\section{Climate and Meteorology}

Meteorological measurements are taken to support site emergency preparedness, site operations, and atmospheric dispersion calculations. Hanford Site meteorologists provide weather forecasting and maintenance and distribution of climatological data. Forecasting is provided to help manage weather-dependent operations. Climatological data are provided to help assess the environmental effects of site operations. Calendar year 2000 was slightly cooler than normal, and precipitation was above normal.

The Hanford Meteorology Station is located on the 200 Areas plateau where the prevailing wind direction is from the northwest during all months. The secondary wind direction is from the southwest. The average wind speed for 2000 was 3.4 meters per second ( 7.5 miles per hour), which was 0.1 meter per second ( 0.2 mile per hour) below normal. The peak gust for the year was 25 meters per second ( 55 miles per hour) on November 4.

There were two dust storms recorded at the Hanford Meteorology Station during 2000. There have been an average of five dust storms per year at the station during the entire period of record (1945-2000).

The average temperature for 2000 was $11.4^{\circ} \mathrm{C}$ $\left(52.6^{\circ} \mathrm{F}\right)$, which was below normal $\left(11.8^{\circ} \mathrm{C}\left[53.3^{\circ} \mathrm{F}\right]\right)$. Precipitation for 2000 totaled 20.5 centimeters $(8.08$ inches), which was above normal ( 15.9 centimeters [6.26 inches]). Snowfall for 2000 totaled 41.9 centimeters (16.5 inches) compared to an annual normal snowfall of 35.1 centimeters (13.8 inches).

\section{Ecosystem Monitoring}

The Ecosystem Monitoring Project monitors the status of plant and animal populations on the Hanford Site, maintains biotic inventory data for the site, and assists in implementing ecosystem management policies. The status of rare plant populations and plant community types, spawning Columbia River fall chinook salmon, wintering bald eagles, nesting buteo hawks, and Rocky Mountain elk are monitored annually as part of the project.

\section{Fall Chinook Salmon}

In 2000, 5,507 fall chinook salmon redds were observed in aerial surveys of the Hanford Reach of the Columbia

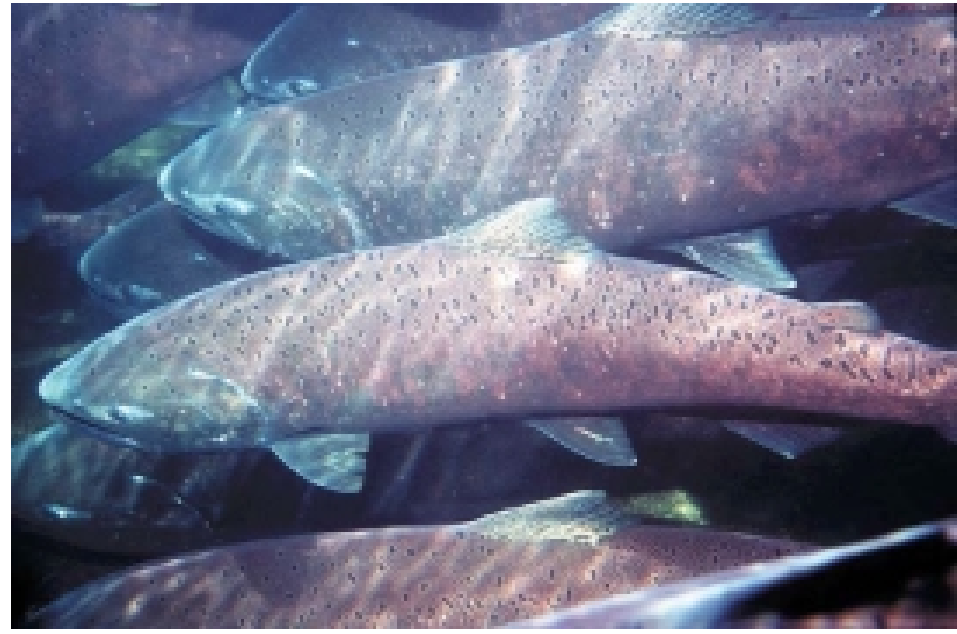

Chinook salmon use the Hanford Reach of the Columbia River as a spawning area in the fall. Surveys in 2000 indicated that the number of fall spawning fish in the Hanford Reach decreased from the 1999 level and was $70 \%$ of the 1996 and 1997 totals.

River, a decrease of 580 from 1999 and

70\% of the 1996 and 1997 totals. Aerial surveys do not yield absolute redd counts because visibility varies, depending on water depth and other factors, and because the number of redds in high-density locations

cannot be counted accurately. However, redd survey data generally agree with adult numbers obtained by counting migrating adult fish at fish ladders on the Columbia River. 


\section{Bald Eagles}

Historically, federally threatened bald eagles have wintered along the Hanford Reach of the Columbia River. The wintering eagles originate from various places, including interior Alaska, British Columbia, the Northwest Territories, Saskatchewan, and possibly Manitoba.

In 2000, five surveys were completed, and a maximum count of 26 eagles (11 adults and 15 juveniles) was observed along the Hanford Reach. This is up from 24 eagles observed in 1999. This maximum count is similar to those seen in the late 1970s and early 1980s and indicates that the low count in 1998 likely reflected changes in food availability near the birds nesting territories, and hence, winter migration patterns.

\section{Hawks}

The undeveloped land of the semiarid areas of the Hanford Site provides nesting sites and food for three species of migratory buteo hawks: Swainson's, red-tailed, and ferruginous. Under natural conditions, these hawks nest in trees, on cliffs, or on the ground. Power-line towers and poles also serve as nest sites. They are used extensively by nesting hawks because of the relative scarcity of trees and cliffs.

The ferruginous hawk is a Washington State threatened species and a U.S. Fish and Wildlife Service candidate species for listing as threatened or endangered. Approximately one quarter of the state's ferruginous hawk nesting territories are located on the site. Since 1995, the number of ferruginous hawks nesting on the Hanford Site has ranged from 7 to 12 . There were 8 active nests in 2000, the same number as in 1999.

The site continues to provide hawk-nesting habitats that are administratively protected from public intrusion. Ferruginous hawks nest on the site because of suitable, disturbance-free habitat, and the proximity of agricultural fields for foraging.

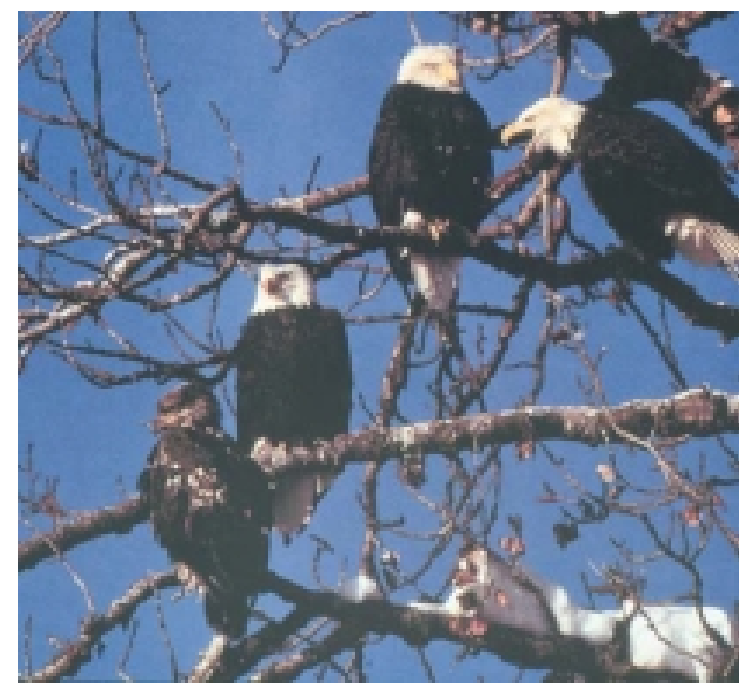

Bald eagles are a frequent winter visitor to the site.

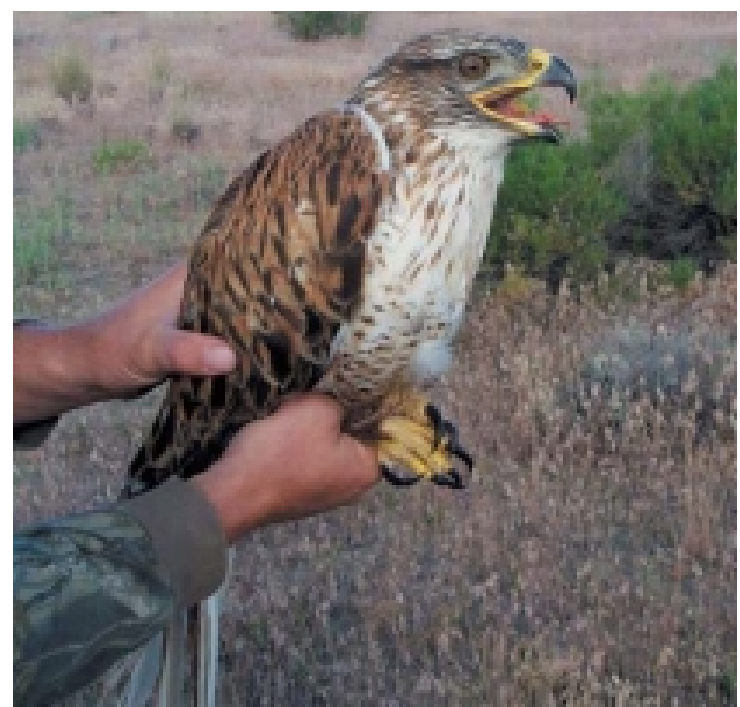

The ferruginous hawk is listed as a state threatened and federal candidate species.

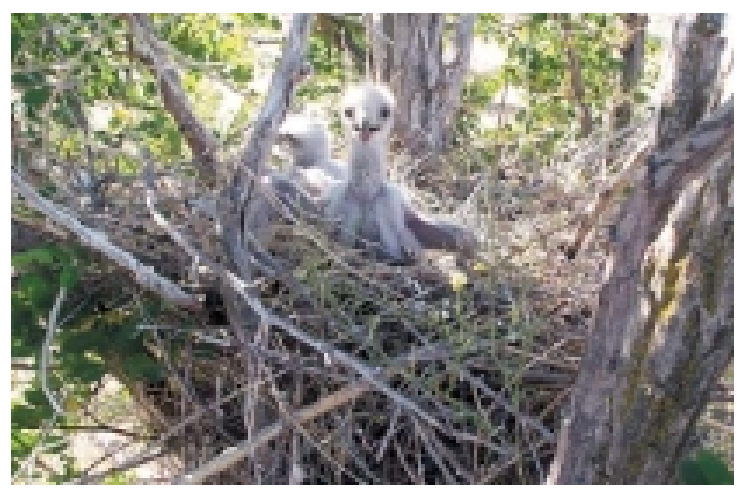

Swainson's hawks are one bird species monitored on the site. 


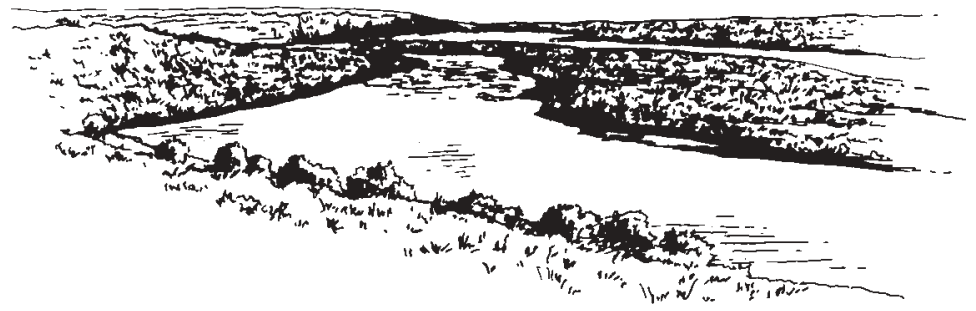

\section{Rocky Mountain Elk}

Rocky Mountain elk were first observed on the Fitzner/Eberhardt Arid Lands Ecology Reserve in 1972. Since that time, the herd has grown and now occupies portions of the Hanford Site, the U.S. Army's Yakima Training Center, and private land along Rattlesnake Ridge.

At the end of 1999 hunting season, the herd size was estimated at 747 animals. A roundup conducted by the U.S. Fish and Wildlife Service and Washington State Department of Fish and Wildlife in mid-March 2000 resulted in the relocation of 171 animals.

In 2000, elk were monitored as part of a special study of the movement and population dynamics of the Rattlesnake Hills elk herd. This work was intended to monitor the population characteristics of the elk herd and provide scientific information to detect any impact Hanford Site operations may have on the Rattlesnake Hills elk population.

\section{Mule Deer}

Since 1993, systematic roadside observations of mule deer have been conducted during the post-hunting periods (December through January). The surveys were conducted to monitor trends in age and sex ratios, examine trends in their relative abundance on the Hanford Site, and monitor the frequency of testicular atrophy.

In 2000, mule deer fawn survival was over 45 fawns per 100 does, which is similar to other deer populations in the shrub-steppe ecosystem.

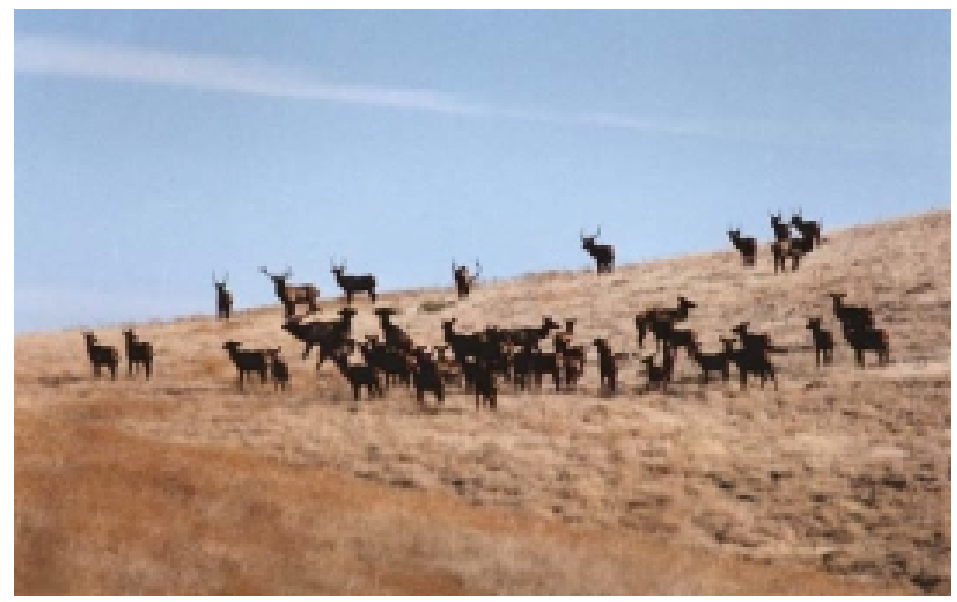

About 747 elk remained on the Hanford Site after the end of the 1999 hunting season.

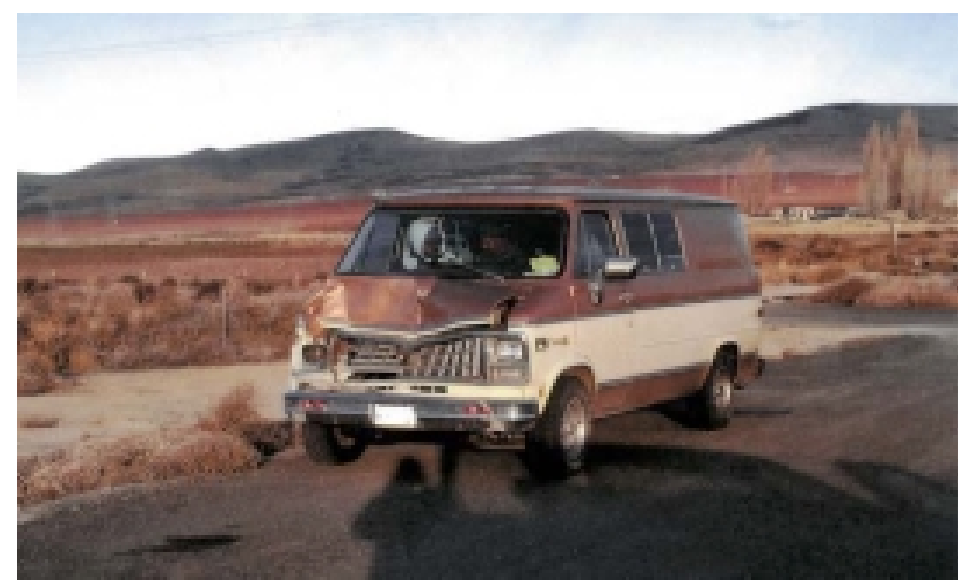

Four elk/vehicle collisions occurred in 2000. The frequency of elk crossing State Highway 240 increased after the wildfire in June 2000.

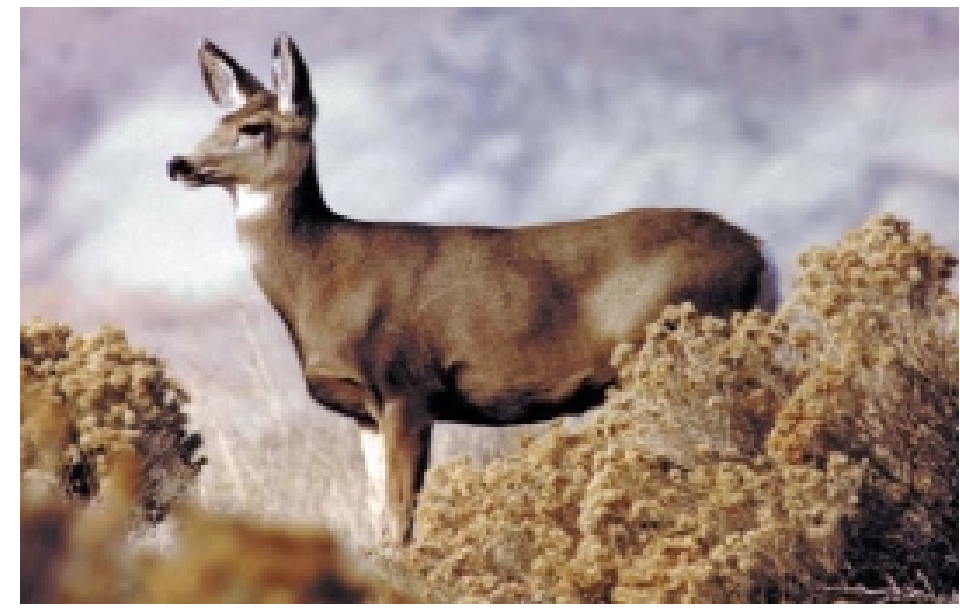

Surveys of mule deer help scientists evaluate the health of the mule deer population. 


\section{Plant Biodiversity Inventories}

The Hanford Site contains biologically diverse shrub-steppe plant communities that have been protected from disturbance, except for fire, over the past 55 years. This has allowed plant species that have been displaced by agriculture and development in other parts of the Columbia Basin to thrive at Hanford. More than 100 rare plant populations are found on the Hanford Site.

In addition to rare plant populations, several areas on the Hanford Site are designated as special habitat types with regard to potential occurrence of plant species of concern. They include areas that could support populations of rare annual forbs that have been documented in adjacent habitat.

Surveys in 2000 continued to indicate increases in the numbers of Piper's daisy, a species of concern occurring in the 200 Areas. Populations of another species of concern occurring near the Columbia River, persistent sepal yellowcress, do not appear to have experienced significant recovery after declining as a result of the high Columbia River flow levels over the past 4 years.

Maps showing the extent and distribution of the plant communities on the Hanford Site are scheduled to be updated in 2001 to reflect the changes in plant communities resulting from the wildfire in June 2000.

Big sagebrush is the most common shrub component of shrub-steppe vegetation on the Hanford Site. Since 1993, areas of sagebrush die-off have been documented in stands near the 100-D Area and the cause has not been determined. To date, no evidence exists suggesting any relationship between Hanford Site operations and sagebrush die-off. Other shrubs, such as hopsage and bitterbrush, with similar deep root systems appear unaffected. Other native species, such as bunchgrass, also appear to remain healthy and vigorous.

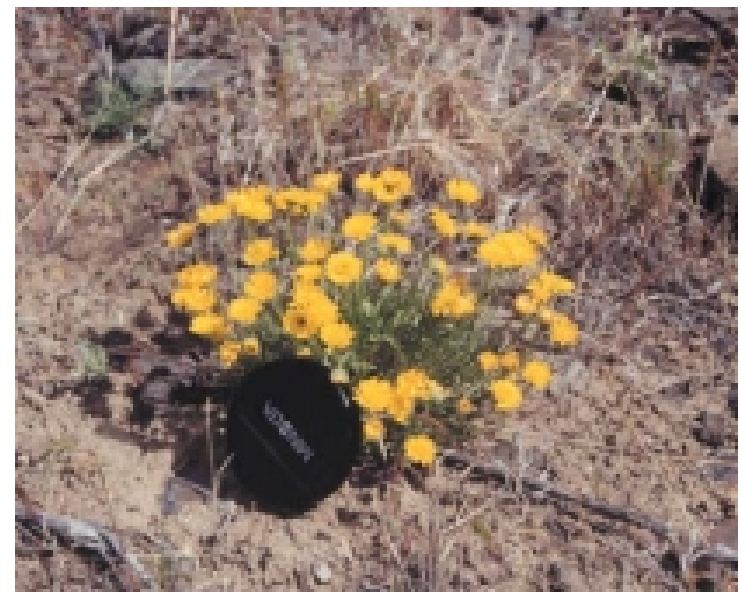

Surveys in 2000 indicated that the numbers of Piper's daisy have increased in the 200 Areas.

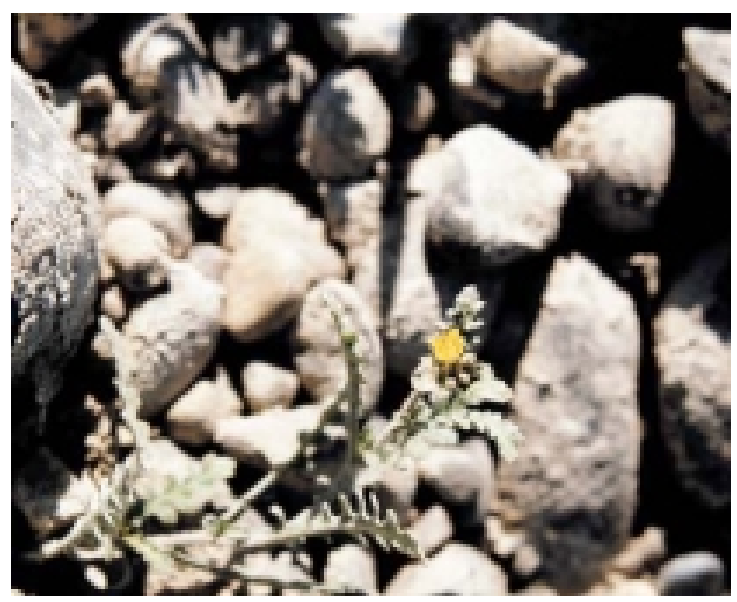

Persistent sepal yellowcress is a species of concern found along the Columbia River.

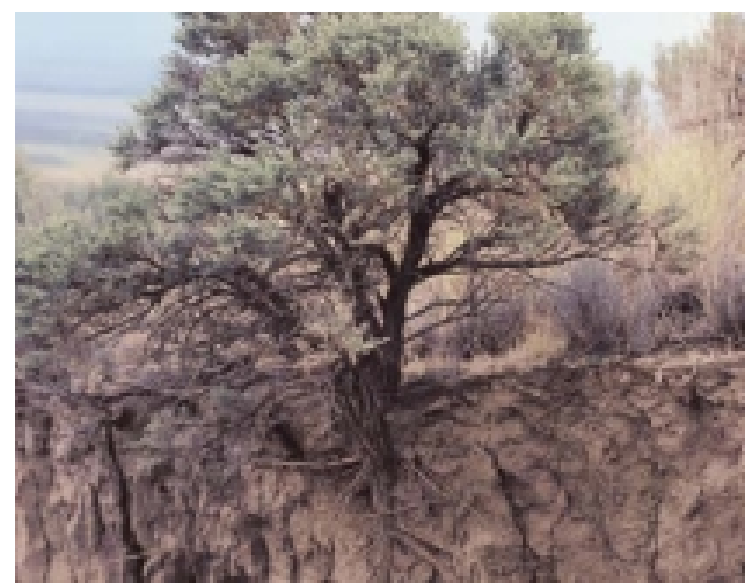

Big sagebrush is the most common shrub component of shrub-steppe vegetation on the site. 


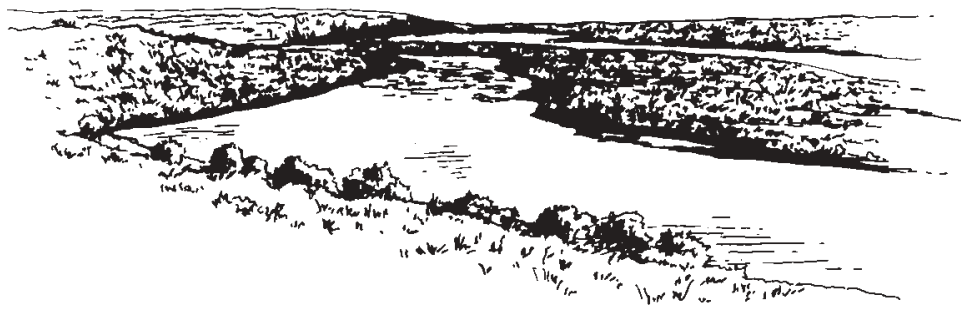

\section{Ecological \\ Compliance}

The policies of DOE's Richland Operations Office require that all projects having the potential to adversely affect biological resources have an ecological compliance review performed before the project begins. This review ensures that DOE is in compliance with the Endangered Species Act and the Migratory Bird Treaty Act.

Ecological compliance reviews also ensure that other significant resources such as Washington State listed species of concern, wetlands, and native shrubsteppe habitats are adequately considered during the project planning process.

Since many projects on the site occur during times of the year when plants are not growing, and the plants are difficult to identify or evaluate, each operational area is surveyed each spring. These baseline surveys provide information about habitat types and species inventories and abundance that can be used throughout the year to assess potential project impacts.

A total of 98 ecological compliance reviews were performed during 2000 in support of general Hanford activities. An additional 63 reviews were performed during 2000 in support of environmental restoration activities. The total number of reviews prepared in 2000 (161) was slightly less than in previous years.

Additional and more detailed information about the Hanford Site ecosystem can be viewed on the Ecosystem Monitoring Project web page

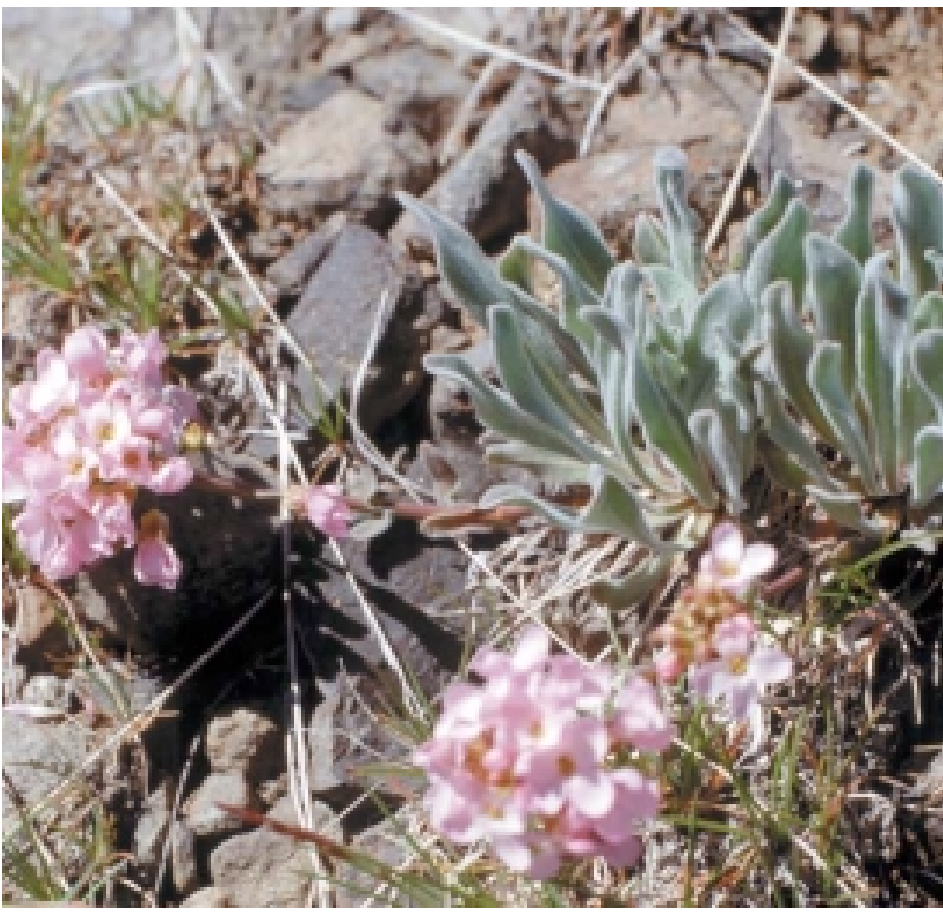

Federal laws provide legal protection for some plant and animal species of concern.

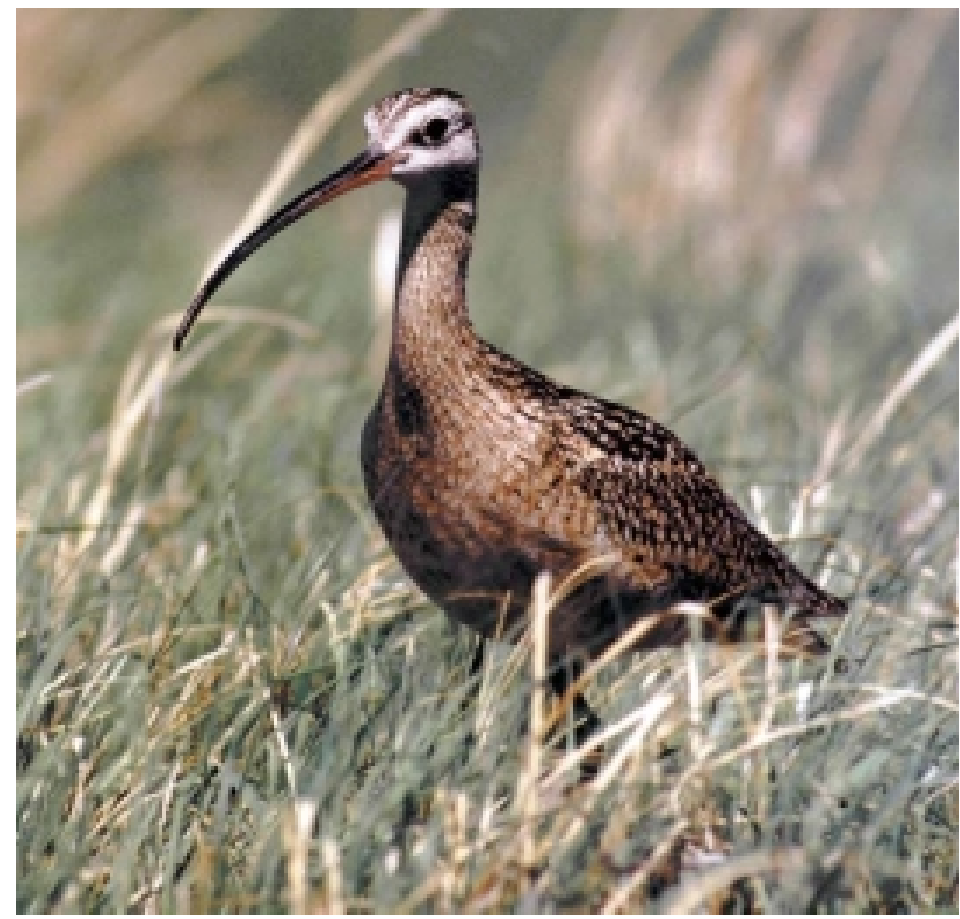

The long-billed curlew is a state monitor species in Washington. The curlew is found on the site from early spring to mid-summer. at www.pnl.gov/ecology/ecosystem. 


\section{Cultural Resources}

The DOE Richland Operations Office has maintained a monitoring program since 1987 to determine the impact of its policies on cultural resources and to safeguard cultural resources from adverse effects associated with natural processes or unauthorized excavation and collection.

Monitoring conducted during 2000 focused on Locke Island erosion, archaeological sites affected by visitors or nature, historic buildings, and places with Native American burials.

Locke Island, located in the Hanford Reach, has sustained loss due to erosion along its eastern shoreline that has affected archaeological deposits. Surveys in 2000 recorded erosional losses of up to 2.1 meters (6.9 feet) as measured perpendicularly from the Columbia River.

Ninety-six archaeological sites were monitored in 2000 to gather data associated with recreational use, visitor impact, and natural weathering processes.

Places with cemeteries or known human remains were monitored to document baseline conditions, determine whether erosion had exposed human remains, and monitor for violations of federal laws.

During 2000, 113 cultural resource reviews were requested and conducted on the Hanford Site to comply with the National Historic Preservation Act. Also during 2000, DOE was in the process of evaluating the feasibility of retaining various historic structures on the Hanford Site, including Bruggemann's Warehouse, the only cobblestone structure remaining on the Hanford Site, and White Bluffs Bank, both pre-Manhattan Project buildings. An assessment of the structural condition of both buildings was completed.

Public involvement is an important component of cultural resource management. To facilitate involvement, DOE developed mechanisms that allowed the public access to cultural resources infor-

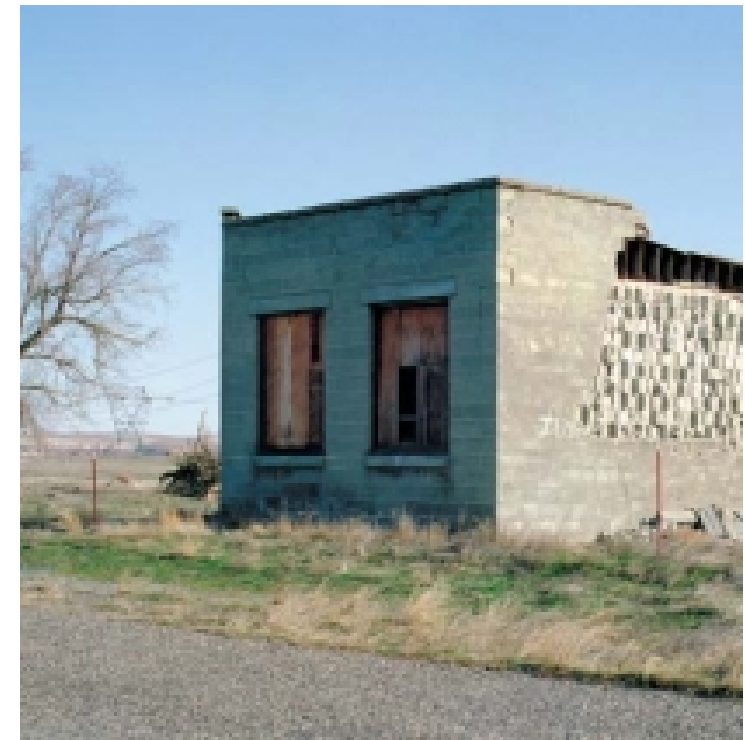

Efforts are underway to stabilize the old White Bluffs Bank building, which was constructed in 1907.

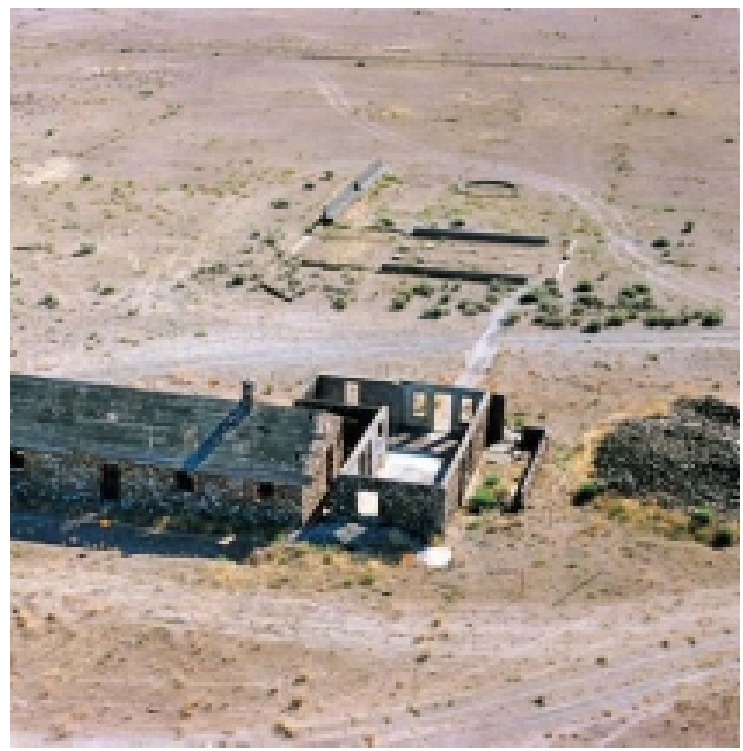

Bruggemann's warehouse is located along the Columbia River, upstream from the B/C Reactor, near the Vernita Bridge.

mation and to comment and make recommendations about the management of cultural resources on the Hanford Site. Native American involvement included the completion of several surveys, construction monitoring, and monthly meetings on cultural resource issues. 


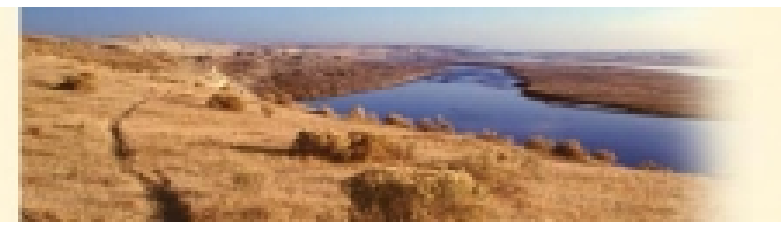

Stakeholder and Tribal Involvement

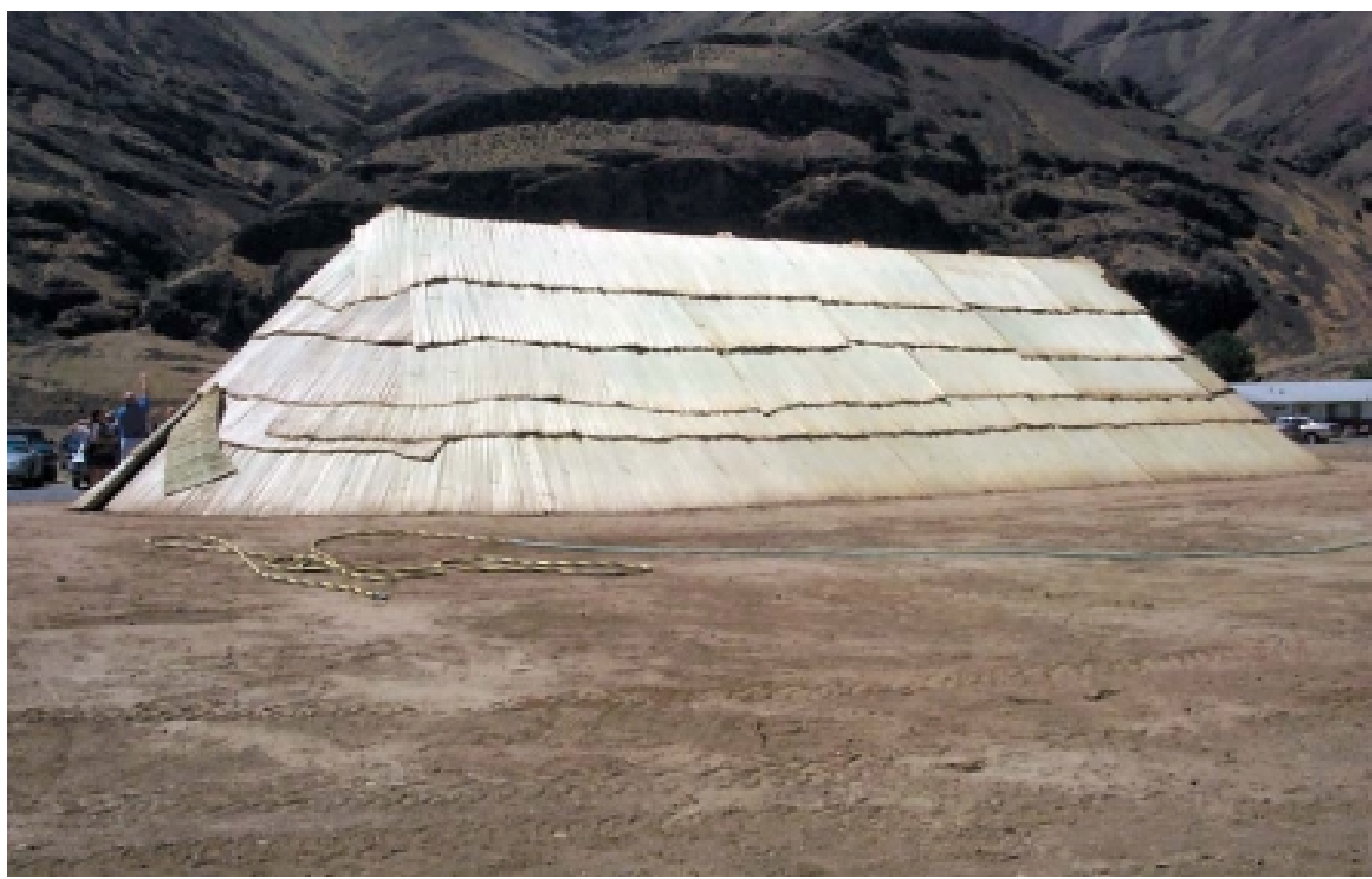

In July 2000, the Wanapum People built a tule mat lodge at Priest Rapids of the long green stems of tule, a wetland plant, harvested from the slow current marshes along the Columbia River.

Many entities have a role in DOE's mission of environmental restoration, waste management, and protection of the Columbia River at the Hanford Site. Stakeholders include federal, state, and local regulatory agencies; environmental groups; regional communities and governments; and the public. Indian tribes and nations also have a special and unique involvement with the Hanford Site.

Federal, state, and local regulatory agencies are responsible for monitoring and enforcing compliance with applicable environmental regulations at the site. Major agencies include the EPA, Washington State Department of Ecology, Washington State Department of Health, and Benton Clean Air Authority. The Hanford Natural Resource Trustee Council is another stakeholder. This council comprises federal trustees for Hanford natural resources, including the U.S. Fish and Wildlife Service, Bureau of Land Management, and National Oceanic and Atmospheric Administration. Local Indian tribes also are members of the council. Its primary purpose is to facilitate coordination and cooperation of member trustees in their efforts to mitigate impacts to natural resources that result from either hazardous substances releases within the site or remediation of those releases. 


\section{The Role of Indian Tribes}

The Hanford Site is located on land ceded to the United States government by the Yakama Nation and the Confederated Tribes of the Umatilla Indian Reservation in the Treaties of 1855 . These two tribes, as well as the Nez Perce Tribe, have treaty fishing rights on portions of the Columbia River. The tribes reserve the right to fish "at all usual and accustomed places" and the privilege to hunt, gather roots and berries, and pasture horses and cattle on open and unclaimed land on the site.

The Wanapum people are not a federally recognized tribe, but have historic ties

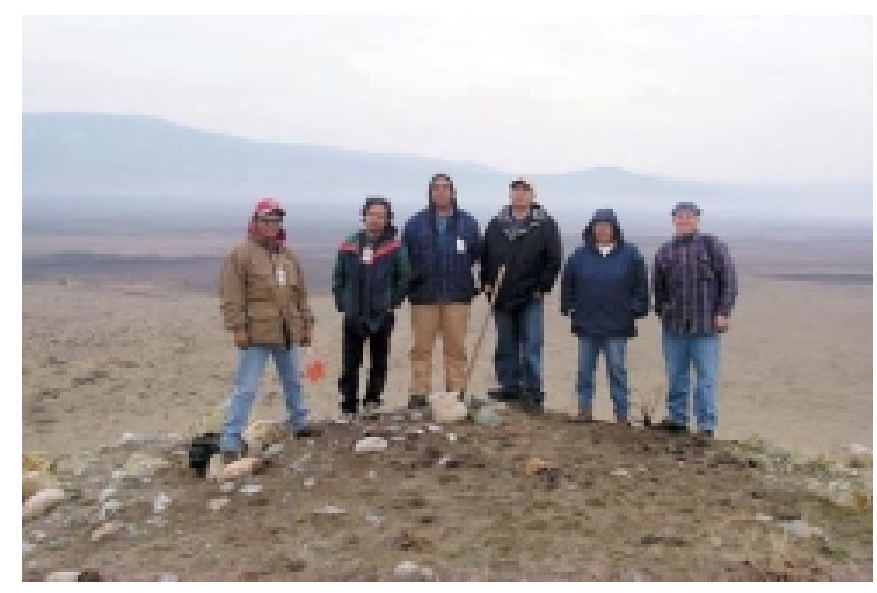

Members of the tribal nations joined DOE scientists after the June 2000 wildfire to assess damage from the fire and firefighting activities to known archeological sites. and and Tribal Government Working Group, the Hanford Natural Resources Trustee Council, the Hanford Site Groundwater/Vadose Zone Integration Project, the Hanford Cultural Resources Program, and provide review and comments on draft documents. Both the Wanapum People and the Confederated Tribes of the Colville Reservation are also provided an opportunity to comment on appropriatedocuments and participate in cultural resource management activities.

The DOE American Indian and Alaska Native Tribal Government Policy guides DOE's interactions with tribes for Hanford to the Hanford Site as do the Confederated Tribes of the Colville Reservation, whose members are descendants of people who used the area now known as the Hanford Site.

The site's environment supports a number of Native American foods and medicines and contains sacred places important to tribal cultures. The tribes hope to use these resources in the future and want to ensure the Hanford environment is clean and healthy.

American Indian Tribal governments have a special and unique legal and political relationship with the governments of the United States, defined by history, treaties, statutes, court decisions, and the U.S. Constitution. In recognition of this relationship, DOE and each tribe interact and consult directly. Tribal government representatives from the Yakama Nation, Confederated Tribes of theUmatilla Indian Reservation, and the Nez Perce Tribe participate in DOE-supported groups such as the State plans and activities. It states, among other things, "The Department will consult with any American Indian or Alaska Native tribal government with regard to any property to which that tribe attaches religious or cultural importance which might be affected by a DOE action."

DOE provides financial assistance through cooperative agreements with the Yakama Nation, the Confederated Tribes of the Umatilla Indian Reservation, and the Nez Perce Tribe to support their involvement in environmental management activities of the Hanford Site.

During 2000, two Wanapum members continued assisting with cultural resource surveys, site form preparation, records management, and equipment use. Interviews were conducted with Wanapum elders about sites that have traditional significance on the Hanford site. 


\section{Public Participation}

Citizens of the state of Washington and neighboring states may influence Hanford Site cleanup decisions through public participation activities. The public is provided opportunities to contribute their input and influence decisions through many forums, including Hanford Advisory Board meetings, Tri-Party Agreement activities, National Environmental Policy Act public meetings covering various environmental impact statements and environmental assessments, and many other outreach programs.

The Tri-Party Agreement provides a means for Hanford to become compliant with environmental regulatory requirements.

The Community Relations Plan, a companion to the

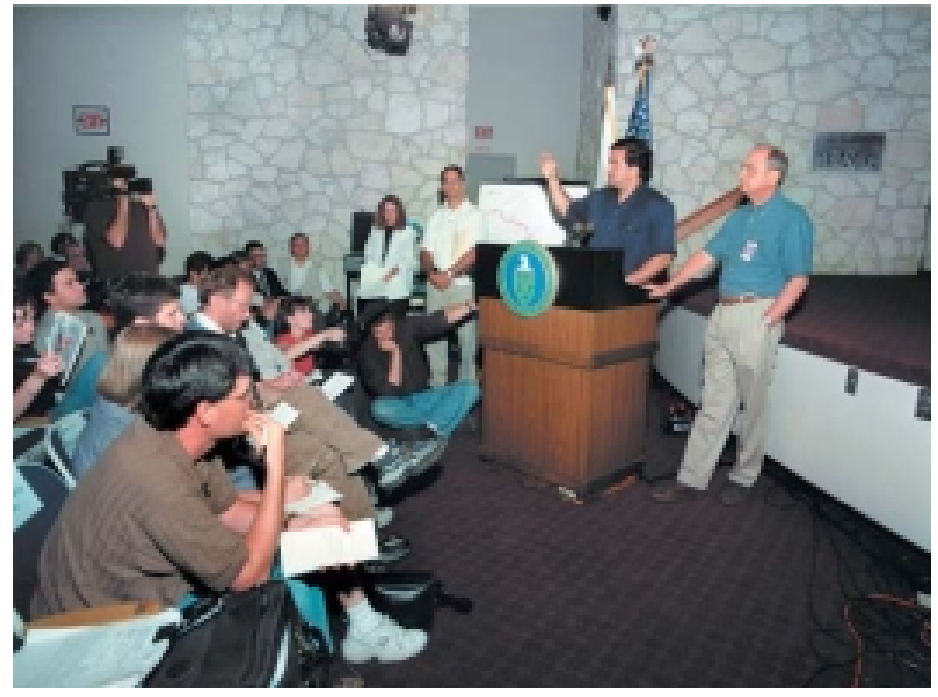

Citizens of the state of Washington and neighboring states may influence Hanford Site cleanup decisions through public participation activities and public meetings. kept current. The mailing list is also used to send topic-specific information to those people who have requested it.

To apprise the public of upcoming opportunities for public participation, DOE publishes the bimonthly Hanford Update, which summarizes all ongoing and upcoming Tri-Party Agreement public involvement activities. In addition, the Hanford Happenings calendar highlights Tri-Party Agreement meetings and comment periods and is distributed monthly to the entire mailing list.

Most of Hanford's stakeholders reside in Washington, Oregon, and Idaho. To allow them better access to up-to-date Hanford Site information, four information repositories have been established. They are located in Richland, Seattle, and Spokane, Washington, and Portland, Oregon.

The three parties respond to questions via a toll-free telephone line (800-321-2008). Members of the public can request information about any public participation activity and receive a response by calling the Office of Intergovernmental, Public, and Institutional Affairs (DOE Richland Operations Office) at (509) 376-7501. Also, there is a calendar of public involvement opportunities on the Internet: www.hanford.gov/ calendar/. 


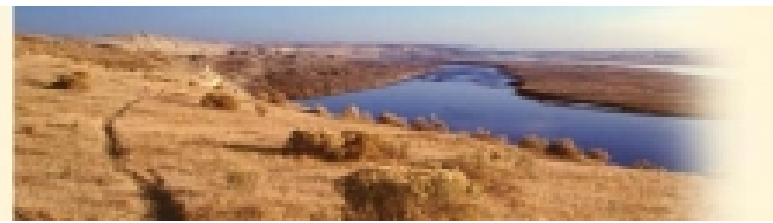

Index

100 Areas

air, 23, 29

description, 5

fish, 28

groundwater, 31, 33, $35 \mathrm{~T}$

sagebrush die-off, 41

surface water, 25, 26

vadose zone, 34

200 Areas

air, 23

description, $5,8 F$

groundwater, 31, 32, 33, $35 \mathrm{~T}$

vadose zone, 33, 34

300 Area

air, 23, 24

Columbia River, 25

description, 5

groundwater, 33

400 Area, 5, 23, 31

600 Area

air, 23

description, 5

groundwater, 31, 32, 33

1100 Area, 5

air monitoring, 23-24, 30

American Indian Religious Freedom Act, $18 \mathrm{~T}$

animals. See wildlife and fish

anions, 25, 26

Antiquities Act, $18 \mathrm{~T}$

Archaeological and Historic Preservation Act, $18 \mathrm{~T}$

archaeological sites, 43

Arid Lands Ecology Reserve, 5, 15

arsenic, 26

avocets, 29

\section{B}

bacteria, 19

bald eagles, 3, 39, 39F

Bechtel-Washington, 11

biodiversity inventory, 3, 41

See also plants

birds

list, 3

monitoring, 39, 39F, 42F

radioactive contamination, 26, 28-29
Borrow Pit 24, 15

Bruggemann's warehouse, 43, 43F

budget for Hanford Site, 6

buildings

air monitoring, 23

historic structures, 18T, 37, 43, 43F

Plutonium Finishing Plant, 33

reactors, $7,7 F, 15,15 F, 21$

vitrification plant, $8 \mathrm{~F}, 11$

waste management, 12-14, 34

wildfire, 30, 30F

burial grounds

purpose, 6, 13

tritium, 19, 31, 34

carbon-14, 31, 32

carbon tetrachloride, 31, 32, 33, 34

carp, 28

cars, 20F, 40F

cemeteries, 43

Central Waste Complex, 13, 13F

cesium-137, 27, 28, 31, 32

chinook salmon, $3,16 F, 32 F, 38,38 F$

chloride, 26

chloroform, 32, 33

chromium, 26, 32, 33

clastic dikes, 33

Clean Air Act, $17 T$

Clean Water Act, 17T

climate, 37, 38

cobalt-60, 31, 32

Cold Creek Valley, 37F

coliform bacteria, 19

Columbia River

contamination, 2F, 25-26, 25F

description, 2, 5, 16F

Locke Island, 43

shoreline radiation, 29

See also surface water and sediment

community-based monitoring, 24, 29

Comprehensive Environmental Response, Compensation, and Liability Act, 17T, 18

contractors, 6

cribs and groundwater, 32, 33

cultural resources, 18T, 30, 37, 43

curlew, $42 \mathrm{~F}$

cyanide, 32, 33 


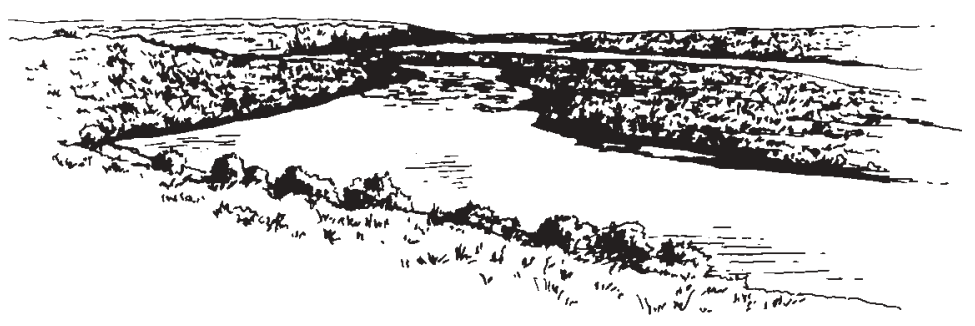

D

decontaminating and decommissioning, 15 deer, mule, 28-29, 29F, 40, 40F

double-shell tanks. See tanks, underground

DR Reactor, 15

drinking water, 18T, 19, 25, 27, 31

dust storms, 38

ב

ecological compliance review, 42

Ecosystem Monitoring Project, 38-42

effluents, liquid, 6, 12, 14

See also tanks, underground

elk, Rocky Mountain, 3, 29, 40, 40F

emergency occurrence, 19

Emergency Planning and Community Right-to-Know Act, $17 T$

Endangered Species Act, 3, 18T, 42

Energy Northwest, 31, 34

Environmental Management Science Program, 33 environmental occurrences, 19

Environmental Restoration Disposal Facility, 14, 34

evaporator, 242-A, 12, 12F

external radiation, 29

F Reactor, 15, 15F

fall chinook salmon, 3, 16F, 32F, 38, 38F

Fast Flux Test Facility, 7, 7F, 21

Federal Insecticide, Fungicide, and Rodenticide Act, $18 \mathrm{~T}$

ferruginous hawks, 39, 39F

fish, 3, 16F, 28, 32F, 38, 38F

Fitzner/Eberhardt Arid Lands Ecology Reserve, 5, 15

flies, black, 29

fluoride, 32, 33

food and farm products, 27-28, 30

See also irrigation water

c

grapes and tritium, 28

groundwater

contamination, 19, 31-33

monitoring, 22, 31

treatment, $35 \mathrm{~T}$

See also vadose zone
H

Hanford Federal Facility Agreement and Consent Order, 8, 18-19, 46

Hanford Formation, 34

Hanford Meteorology Station, 38

Hanford Natural Resource Trustee council, 44

Hanford Reach National Monument, 2, 3, 5, 5F, 16F

Hanford Site description, 2-7

Hanford Townsite, 25

hawks, 39, 39F

Highway 24 Command Wildfire, 15, 19, 19F, 30, 30F, $45 \mathrm{~F}$

Historic Sites Buildings and Antiquities Act, 18T

historic structures, 18T, 37, 43, 43F

history of the Hanford Site, 3, 6

hops, 28

Indian tribes, 18T, 43, 44, 45

insects, 3, 29

iodine-129, 25, 28, 31, 32

irrigation water, 25, 26, 27

land use near the Hanford Site, 2

Liquid Effluent Retention Facility, 12, 12F

liquid waste, $6,12,14$

See also tanks, underground

location of Hanford Site, 4F, 6

Locke Island, 43

lodge built by Native Americans, $44 \mathrm{~F}$

\section{M}

maximally exposed individual, 20, 21

metals, 25, 26

meteorology, 37, 38

Meteorology Station, Hanford, 38

Migratory Bird Treaty Act, 18T, 42

milk samples, $27 \mathrm{~F}$

mission of Hanford Site, 6, 7

mixed waste from offsite, 9

monitoring, environmental, 22, 22F

See also specific media

mule deer, 28-29, 29F, 40, 40F

N

National Environmental Policy Act, $18 T$

National Historic Preservation Act, 18T, 43 
Native American Graves Protection and Repatriation Act, $18 \mathrm{~T}$

Native Americans, 18T, 43, 44, 45

Natural Resource Trustee council, 44

naval reactors, 13

near-facility monitoring, 23

nitrate

groundwater, 31, 32, 33

surface water, 25,26

○

occurrences, environmental, 19

Office of River Protection, 10, 11

Old Hanford Townsite, 25

passive neutron tool, 35

Piper's daisy, 41, 41F

plants

biodiversity, 3, 41

crops, 27-28, 30

wildfire, 15, 30

plutonium, 30, 31

Plutonium Finishing Plant, 33

Pollution Prevention Program, 15

ponds on Hanford Site, 26-27, 33-34

potassium-40, 28

public involvement, 43, 46

quality assurance, $36,36 \mathrm{~F}$

\section{R}

radioactive materials

air, 23-24, 29, 30

animals, 26, 28-29

drinking water, 27

food, 27-28, 30

groundwater, 19, 31-33

occurrences, 19, 30

potential doses, 20-21

production, 6

soil, 34

surface water, 25-27

radioactive waste management, 9-13

Rattlesnake Mountain, 6

reactors

decommissioning, 7, 15 radioactive contamination, 21,32

submarines, 13

recycling at Hanford, 15

regulations, 3, 8, 16-19, 42, 43, 46

Resource Conservation and Recovery Act, 17T, 18

restoring waste sites, $14-15$

Richland North Area, 5

Richland Pumphouse, 25

Ringold Formation, 34

rivers. See Columbia River

Rocky Mountain elk, 3, 29, 40, 40F

\section{$S$}

Safe Drinking Water Act, $18 \mathrm{~T}$

sagebrush, 15, 41, $41 \mathrm{~F}$

salmon, 3, 16F, 32F, 38, 38F

sediment. See surface water and sediment

single-shell tanks. See tanks, underground

soil, 14, 29, 30, 34

soil vapor extraction, $34,35 \mathrm{~T}$

solid waste

environmental impacts, 19, 31, 34

preparation and disposal, 13

production, 6, 9

Solid Waste Landfill, 34

spectral gamma logging tool, $35,35 \mathrm{~F}$

springs, Columbia River, 26

stakeholders, 44, 46

See also Native Americans

strontium-90

food and farm products, 27, 28

groundwater, 31, 32

surface water and sediment, 25, 26

wildfire, 30

wildlife, 28, 29

sulfate, 26

surface water and sediment

description, 2, 3, 5, 16F

fish, 3, 16F, 28, 32F, 38, 38F

radioactive contamination, 25-27, 29

Swainson's hawks, 39, 39F

tanks, underground

2000 activities, 9-11

construction, 7F

radioactive contamination, 32,33

treatment, $8 \mathrm{~F}, 10,11,11 \mathrm{~F}, 12$

technetium-99, 31, 32

temperature at Hanford Site, 38

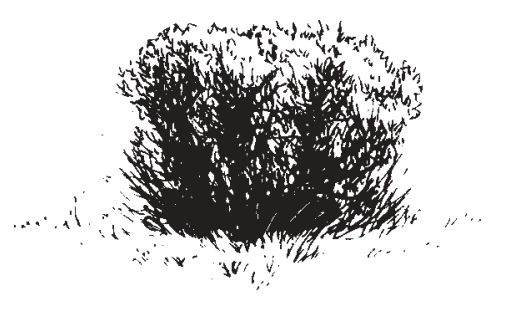

Summary 


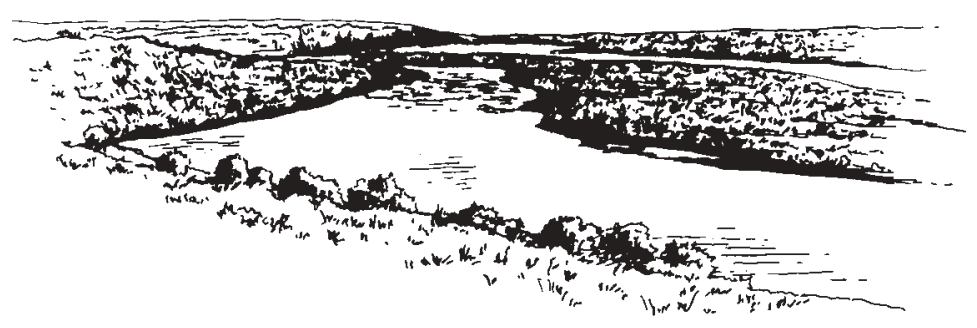

Toxic Substances Control Act, $18 \mathrm{~T}$

Treated Effluent Disposal Facilities, 12, 12F

trenches

purpose, 6,13

tritium, 19, 31, 34

Tri-Party Agreement, 8, 18-19

trichloroethene, 31, 32, 33

tritium

air, 24

food, 28

groundwater, 19, 31

soil, 34

surface water and sediment, 25, 26

tule, $44 \mathrm{~F}$

U

uranium

groundwater, 31, 32

surface water and sediment, 25, 26, 27, 29

wildfire, 30

U.S. Department of Energy

Office of River Protection, 10, 11

radiological dose limit, 20, 21

Tri-Party Agreement, 8, 18

U.S. Environmental Protection Agency, 8, 18

U.S. Fish and Wildlife Service, 2, 5

\section{V}

vadose zone, 31, 33-35

See also groundwater

vegetation

biodiversity, 3, 41

crops, 27-28, 30

wildfire, 15,30

vitrification, $8 \mathrm{~F}, 10,11,11 \mathrm{~F}$

W

Wanapum People, 44F, 45

Washington State Department of Ecology, 8, 18

waste management, 9-13, 19

Waste Receiving and Processing Facility, 13, 13F

wastewater, 12

West Lake, 3, 27, 29

White Bluffs, 1F, 34

White Bluffs Bank, 43, 43F

wildfire, 15, 19, 19F, 30, 30F, 45F

wildlife and fish

on Hanford Site, 3

monitoring, 37, 38-40, 42, 42F

radioactive contamination, 26, 28-29, 32F

regulations, 3, 18T, 42

spawning, 3, 16F, 32F

wind speed, 38

wine and tritium, 28

workers on Hanford Site, 6, 21

Y

yellowcress, persistent sepal, 41, 41F

Pages containing photographs and figures are denoted with an $\mathrm{F}$ after the page number. Pages containing tables are denoted by $\mathrm{T}$. 


\section{Can We Make This Summary More Useful for You?}

We want this summary to be easy to read and useful. To help continue this effort, please take a few minutes to let us know if the summary meets your needs. Then tear out this page, and mail or fax it to Bill Hanf, Pacific Northwest National Laboratory, P.O. Box 999, MSIN K6-75, Richland, WA 99352. Phone: (509) 376-8264; Fax: (509) 376-2210

\section{How do you use the information in this summary?}

$\square \quad$ To become more familiar with Hanford monitoring

- To help me make a decision about moving to the Tri-Cities

$\square$ To send to others outside the Tri-City area

To prepare for public meetings on Hanford cleanup

$\square \quad$ Other (please explain)

2. What parts of the summary do you use?

- Hanford Site overview/mission

$\square$ Quality assurance

$\square$ Site management

$\square \quad$ Regulatory oversight

Environmental compliance

$\square$ Environmental monitoring

$\square$ Current issues and actions

Potential radiation doses from operations Hanford environmental programs

3. Does this guide contain

enough detail?

too much detail?

too little detail?

Comment:

4. If you could change this guide to make it more readable and useful to you, what would you change?

5. What is your affiliation?

$\square$ Hanford Site contractor

State agency

Public interest group

Member of Native American Nation

University

$\begin{array}{ll}\square & \text { DOE } \\ \square & \text { Federal agency } \\ \square & \text { Member of the public } \\ \square & \text { Local government } \\ \square & \text { Industry }\end{array}$

6. Other Comments?

Thank you! 


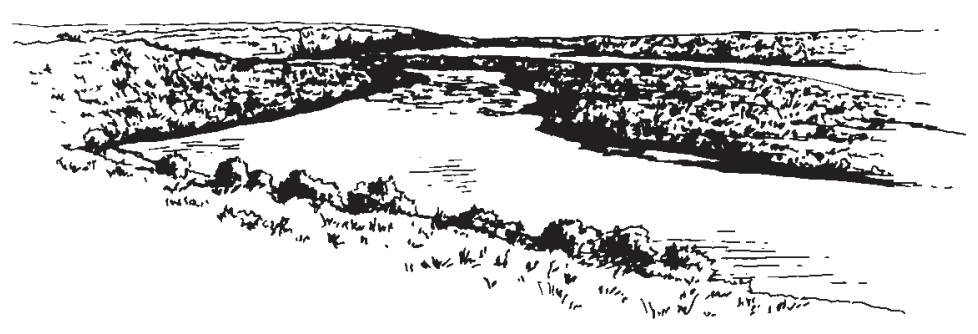

\section{Acknowledgments}

We thank K. R. Price, Pacific Northwest National Laboratory, for providing the historical information on Hanford Site operations; Jane Winslow, WinSome Design, Inc., for designing the booklet; Melanie HessRobinson, WinSome Design, Inc., for landscape illustrations; and Kathy Neiderhiser, Pacific Northwest National Laboratory, for providing text processing support. We also thank the following individuals for use of their photographs: Andrea Currie, Janelle Downs, Laurie Hale, John Thorpe, and Brett Tiller. 